
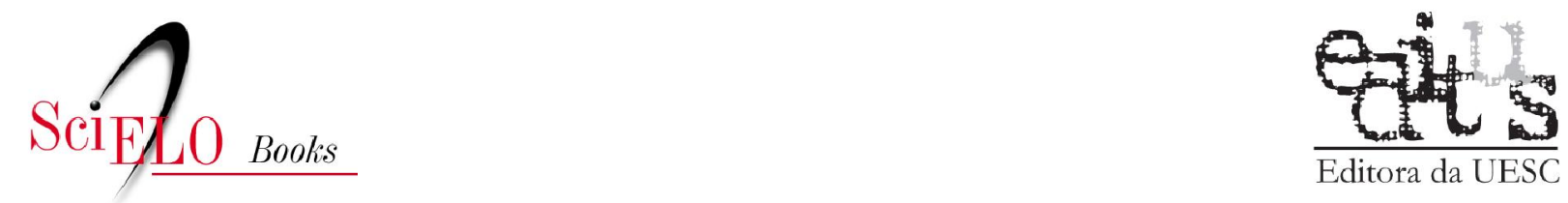

Editora da UESC

\title{
Recuperação ambiental Mata Atlântica
}

\author{
Danilo Sette de Almeida
}

SciELO Books / SciELO Livros / SciELO Libros

ALMEIDA, DS. Recuperação ambiental da Mata Atlântica [online].3rd ed. rev. and enl. Ilhéus, BA: Editus, 2016, 200 p. ISBN 978-85-7455-440-2. Available from SciELO Books

$<\underline{\text { http://books.scielo.org }>\text {. }}$

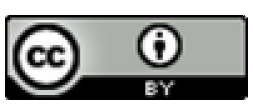

All the contents of this work, except where otherwise noted, is licensed under a Creative Commons Attribution 4.0 International license.

Todo o conteúdo deste trabalho, exceto quando houver ressalva, é publicado sob a licença Creative Commons Atribição 4.0.

Todo el contenido de esta obra, excepto donde se indique lo contrario, está bajo licencia de la licencia Creative Commons Reconocimento 4.0. 

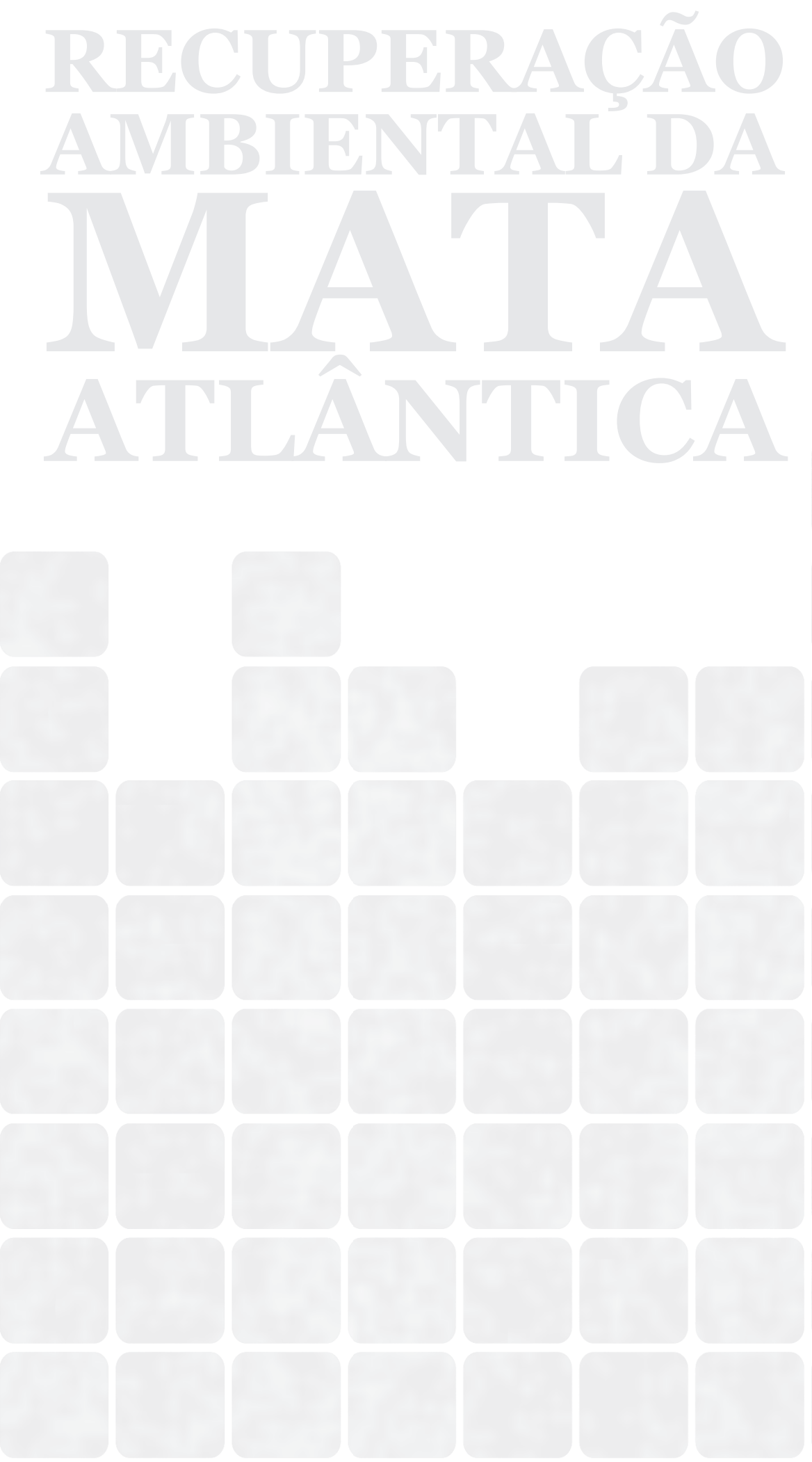


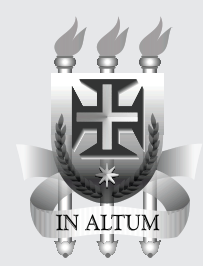

\section{Universidade Estadual de Santa Cruz}

GOVERNO DO ESTADO DA BAHIA

JAQUES WAGNER - Governador

SECRETARIA DE EDUCAÇÃO

Osvaldo Barreto Filho - Secretário

UNIVERSIDADE ESTADUAL DE SANTA CRUZ

Adélia Maria Carvalho de Melo Pinheiro - Reitora

Evandro Sena Freire - Vice-Reitor

\section{DIRETORA DA EDITUS}

Rita Virginia Alves Santos Argollo

Conselho Editorial:

Rita Virginia Alves Santos Argollo - Presidente

Andréa de Azevedo Morégula

André Luiz Rosa Ribeiro

Adriana dos Santos Reis Lemos

Dorival de Freitas

Evandro Sena Freire

Francisco Mendes Costa

José Montival Alencar Junior

Lurdes Bertol Rocha

Maria Laura de Oliveira Gomes

Marileide dos Santos de Oliveira

Raimunda Alves Moreira de Assis

Roseanne Montargil Rocha

Silvia Maria Santos Carvalho 


\section{Danilo Sette de Almeida}

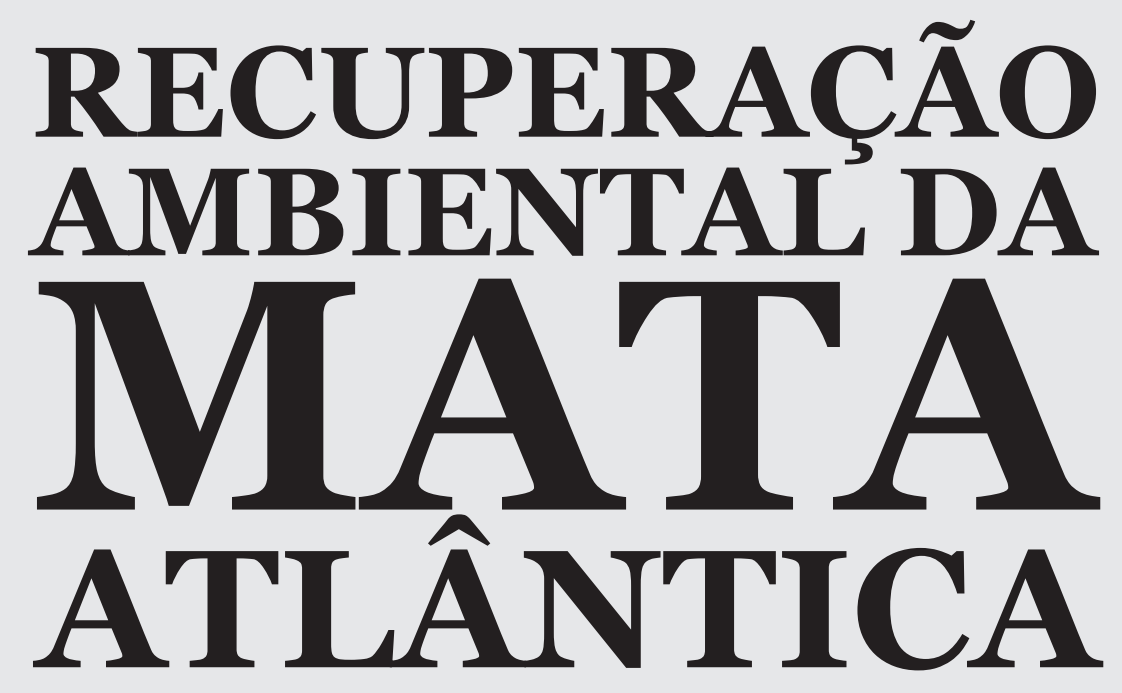

$3^{\mathbf{a}}$ Edição
Revista e ampliada

Ilhéus-Bahia

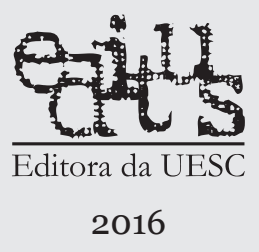


Copyright (C)20oo by Danilo SetTe De Almeida

$1^{\mathrm{a}}$ edição 2000

$2^{\mathrm{a}}$ edição 2006

$1^{\mathrm{a}}$ reimpressão 2013

$3^{\mathrm{a}}$ edição 2016

Direitos desta edição reservados à

EDITUS - EDITORA DA UESC

A reprodução não autorizada desta publicação, por qualquer meio, seja total ou parcial, constitui violação da Lei n ${ }^{\circ}$ 9.610/98.

Depósito legal na Biblioteca Nacional,

conforme Lei no 10.994 , de 14 de dezembro de 2004.

\section{PROJETO GRÁFICO E CAPA}

Deise Francis Krause

REVISÃO

Maria Luiza Nora

Roberto Santos de Carvalho

Sylvia Maria Campos Teixeira

Dados Internacionais de Catalogação na Publicação (CIP)

A447 Almeida, Danilo Sette de.

Recuperação ambiental da mata atlântica / Danilo Sette de Almeida. - 3. ed. rev. e ampl. - Ilhéus : Editus, 2016. 200p. : il.

ISBN: 978-85-7455-406-8

Bibliografia : p. 189-200.

1.Mata atlântica. 2. Florestas - Conservação - Brasil. 3. Proteção ambiental - Brasil. I. Título.

CDD -634.977

EDITUS - EDITORA DA UESC

Universidade Estadual de Santa Cruz

Rodovia Jorge Amado, km 16 - 45662-90o - Ilhéus, Bahia, Brasil

Tel.: (73) 3680-5028

www.uesc.br/editora

editus@uesc.br

EDITORA FILIADA À

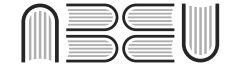

Associação Brasileira das Editoras Universitárias 


\section{SUMÁRIO}

2 HISTÓRICO E TENDÊNCIAS ATUAIS DA RECUPERAÇÃO AMBIENTAL

3 CONCEITOS BÁSICOS

3.1 Alguns termos técnicos aplicados à recuperação ambiental........25

\section{LEGISLAÇÃO BÁSICA APLICADA À} RECUPERAÇÃO AMBIENTAL

5 FLORESTA ATLÂNTICA

5.1 Conceituação e distribuição

\section{ALGUNS PRINCÍPIOS DE SUCESSÃO NATURAL} APLICADOS AO PROCESSO DE RECUPERAÇÃO

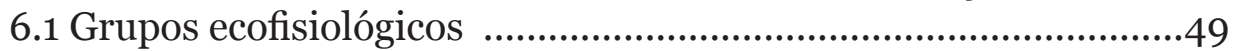

6.2 Composição florística e fitossociológica.........................................58

6.3 Polinização e dispersão de sementes ..........................................59

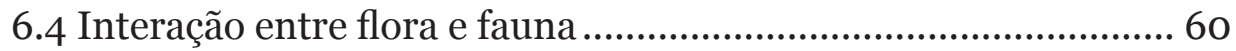

6.5 Mecanismos de sucessão e regeneração natural.............................64

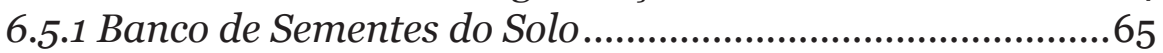

6.5.2 Banco de plântulas ..............................................................69

6.5.3 Chuva de sementes................................................................69

6.5.4 Rebrota de cepas................................................................70

6.6 Aplicação de princípios da sucessão ecológica na restauração .................................................................................70

6.7 Espécies exóticas invasoras e suas interferências na restauração ecológica ................................................................. 71

6.8 Considerações sobre aspectos genéticos.......................................72 
7 DIAGNÓSTICOS AMBIENTAIS .............................................. 77

7.1 Identificação e avaliação da série histórica de impactos..............79

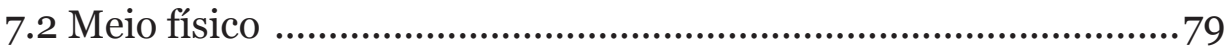

7.2.1 Aspectos climáticos .............................................................79

7.2.2 Levantamentos edáficos .................................................. 80

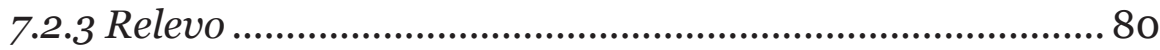

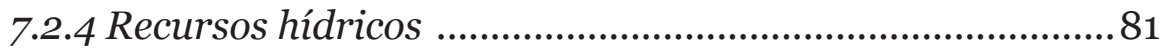

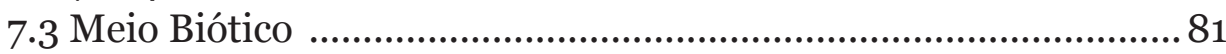

7.3.1 Estudos florísticos e fitossociológicos .................................. 81

7.3.2 Reconhecimento da vegetação pioneira ..............................83

7.3.3 Banco de sementes e de plântulas .........................................83

7.3.4 Levantamentos faunísticos................................................ 84

7.4 Ambiente degradado - fatores limitantes.....................................85

7.5 Diagnósticos no nível de paisagem .............................................. 86

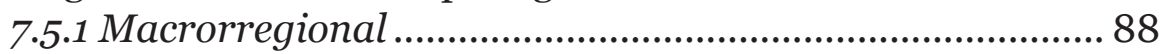

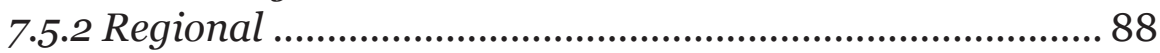

7.5.3 Local degradado .............................................................. 89

\section{PONTOS BÁSICOS PARA DESENVOLVIMENTO DE} PROJETOS DE RESTAURAÇÃO ECOLÓGICA ………......... 91

8.1 Seleção de espécies .......................................................................93

8.2 Inserção na paisagem, interação com vizinhança .........................95

8.3 Princípios da Sucessão Ecológica...............................................96

8.4 Métodos biológicos de recuperação de áreas degradadas ............96

9 MODELOS DE RECUPERAÇÃO AMBIENTAL …….............99

9.1 Alguns modelos de recuperação ambiental................................ 101

9.1.1 Condução da regeneração natural ....................................104

9.1.2 Plantio de mudas..................................................................105

9.1.3 Recuperação com espécies pioneiras ................................107

9.1.4 Formação de ilhas de diversidade (Nucleação) ................108

9.1.5 Modelo sucessional - plantio em linhas alternadas .........109

9.1.6 Modelo sucessional - plantios em módulos..........................113

9.1.7 Indução da chuva de sementes ............................................113

9.1.8 Plantio inicial de mudas e posterior semeio........................113

9.1.9 Plantio de estacas diretamente no campo ......................... 114

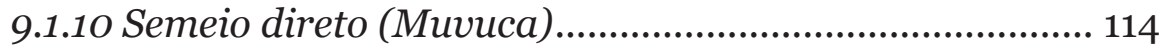

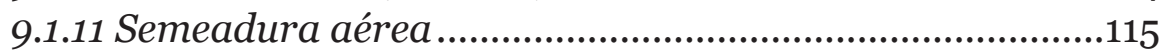

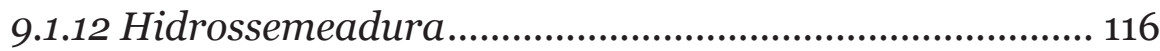

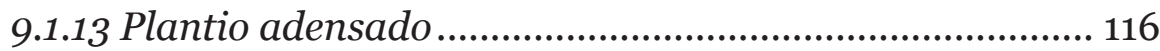


9.1.14 Plantio de leguminosas ..................................................117

9.1.15 Recuperação com uso de espécies frutíferas .................... 118

9.1.16 Ampliação Ecológica de Fragmentos Florestais ............ 118

9.1.17 Recuperação ambiental de ecossistemas com invasão de espécies exóticas.......................................................... 119

9.2 Estratégias auxiliares de apoio à recuperação ambiental.......... 119

9.2.1 Utilização de matéria orgânica........................................ 119

9.2.2 Uso da manta orgânica florestal (serrapilheira) .............121

9.2.3 Utilização de telas naturais ............................................... 123

9.2.4 Aplicação de organismos e microrganismos .....................123

9.2.5 Colocação de poleiros artificiais .........................................124

9.3 Desenho de sistemas florestais de uso múltiplo .......................... 125

9.3.1 Seleção de espécies .............................................................126

9.3.2 Modelagem ……............................................................. 127

9.4 Modelos de enriquecimento de fragmentos florestais.................131

9.5 Avaliação dos modelos de recuperação ambiental ......................132

9.5.1 Avaliação ambiental ......................................................... 133

9.5.2 Componente econômico.......................................................134

9.5.3 Desempenho social ........................................................... 136

9.5.4 Aspectos legais ..................................................................... 137

10 PLANO DE RECUPERAÇÃo DE ÁREAS

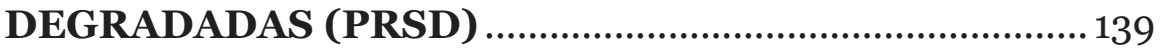

10.1 Definições gerais ..................................................................... 141

10.2 Procedimentos e métodos para elaboração de PRAD............... 142

10.2.1 Considerações e planejamento inicial ............................142

10.2.2 Identificação dos agentes de degradação......................144

10.2.3 Delimitação das áreas de influência ...............................144

10.2.4 Avaliação do grau de degradação .................................144

10.3 Elaboração do projeto de recuperação - roteiro básico ............. 144

10.3.1 Parte introdutória .............................................................. 144

10.3.2 Caracterização do Empreendimento ............................. 145

10.4 Diagnósticos Ambientais ............................................................. 146

10.4.1 Caracterização do meio físico.......................................147

10.4.2 Caracterização do meio biótico ...................................... 147

10.4.3 Caracterização do meio socioeconômico ........................148

10.5 Plano de recuperação das áreas degradadas

(Reconstituição do meio ambiente) ..........................................148

10.6 Avaliação de PRAD ...................................................................... 153

10.7 Estudos de caso sobre algumas situações específicas ............... 153

10.7.1 Áreas degradadas por mineração ................................. 153 
10.7.2 Florestas ciliares ....

10.7.3 Taludes de grandes declives em margens de rodovias ... 156

10.7.4 Erosão em sulco ou voçorocas

10.7.5 Ecossistema degradado pela presença de espécies exóticas invasoras.

\section{MANUTENÇÃO DE PROJETOS DE}

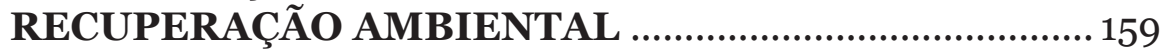

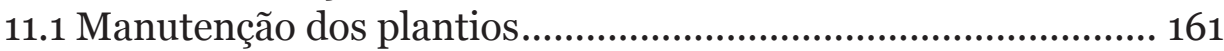

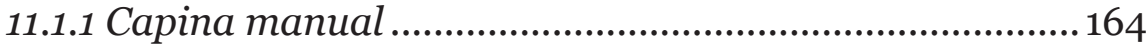

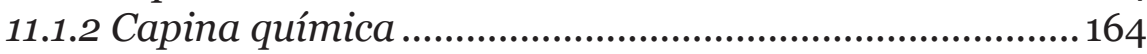

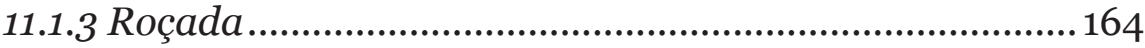

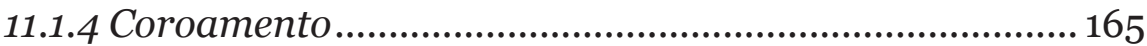

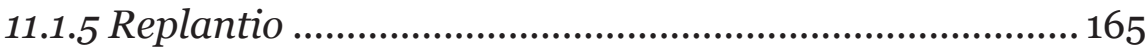

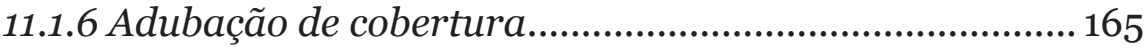

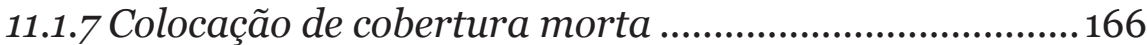

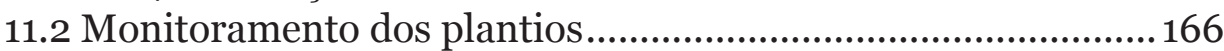

12 PRODUÇÃO DE SEMENTES E

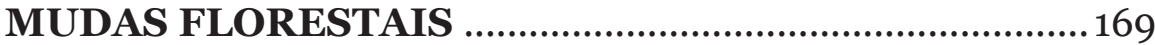

12.1 Suprimento de sementes .........................................................171

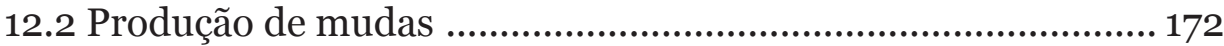

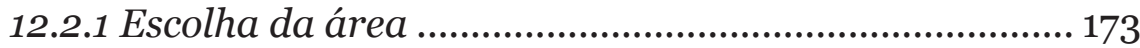

12.2.2 Zoneamento ..................................................................... 173

12.2.3 Recipientes para produção de mudas .......................... 177

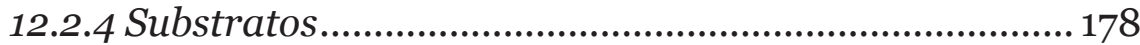

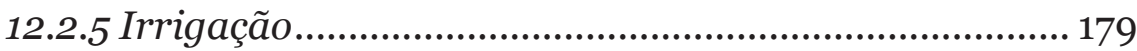

12.3 Equipe de implantação e manutenção .....................................180

12.4 Aspectos legais relacionados às mudas e sementes

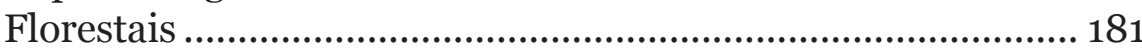

13 AÇÕES POSITIVAS PARA CONSERVAÇÃO E RESTAURAÇÃO DA MATA ATLÂNTICA NOS ESTADOS E MUNICÍPIOS ...............................................183

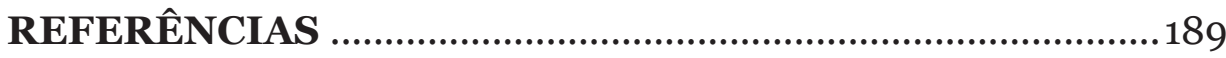


1

INTRODUÇÃO 
s florestas tropicais são ecossistemas que abrigam alta biodi-
versidade, englobando cerca de dois terços do total de espécies
existentes no planeta. O Brasil, graças as suas duas grandes florestas - Amazônica e Atlântica -, se destaca como um dos países com maior biodiversidade do planeta, possuindo cerca de 357 milhões de hectares de florestas tropicais (30\% de todas as florestas tropicais do planeta, mais que o dobro da área do segundo lugar, a Indonésia). Neste cenário, dos cerca 1,4 milhão de organismos conhecidos pela ciência, $10 \%$ vivem em território brasileiro, fazendo do Brasil, juntamente com Colômbia, México e Indonésia, os países de maior diversidade do mundo (MITTERMEIER et al., 1992). Em virtude da sua biodiversidade e dos níveis de ameaça, a Mata Atlântica, ao lado de outras 24 regiões localizadas em diferentes partes do planeta, foi indicada, por especialistas, em um estudo coordenado pela Conservação Internacional, como um dos 25 hot spots mundiais, ou seja, uma das prioridades para a conservação da biodiversidade em todo planeta (MINISTÉRIO DO MEIO AMBIENTE, 2002). Entretanto é necessário que a população brasileira se conscientize sobre o valor ambiental e socioeconômico da biodiversidade, que constitui um dos maiores patrimônios do povo brasileiro e, se bem utilizado, faria do Brasil uma potência a nível mundial. Entretanto estes biomas, principalmente a floresta atlântica, vêm sendo destruídos pela ação antrópica, onde grande parte de sua diversidade está sendo extinta antes mesmo que se conheça o potencial ecológico, genético e a importância econômica das espécies ali presentes. Necessitamos de, urgentemente, substituir o pensamento imediatista (histórico nestes últimos 500 anos) pelo planejamento em longo prazo, garantindo a perpetuidade de nossas florestas, para gerações futuras, recuperando áreas degradadas, valorizando nossa biodiversidade e aprendendo a manejá-la de forma sustentável.

Desde o início do processo de colonização portuguesa, todo processo de ocupação tem-se concentrado na faixa litorânea brasileira. A floresta atlântica está presente em 17 estados brasileiros, além de áreas na Argentina, Paraguai e Uruguai. Conforme dados do Ministério do Meio Ambiente (MMA) (2010), os remanescentes de vegetação nativa da Mata Atlântica ocupam atualmente apenas 27\% de sua área original, incluindo-se neste percentual, áreas florestais em todos os estágios de regeneração (floresta em estágio inicial, médio e avançado de regeneração e florestas primárias), campos naturais, restingas, manguezais e outros tipos de vegetação nativa, sendo que as áreas 
bem conservadas não chegam a 8\% da área original do Bioma. Assim, a Mata Atlântica vem sendo considerada uma das florestas tropicais com maior risco de extinção no planeta. Esta situação é preocupante, visto que tal recurso natural se destaca por sua alta diversidade, a floresta atlântica abriga mais de 20 mil espécies de plantas, das quais 50\% são endêmicas, ou seja, espécies que não existem em nenhum outro lugar do mundo (MMA, 2002). Na área, antes ocupada pela floresta atlântica, situam-se as grandes cidades e indústrias brasileiras, grande concentração de atividades agrícolas e pecuárias, e ainda o maior número de universidades e institutos de pesquisa do Brasil. Considerando também a importância econômica e social desta região - gera mais de 70\% do P.I.B., e seus domínios abrigam 70\% da população e concentram as maiores cidades e os grandes polos industriais do Brasil (MMA, 2002) - e a maior parte dos recursos naturais, que sustentaram a economia nacional nestes últimos 500 anos, é oriunda da floresta atlântica, podemos afirmar que muito pouco se tem feito em prol deste bioma. Hoje, na área do território original da Mata Atlântica, vivem aproximadamente 123 milhões de pessoas (67\% da população Brasileira), em 17 estados e 3.410 municípios (MMA, 2010). A Mata Atlântica é um dos 25 hot spots de biodiversidade reconhecidos no mundo, áreas que perderam pelo menos $70 \%$ de sua cobertura vegetal original, mas que, juntas, abrigam mais de $60 \%$ de todas as espécies terrestres do planeta (GALINDO-LEAL; CÂMARA, 2005).

Diante do atual quadro de destruição da floresta atlântica, consideramos quatro principais tarefas principais nas quais deveriam ser concentrados esforços, ou seja:

1. Divulgação e conscientização pública - da importância social, econômica e ambiental da floresta atlântica, incluindo todos os níveis - educação formal, professores, políticos e sociedade.

2. Conservação dos últimos remanescentes - com a finalidade de manter a diversidade ainda existente e, principalmente, os núcleos de florestas melhor conservados.

3. Prospecção da biodiversidade - visando adquirir conhecimento da variedade de espécies, sua variabilidade genética, sua autoecologia e potencial ecológico-econômico, conhecer também a variedade de ambientes (ecossistemas). 


\section{Recuperação ambiental de áreas degradadas -}

com o objetivo de resgatar parte da biodiversidade original, e manejá-la de forma sustentável, o processo de recuperação de áreas degradadas deve ser conduzido visando, principalmente, interligar grandes fragmentos florestais (florestas mais extensas e bem conservadas). Para que este processo aconteça é necessária a existência de vontade política de nossos governantes e criação de estímulos e financiamentos.

Em relação à recuperação de áreas degradadas, nas últimas décadas, têm-se multiplicado iniciativas neste sentido e, mais recentemente, surge também a preocupação em restaurar a biodiversidade original da floresta. Problemas cada vez mais frequentes, relativos a secas, erosões e perda de solo, enchentes, secamento de nascentes e rios, enfim vários impactos referentes à destruição do ecossistema original. Podemos também citar como motivos para se restaurar a vegetação, além da questão estética e paisagística, turismo, aspectos históricos, conservação de recursos hídricos, melhoria do microclima, recuperação do potencial econômico - biodiversidade, plantas medicinais, madeireiras, ornamentais, frutíferas - e atendimento a exigências legais. Mais recentemente, iniciativas de recuperação ambiental de Mata Atlântica, ligadas ao conceito de formação de corredores de biodiversidade, estão ganhando grande impulsão, pois a conexão de fragmentos florestais remanescentes é uma das melhores maneiras de se conservar e manejar a diversidade de espécies da Mata Atlântica. Também trabalhos de recuperação, visando o sequestro de carbono, começam a ganhar estímulo indicando que pode ser uma forte demanda futura de trabalhos de recuperação. A formação de uma nova consciência ambiental do povo brasileiro e, consequentemente, a mudança do perfil do consumidor incentiva o mercado a buscar selos verdes e certificados, que exigem dos negócios maior qualidade ambiental.

Se considerarmos somente a recuperação de áreas de preservação permanente (margens de cursos d'água, lagos, açudes, represas, áreas inclinadas) estados como, por exemplo, Bahia, Minas Gerais, Goiás, Mato Grosso, São Paulo, possuem mais de um milhão de hectares (cada um) degradados, necessitando de trabalhos de recuperação. Se tivermos em vista, também, a recuperação de 
áreas de reserva legal este número mais do que dobra. Ainda temos novas demandas de reflorestamentos com finalidades como fixação de carbono da atmosfera, conservação dos recursos hídricos, principalmente água para consumo humano, conservação da biodiversidade e formação de corredores ecológicos.

Neste trabalho, são discutidos métodos de recuperação de áreas degradadas, principalmente aplicados em atividades agropecuárias na região da floresta atlântica. Segundo a Fundação para Conservação e a Proteção Florestal do Estado de São Paulo (2004), a complexidade da estrutura e funcionamento dos ecossistemas tropicais e a escassez de informações sobre a ecologia das espécies são alguns dos fatores que dificultam a restauração florestal, estes autores classificam a recuperação florestal como uma atividade de silvicultura que se caracteriza por apresentar um custo inicial alto e resultados mensuráveis somente em longo prazo.

Através dos planos municipais para Conservação e Recuperação da Mata Atlântica, instituídos pela Lei n. 11.428, de dezembro de 2006 (Lei da Mata Atlântica), são abertas as possibilidades de os municípios atuarem diretamente na defesa, conservação e recuperação da vegetação nativa da Mata Atlântica. Esta lei, através do seu art. 38, institui o Plano Municipal de Conservação e Recuperação da Mata Atlântica (PMMA). Este plano torna-se muito importante para que todo município, presente no Domínio da Mata Atlântica, possua um "Banco de áreas destinadas à recuperação ambiental", fazendo um importante link entre as questões legais e a parte prática da restauração ecológica da Mata Atlântica. Observamos, hoje, que para a obtenção do licenciamento ambiental de empreendimentos urbanos e rurais, como previsto em todas as autorizações de supressão de vegetação, pode-se fazer a compensação ambiental através de plantios de recuperação ambiental de alguma área degradada. A esta demanda de áreas para serem restauradas, cabe gerar em cada município este banco com localização, disponibilidade e informações destas áreas disponíveis para recuperação ambiental, públicas ou privadas (pessoas que tenham interesse em recuperar estas áreas). Nos municípios, também, torna-se importante prever em seus planos para Conservação e Recuperação da Mata Atlântica, a conciliação/ associação de práticas de resgate e salvamento de espécies (também previstas nos processos de licenciamento ambiental) com trabalhos de restauração de áreas degradadas. Outras práticas descritas, neste 
trabalho, podem ser otimizadas, conciliando áreas de expansão urbana (onde a legislação permite supressão de vegetação nativa) com trabalhos de resgate/transposição de serrapilheira (manta orgânica florestal), sementes, plântulas para áreas em processo de recuperação, mapeadas dentro da área do município.

Neste livro, em sua $3^{\mathrm{a}}$ edição, são abordados temas com o objetivo de fornecer subsídios para quem deseja praticar a recuperação de ecossistemas degradados, levando-se em consideração aspectos técnicos, legais, culturais e econômicos do processo de recuperação, em que também apresentamos a importância das considerações da sucessão natural no processo e várias experiências práticas de recuperação ambiental em áreas de Mata Atlântica.

A nova demanda legal para adequação ambiental de propriedades rurais, promovendo a restauração das áreas de preservação permanente e de reserva legal, gera uma perspectiva de aumento das atividades de restauração em nosso país. Através do PRA - Plano de Regularização Ambiental -, todos os imóveis rurais do Brasil deverão planejar a recuperação ambiental das áreas degradadas do imóvel. A recente preocupação com a sustentabilidade e promoção do retorno da biodiversidade dos ecossistemas, que estão sendo restaurados, abre novas perspectivas e dá um novo rumo à restauração ecológica no Brasil.

Procuramos, nesta edição revisada e ampliada, abranger desde a realização de diagnósticos, metodologia para desenvolvimento de diferentes modelos de recuperação, com base nos princípios de sucessão ecológica, até roteiros para elaboração de projetos técnicos - planos de recuperação de áreas degradadas (PRAD’s), montagem de infraestrutura de apoio para projetos (serviços de coleta de sementes, implantação de viveiros de mudas), e subsídios gerais para implantar programas de recuperação ambiental apropriados para diferentes situações e escalas (diferentes áreas físicas, horizonte de tempo). 


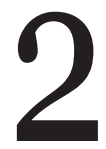

\section{HISTÓRICO E TENDÊNCIAS ATUAIS DA RECUPERAÇÃO AMBIENTAL}


$\mathrm{E}$ m todo mundo, temos a presença de áreas degradadas por diversas causas, desde o mau uso do solo na agricultura, extração de minérios, até o uso de fogo descontrolado, entre outros. Em vários países, a recuperação de áreas degradadas já era uma técnica praticada há bastante tempo, estas experiências, muitas datadas de antes de Cristo, são importantes referências, para países "jovens" como o Brasil.

Em nosso país, a primeira tentativa de recuperação de áreas ocorreu no século passado quando o Major Manuel Gomes Archer, por ordem do Imperador, iniciou, em 1886, o reflorestamento da floresta da Tijuca, neste plantio, foi utilizada uma mescla de plantas nativas e exóticas (incluindo eucaliptus). Além do plantio histórico da floresta da Tijuca, poucas iniciativas foram realizadas, destacamos o trabalho, também desenvolvido na área de floresta atlântica, de recomposição de um trecho de mata ciliar, no município de Cosmópolis, estado de São Paulo, onde o plantio foi iniciado em 1955 (NOGUEIRA, 1977). Nesta fase inicial de recuperação ambiental, no Brasil, além do pouco conhecimento da dinâmica dos ecossistemas naturais, existia uma carência muito grande de áreas de produção de mudas nativas. Estas dificuldades levaram à implantação de muitos projetos com pequena variedade de espécies, eram utilizadas as mudas que se tinha disponível, em plantios aleatórios e, muitas vezes, espécies exóticas àqueles ambientes que estavam sendo recuperados.

Com o aumento destes trabalhos, a partir da década de 1980, surgiram também novas propostas e modelos de recuperação, destacando-se os que propõem o uso da combinação das espécies de diferentes grupos ecológicos, segundo sucessão secundária, discutida por autores como Kageyama et al. (1989) e Rodrigues et al. (1990). Eles propõem o uso de modelos baseados em levantamentos florísticos e fitossociológicos de florestas remanescentes na região.

A Constituição da República Federativa do Brasil, de 1988, possui um capítulo sobre meio ambiente (art. 225), contendo inclusive a obrigatoriedade da recuperação de áreas degradadas por mineração (parágrafo $2^{\circ}$ ). Infelizmente, na Constituição, não foram consideradas áreas de estradas, áreas de preservação permanente e outras. Com as exigências legais e condicionantes de licenciamentos ambientais, diversas empresas já começam a se preocupar e a investir mais na reabilitação de áreas degradadas. 
A tendência atual, proposta neste trabalho, é que a recuperação não seja uma mera aplicação de técnicas silvicultoras, mas que se tenha um desenvolvimento de modelos de recuperação ambiental utilizando plantas nativas autóctones específicas para cada ambiente a ser recuperado, e se trabalhe com diversidade de espécies, enfocando a recuperação ambiental em um sentido mais holístico. Conforme SER (2004), a um ecossistema restaurado corresponde à recuperação da integridade, da resiliência e da sustentabilidade, proporcionando a integração com a paisagem na qual está inserido. Os novos rumos da recuperação ambiental englobam a sustentabilidade do ecossistema em processo de restauração, ou seja, esta área consegue se manter e evoluir do ponto de vista sucessional e de diversidade de espécies. Assim, não é exigido que a área retornasse a todas as características iniciais de referência (ecossistema em seu estado original naquele local, floresta primária, estágio clímax), mas consiga ser sustentável, no sentido de prosseguir o aumento contínuo da diversidade de espécies e não regrida do ponto de vista biológico. A interação maior entre restauração ecológica, envolvendo conceitos de manejo e planejamento de paisagem, é uma tendência mundial, envolvendo, então, nas etapas iniciais de planejamento da restauração, o estudo detalhado da paisagem, principalmente o entorno da área objeto da recuperação. Estes conhecimentos bióticos, juntamente com informações sobre o meio físico (solo, clima, relevo) e conceitos como o de planejamento e de ecologia de paisagem, permitem definir melhores e mais eficazes estratégias de restauração ecológica da paisagem promovendo maior integração entre a paisagem e a restauração. A Ecologia de Paisagem fornece a base para os conceitos dos corredores ecológicos e da ampliação ecológica de fragmentos florestais, estas estratégias são aplicadas eficazmente após um trabalho elaborado de planejamento de paisagem.

As novas tendências dos modelos de restauração ecológica incluem novas estratégias e modelos de recuperação, onde destacamos a recuperação ambiental com uso múltiplo, estratégia onde são considerados, no processo de recuperação, os aspectos ambientais, os aspectos sociais, econômicos, legais e culturais. Dentro desta linha, destacamos também que, no Brasil, o surgimento de iniciativas de plantios de espécies nativas para fins econômicos, existe um grande esforço no desenvolvimento de estratégias de plantios de espécies nativas, voltados para a produção econômica (produção 
madeireira e não madeireiros). A prestação de serviços ambientais (PSA) pelas florestas está cada vez mais reconhecida e estão multiplicando ações, estratégias e desenvolvimento de modelos, no sentido de promover restauração ecológica para produção de serviços ambientais (produção de água, biodiversidade, carbono etc.).

Conforme citado por Martins (2012), nas linhas metodológicas atuais, existe um enfoque comum na restauração da diversidade vegetal, das funções e processos ecológicos dos ecossistemas sem a preocupação de alcançar o clímax final. Destacamos, porém, que, mantendo a visão holística da restauração ecológica, é importante tentar se aproximar ao máximo da sequência sucessional original, trazendo para o processo de restauração o máximo de espécies nativas autóctones representantes do ecossistema e do ambiente, que está sendo restaurado, a aproximação máxima da vegetação/ecossistema original vai depender destas ações e estratégias. 


\section{3 \\ CONCEITOS \\ BÁSICOS}


$\mathrm{N}$ o Brasil, com a intensificação de trabalhos na área de recuperação ambiental, nas últimas décadas, ocorreu um desenvolvimento tecnológico nesta área. Vários grupos de trabalho, em diferentes universidades e centros de pesquisa, começaram a desenvolver pesquisas sobre o tema, e daí surgiu a necessidade de padronizar conceitos e termos técnicos, aplicados ao processo de recuperação. Dentro da ideia de padronização de termos atualmente utilizados, resolvemos incluir neste trabalho alguns conceitos mais usados.

\subsection{Alguns termos técnicos aplicados à recuperação ambiental}

1. Meio ambiente - é o conjunto de todas as condições e influências externas que afetam a vida e o desenvolvimento de um organismo. O conjunto de condições, leis, influências e interações de ordem física, química, biológica, socioeconômicas e culturais que permitem, abrigam e regem a vida em todas as suas formas (Lei n. 7.799/2001 - estado da Bahia).

2. Impacto ambiental - qualquer alteração das propriedades físicas, químicas e biológicas do meio ambiente, causada por qualquer forma de matéria ou energia resultante das atividades humanas que, direta ou indiretamente, afetem a saúde, a segurança e o bem estar da população interessada (Resolução CONAMA 001/86).

3. Habitat - área física onde o organismo vive e preenche todas suas necessidades.

4. Ecossistema - é o conjunto de componentes bióticos (vivos) e abióticos (não vivos) que, em um determinado meio, trocam matéria e energia.

5. Bioma - são superfícies imensas onde predomina determinada paisagem vegetal, caracterizada pela presença de algumas espécies dominantes e sempre associada a uma fauna específica e característica.

6. Sucessão - é o processo de desenvolvimento de uma comunidade (flora e fauna) em função de modificações no ambiente considerado, culminando no estágio clímax. As florestas se organizam lentamente através de um processo de sucessão ecológica, que se caracteriza, principalmente, 
por um gradual aumento e substituição de espécies no curso do tempo, e uma ampliação da complexidade do ecossistema (SWAINE, 1995).

7. Sucessão secundária - é um processo ecológico caracterizado por substituições que se sucedem em um ecossistema depois de uma perturbação natural ou antrópica, até chegar a um estágio estável (GOMEZ-POMPA; WIECHERS, 1979).

8. Clímax - é o estágio máximo de desenvolvimento de uma comunidade em função das condições ambientais.

9. Ecótone - é a zona de transição entre dois diferentes tipos de ecossistemas na qual encontramos elementos (indivíduos) dos dois ecossistemas.

10. Autoecologia - o estudo das necessidades de determinado organismo em condições naturais.

11. Recursos ambientais - os recursos naturais como o ar e a atmosfera, o clima, o solo e o subsolo; as águas interiores e costeiras, superficiais e subterrâneas, os estuários e o mar territorial; a paisagem, a fauna, a flora, bem como o patrimônio histórico-cultural e outros fatores condicionantes da salubridade física e psicossocial da população (Lei n. 7.799/2001 - estado da Bahia).

12. Cadeia alimentar - é a transferência de energia alimentar da fonte, representada pelas plantas, passando através de uma série de organismos (elos/níveis tróficos).

13. Área de preservação permanente - o conceito de áreas de preservação permanente foi instituído através dos artigos $2^{\circ}$ e $3^{\circ}$, do Código Florestal (Lei federal 4771/65), e compreende "as florestas e demais formas de vegetação natural situadas as margens dos cursos d'água, lagoas, lagos, reservatórios d'água naturais ou artificiais, nascentes, topo de morro, encostas, restingas, bordas de tabuleiros e chapadas, altitude superior a $1.800 \mathrm{~m}$ ", conforme descrito na legislação.

14. Degradação - em termos de áreas (local), a degradação acontece quando a vegetação e a fauna forem removidas ou expulsas; a camada fértil do solo (horizontes superficiais) for removida ou enterrada; e a qualidade e o regime de vazão do sistema hídrico forem alterados. A degradação ocorre 
quando há perdas referentes às características químicas, físicas e biológicas da área em questão (IBAMA, 1990).

15. Área degradada - é aquela que, após distúrbios, teve eliminados, juntamente com a vegetação, os seus meios de regeneração bióticos, como o banco de sementes, banco de plântulas (mudas), chuva de sementes e rebrota. Apresenta, portanto, baixa resiliência, isto é, seu retorno ao estado anterior pode não ocorrer ou ser extremamente lento, sendo a ação antrópica necessária (CARPENEZZI et al., 1990). É uma área impossibilitada de retornar por uma trajetória natural, a um ecossistema que se assemelhe a um estado conhecido antes, ou para outro estado que poderia ser esperado (IBAMA, 2011). Como exemplo, citamos as áreas de mineração, onde toda camada superficial do solo é retirada degradando vegetação e substrato. O subsolo estéril não é capaz de se regenerar sozinho.

16. Área perturbada - é aquela que sofreu distúrbios, mas manteve seus meios bióticos de regeneração. A ação humana não é obrigatória, mas somente auxilia na sua regeneração, pois a natureza pode se encarregar da tarefa (CARPANEZZI et al., 1990). Área que, após distúrbio, ainda mantém meios de regeneração biótica (KAGEYAMA et. al., 1992). Área alterada ou perturbada: área que, após o impacto, ainda mantém meios de regeneração biótica, ou seja, possui capacidade de regeneração natural (IBAMA, 2011).

17. Recuperação - significa que o sítio degradado retornará a uma forma e utilização de acordo com um plano pré-estabelecido para o uso do solo. Implica que o sítio degradado terá condições mínimas de estabelecer um novo equilíbrio dinâmico, desenvolvendo um novo solo e uma nova paisagem (IBAMA, 1990). Recuperação é a restituição de um ecossistema ou de uma população silvestre degradada a uma condição não degradada, que pode ser diferente de sua condição original (IBAMA, 2011). O termo recuperação é muito genérico, sendo utilizado em diferentes legislações, inclusive na constituição do Brasil de 1988, pode ser subdividido em: 
- Reabilitação - Conjunto de tratamentos que buscam a recuperação de uma ou mais funções do ecossistema que podem ser basicamente econômica e/ou ambiental (VIANA, 1990). É atribuir ao ambiente degradado uma função adequada ao uso humano (FUNDAÇÃO PARA CONSERVAÇÃO E A PROTEÇÃO FLORESTAL DO ESTADO DE SÃO PAULO, 2004).

- Restauração - Conjunto de tratamentos que visam recuperar a forma original do ecossistema, ou seja, a sua estrutura original, dinâmica e interações biológicas (VIANA, 1990). Conforme citado por Galvão e Medeiros (2002), o termo restauração é apenas um marco teórico, na prática consegue-se apenas a reabilitação do ecossistema. Segundo Barbosa e Mantovani (2000), a restauração é um processo intencional para restabelecer um ecossistema com o objetivo de imitar sua estrutura, função, diversidade e dinâmica originais.

- Criação - formação de um novo ecossistema, visando, exclusivamente, a recuperação de funções da floresta (IBAMA, 1990).

- Reflorestamento - é o plantio de florestas em áreas consideradas florestais, porém temporariamente não florestadas, ou o processo contrário ao desflorestamento, que consiste na supressão de florestas (FUNDAÇÃO PARA CONSERVAÇÃO E A PROTEÇÃO FLORESTAL DO ESTADO DE SÃO PAULO, 2004).

- Florestamento - é o plantio de florestas em áreas não classificadas como florestais, o que implica na transformação de paisagem de não-florestal para florestal (FAO, 2002).

\section{Forma e função:}

- Restauração da forma - trata-se do conjunto de operações em uma área degradada com objetivo de recuperar características originais do ecossistema, como a composição florística, diversidade de espécies, estrutura e dinâmica natural.

- Recuperação da função - conjunto de operações com objetivo de recuperar os serviços prestados pelo ecossistema (conservação dos solos, água, fauna etc.). 
19. Sistemas Agroflorestais (SAF) - constituem-se em uma combinação integrada de árvores, arbustos, cultivos agrícolas e/ou animais, com enfoque na produção e no sistema como um todo e não apenas no produto (VIANA, 1991). O sistema agroflorestal é uma forma de uso da terra, na qual espécies lenhosas perenes são cultivadas consorciadas a espécies herbáceas ou animais, com a obtenção dos benefícios das interações ecológicas e econômicas resultantes (IBAMA, 2011).

2o. Sistemas florestais de uso múltiplo - são áreas florestais implantadas em áreas degradadas ou perturbadas, onde a diversidade é conhecida e manejada de forma sustentada. Neste sistema, o manejo dos recursos naturais inclui a coleta de produtos florestais não madeireiros e/ ou produtos florestais madeireiros, garantindo a sustentabilidade ambiental, econômica e social. Deve-se ter o controle rigoroso das populações das plantas manejadas, visando garantir a sustentabilidade do processo.

21. Espécie exótica - espécie não originária do bioma de ocorrência de determinada área geográfica, ou seja, qualquer espécie fora de sua área natural de distribuição geográfica (IBAMA, 2011).

22. Espécies invasoras - espécies exóticas ou nativas que formam populações fora de seu sistema de ocorrência natural ou que excedam o tamanho populacional desejável, respectivamente, interferindo negativamente no desenvolvimento da recuperação ecossistêmica (IBAMA, 2011). As espécies invasoras constituem grande problema na recuperação de áreas degradadas, pois inibem o processo natural de sucessão, e aparecimento de espécies específicas de cada fase da sucessão/recuperação de áreas, principalmente competem com as espécies pioneiras.

23. Espécie ameaçada de extinção - espécie que se encontra em perigo de extinção, sendo sua sobrevivência incerta, caso os fatores que causam essa ameaça continuem atuando e constante de listas oficiais de espécies em extinção (IBAMA, 2011). Várias legislações e normas técnicas sobre recuperação preveem um percentual de plantio de espécies ameaçadas no projeto de recuperação 
ambiental. É importante verificar a listagem de espécies ameaçadas da região objeto da recuperação.

24. Espécies zoocóricas - espécies vegetais dispersas pela fauna (IBAMA, 2011). Estas espécies são de grande importância no processo de recuperação ambiental, pois a atração da fauna silvestre proporciona uma aceleração da entrada de propágulos na área em recuperação, acelerando o processo de revegetação.

25. Floresta primária - é aquela de máxima expressão local, com grande diversidade biológica, sendo os efeitos das ações antrópicas mínimos, a ponto de não afetar significativamente as características originais da floresta com relação à composição florística e à estrutura (RESOLUÇÃO CONAMA 010/1993 e RESOLUÇÃO CONAMA 388/2007). Em áreas de floresta atlântica, a floresta primária apresenta dossel superior uniforme, existindo em sua composição um grande número de espécies raras.

26. Floresta secundária em estágio avançado de regeneração - vegetação florestal onde a fisionomia arbórea é dominante sobre as demais, formando um dossel fechado e relativamente uniforme ao porte, podendo apresentar árvores dominantes, sua diversidade biológica é muito grande devido a sua complexidade estrutural (RESOLUÇÃO CONAMA 010/1993 e RESOLUÇÃO CONAMA 388/2007).

27. Floresta secundária em estágio médio de regeneração - no estádio médio de regeneração, a fisionomia arbórea e/ou arbustiva predomina sobre o estrato herbáceo, podendo constituir estratos diferenciados, serapilheira presente, variando a espessura de acordo com as estações do ano e a localidade (RESOLUÇÃO CONAMA 010/1993 e RESOLUÇÃO CONAMA 388/2007). Este estágio sucessional caracteriza-se também por apresentar epífitas, trepadeiras predominantemente lenhosas e sub-bosque presente.

28. Floresta secundária em estágio inicial de regeneração - caracteriza-se por apresentar uma fisionomia herbáceo/arbustiva de porte baixo, apresenta também trepadeiras (geralmente herbáceas), fina camada de serapilheira, presença de muitas espécies pioneiras, ausência de sub-bosque (RESOLUÇÃO CONAMA 010/1993 e RESOLUÇÃO CONAMA 388/2007). 


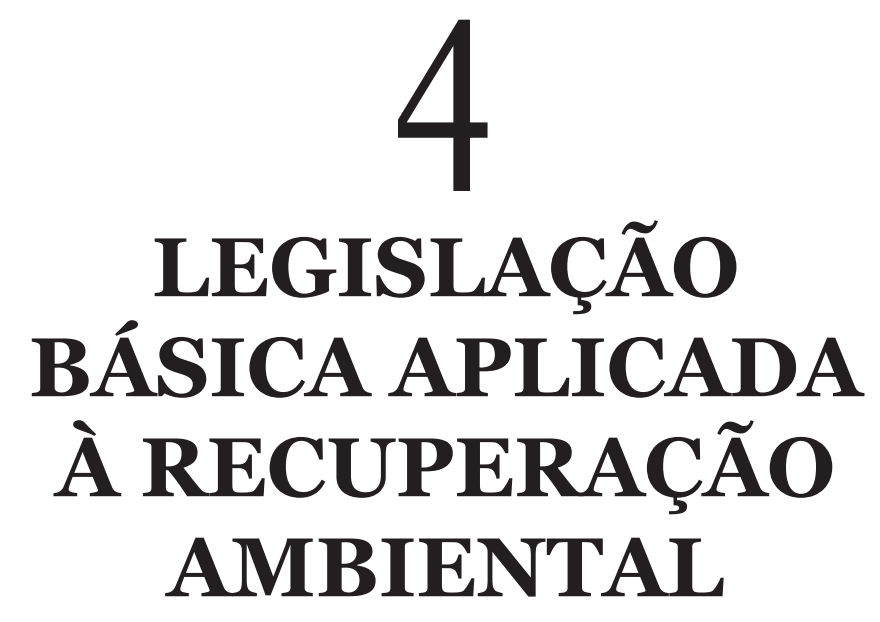




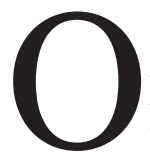

conhecimento sobre legislação ambiental aplicado à recuperação de áreas degradadas é considerado de fundamental importância para o técnico, que vai trabalhar nesta área na elaboração de projetos, pois existem dispositivos legais que normatizam o modo de apresentação dos projetos além de critérios técnicos mínimos a serem atendidos por cada projeto específico. Novos aparatos legais, como a Lei da Mata Atlântica e o novo Código Florestal de 2012, definem critérios para demarcação e recuperação das áreas de preservação permanente e reserva legal e, também, mecanismos, como a implantação do CAR - Cadastro Ambiental Rural e do PRA (Programa de Regularização Ambiental), dentro de cada propriedade, permitem, a partir deste marco legal, a demarcação de áreas, dentro do imóvel rural, onde será necessário o desenvolvimento das atividades de recuperação e de conservação ambiental. Apesar de que, no Brasil, estes dispositivos legais são recentes (primeiras leis sobre obrigatoriedade de se recuperar áreas degradadas datam do início da década de 1980). A legislação tem evoluído e hoje temos a obrigação legal de recuperação de áreas degradadas no que se refere à atividade minerária, florestas e demais formas de vegetação, situadas em áreas de preservação permanente e áreas de reserva legal (no domínio da Mata Atlântica corresponde a um percentual de $20 \%$ da área total do imóvel rural). Visando melhor orientação, discutiremos a legislação pertinente à recuperação de uma forma sucinta e prática, destacando os aspectos aplicados à parte técnica.

A legislação ambiental brasileira é considerada por especialistas em direito ambiental como sendo uma das melhores do mundo. Atualmente, todo empreendimento potencialmente impactante passa por um processo de licenciamento ambiental, em que são assumidos compromissos para adoção de medidas mitigadoras, visando o controle e a compensação ambiental desses impactos. A legislação prevê a participação popular neste processo, e possuímos recursos para responsabilizar e obrigar a todos os empreendimentos, que causem algum tipo de degradação ambiental, a apresentarem e executarem planos de reparação e compensação dos danos provocados. Entretanto falta uma maior participação popular em todo este processo, como também maior interesse dos órgãos públicos envolvidos na implementação de um sistema eficaz de controle e fiscalização, penalizando abusos contra o meio ambiente. Podemos observar, em várias 
regiões do Brasil, louváveis ações do Ministério Público estimulando ações práticas e eficazes de recuperação ambiental.

De uma forma bastante resumida, passamos a descrever as principais leis aplicadas:

1. Lei Federal 6938/81 - Lei de Política Nacional de Meio Ambiente - primeira lei no sentido de realmente organizar a política de meio ambiente e toda a estrutura governamental - no nível federal, estadual e municipal -, ligada aos assuntos ambientais. Criou o CONAMA e o SISNAMA (regulamentados pelo Decreto n. 88.351, de o1 junho de 1983), define como degradação da qualidade ambiental qualquer alteração adversa das características e elementos que integram o meio ambiente.

2. Lei Federal 7.347/85 - considerada como um grande avanço em termos de participação popular em ações relativas ao meio ambiente. Prevê ação civil pública, criando instrumentos que permitem a defesa do meio ambiente na esfera jurisdicional. Cria instrumentos para viabilizar a recuperação de áreas degradadas, através de um fundo específico e de licitação para contratação de empresa para recuperação de áreas degradadas.

3. Resolução CONAMA n. oo1/86 - estabelece critérios básicos e diretrizes gerais para o Estudo de Impacto ambiental (EIA) e Relatório de Impacto Ambiental (RIMA). Para determinados tipos de empreendimentos exige-se a realização prévia do EIA e RIMA, onde são realizados diagnósticos e planejadas ações de minimização de impactos e mitigação de prováveis danos ambientais.

4. Constituição Federal de 1988 - Artigo 225 - a floresta atlântica é considerada patrimônio nacional e sua utilização se fará, na forma da lei, dentro de condições que assegurem a preservação do meio ambiente, inclusive quanto ao uso dos recursos naturais. Consolida os instrumentos já existentes, e, a partir da Carta, temos a criação de novos institutos que são aplicáveis na proteção ambiental (ação popular, mandato de segurança 
coletivo e o mandato de injunção), além de dar maior respaldo para os mecanismos já existentes. No seu parágrafo terceiro, esta lei informa a necessidade de reparar os danos ambientais (independente das sanções penais e das multas que possam incidir sobre as pessoas físicas e jurídicas responsáveis pela degradação).

5. Decreto-lei n. $\mathbf{9 7 . 6 3 2 / 8 9}$ - regulamentou a lei $n$. 6.938/81, obrigando a recuperação da área degradada como parte do Relatório de Impacto Ambiental. Instituiu o Plano de Recuperação de Áreas Degradadas (PRAD), que pode ser empregado de forma preventiva ou corretiva, para áreas degradadas por ações de mineradoras. Convém observar que nenhum estado possui legislação específica sobre Recuperação de Áreas Degradadas, complementar à legislação federal já existente. Uma medida interessante seria a ampliação da necessidade do PRAD para outras atividades, para que isto ocorra se faz necessária a ampliação da abrangência das leis por parte do estado, não penalizando somente o setor de mineração e de construção de rodovias, mas também a aplicação em outros setores potencialmente degradadores.

6. Lei Federal n. 9.605, de fevereiro de 1998 - Dispõe sobre sanções penais e administrativas derivadas de condutas e atividades lesivas ao meio ambiente, e dá outras providências. Através do art. 23, II, obriga o infrator a recompor o ambiente degradado. É a chamada lei dos crimes ambientais, que permite abertura de uma ação e processo penal contra crimes ambientais. Esta lei prevê penalidades como prestação de serviços à comunidade, interdição temporária de direitos, suspensão parcial ou total de atividades, prestação pecuniária e recolhimento domiciliar. A partir deste dispositivo legal, também foi criado o Termo de Ajustamento de Conduta (TAC), que é formalizado pelo órgão ambiental através do Ministério Público, com o cumprimento das obrigações estipuladas no TAC, traduzidas muitas vezes em ações de recuperação de áreas degradadas, o infrator pode conseguir uma redução de até $90 \%$ do valor da multa ambiental aplicada. 
7. Decreto n. 3.420, de abril de 2000 - cria o Programa Nacional de Florestas que fomenta a "recomposição e restauração de florestas de preservação permanente, de reserva legal e áreas alteradas".

8. Resolução CONAMA 387/o6, de 27/12/2006 - dispõe sobre licenciamento obrigatório de assentamentos rurais. Nesta resolução, estão previstas ações de recuperação ambiental de áreas degradadas, através da elaboração do Plano de Recuperação do Assentamento, onde é programada a recuperação de áreas de reserva legal e de preservação permanente.

9. Lei Federal n. 11.428, de dezembro de 2006 dispõe sobre a utilização e proteção da vegetação nativa do Bioma Mata Atlântica, e dá outras providências. Esta lei estabelece as medidas compensatórias para os casos de supressão de vegetação secundária em estágio avançado e médio de regeneração, quando a recuperação será de área equivalente à área do empreendimento, com as mesmas características ecológicas, na mesma bacia hidrográfica e, sempre que possível, na mesma microbacia hidrográfica. Esta lei prevê, em seu art. 10, que "O poder público fomentará o enriquecimento ecológico da vegetação do Bioma Mata Atlântica, bem como o plantio e o reflorestamento com espécies nativas, em especial as iniciativas voluntárias de proprietários rurais".

10. Decreto n. 6.660, de novembro de 2008 - regulamenta os dispositivos da Lei Federal da Mata Atlântica (11.428/2006). Este decreto, através de seu art. 12, faculta o plantio ou o reflorestamento com espécies nativas, sem necessidade de autorização do órgão ambiental competente, incluindo aí os plantios com finalidade de recuperação ambiental e com finalidade econômica. As espécies florestais nativas plantadas devem ser cadastradas junto ao órgão ambiental competente, o cadastramento permite o corte ou a exploração destas espécies nativas comprovadamente plantadas. $\mathrm{O}$ cadastramento deve ser realizado no prazo máximo de sessenta dias, após a realização do plantio ou do reflorestamento. 
Com referência à recuperação ambiental, este decreto prevê o plano de compensação ambiental que, para obtenção da autorização de supressão de vegetação de Mata Atlântica, o requerente deve

[...] destinar área equivalente à extensão da área desmatada, para conservação, com as mesmas características ecológicas, na mesma bacia hidrográfica, sempre que possível na mesma microbacia hidrográfica e, nos casos previstos nos arts. 30 e 31 da Lei ${ }^{0} 11.428$, de 2006, em áreas localizadas no mesmo Município ou região metropolitana (art. 26 do Decreto $\mathrm{n}$. $6.660 / 2008)$.

Conforme $\S 2^{\circ}$ deste mesmo art. 26 a

[...] execução da reposição florestal deverá seguir as diretrizes definidas em projeto técnico, elaborado por profissional habilitado e previamente aprovado pelo órgão ambiental competente, contemplando metodologia que garanta o restabelecimento de índices de diversidade florística compatíveis com os estágios de regeneração da área desmatada.

11. Instrução normativa n. 4, de 13 de abril de 2011 - esta instrução estabelece procedimentos para elaboração de Projeto de Recuperação de Área Degradada - PRAD ou Área Alterada. Esta instrução traz como anexos Termos de Referência e distingue dois tipos de PRAD (PRAD e PRAD simplificado), aplicados conforme cada caso especificado na norma. Na instrução, é determinado que "o PRAD deve reunir informações, diagnósticos, levantamentos e estudos que permitam a avaliação da degradação ou alteração e a consequente definição de medidas adequadas à recuperação da área”. Este dispositivo proposto pelo IBAMA orienta então como elaborar um PRAD para apresentação aos órgãos federais.

12. Lei Federal n. 12.651/12 - Novo Código Florestal - o novo Código Florestal prevê a recomposição gradual das áreas de reserva legal e recuperação das áreas de preservação permanente em diferentes faixas, confome o tamanho dos imóveis rurais. As áreas de 
preservação permanente e de reserva legal, que não possuem mais sua vegetação natural, são consideradas degradadas, portanto necessitam legalmente de serem recuperadas. Em seu artigo primeiro, o novo Código Florestal estabelece, em suas alíneas 6, 7 e 8, a responsabilidade comum de União, Estados, Distrito Federal e Municípios, em colaboração com a sociedade civil, na criação de políticas para a preservação e restauração da vegetação nativa e de suas funções ecológicas e sociais nas áreas urbanas e rurais, assim como a inovação para o uso sustentável e a recuperação, além de criação e mobilização de incentivos jurídicos e econômicos para fomentar a preservação e a recuperação da vegetação nativa.

A recuperação das áreas de Reserva Legal está prevista no artigo 17, do Código Florestal, onde temos: "deverá ser iniciado o processo de recomposição da Reserva Legal em até dois anos contados a partir da data da publicação desta Lei, devendo tal processo ser concluído nos prazos estabelecidos pelo Programa de Regularização Ambiental - PRA”. Também o art. 66, em seu parágrafo segundo, determina que a recomposição da área de reserva legal deverá ser concluída em até 20 (vinte) anos, abrangendo, a cada 02 (dois) anos, no mínimo 1/10 (um décimo) da área total necessária para sua complementação.

No capítulo X do novo Código Florestal, temos o programa de apoio e incentivo à preservação e recuperação do meio ambiente, no qual são mencionadas linhas de financiamento específicas assim como isenção de impostos e utilização de fundos públicos, também apoio técnico e financeiro (art. 58) e Programas de Regularização Ambiental - PRA (art. 59), onde estão previstas todas as estratégias de recuperação de áreas degradadas na propriedade rural.

Assim, vários dispositivos legais, principalmente o novo Código Florestal, incentivam a restauração de áreas degradadas, a necessidade de adequação ambiental dos imóveis rurais, conservando as áreas florestais existentes como reserva legal e áreas de preservação permanente e promovendo a recuperação de áreas degradadas é um mecanismo muito importante para conservação dos biomas brasileiros. 
Existem outros dispositivos legais relacionados à restauração florestal especificamente para os estados brasileiros, estes dispõem desde as compensações ambientais (alguns estados atrelam a liberação de desmatamento a plantios de restauração compensatórios com a mesma área ou maiores) até o estabelecimento e regras de plantios de restauração (número de espécies a serem utilizadas, percentagens de uso de espécies ameaçadas de extinção, número de espécies frutíferas etc.).

Para a Mata Atlântica, a recomposição/conservação das áreas de reserva legal e a preservação permanente podem significar a recuperação deste bioma. Considerando que, atualmente, mais de 70\% dos remanescentes de Mata Atlântica estão nas mãos de particulares, a criação de mecanismos que incentivem a recuperação de áreas degradadas (reservas legais ou preservação permanente) e conservação dos últimos remanescentes pode representar uma recuperação real de nossa floresta atlântica. 


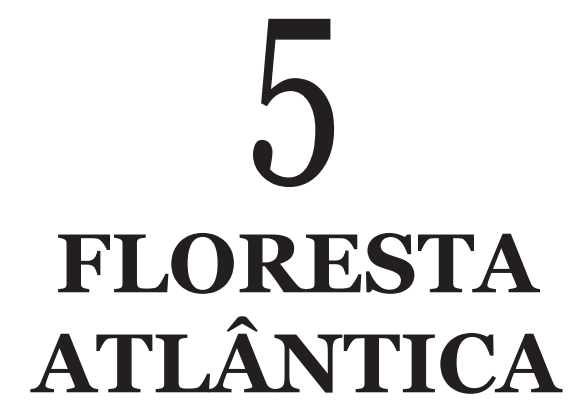




\subsection{Conceituação e distribuição}

$\mathrm{S}$

egundo o Consórcio Mata Atlântica/UNICAMP (1992), baseado no Manual Técnico da Vegetação Brasileira (IBGE, 1992), a floresta atlântica compreende um conjunto de tipologias vegetais, localizada na faixa litorânea brasileira, desde o Estado do Rio Grande do Norte até o Estado do Rio Grande do Sul, representado, principalmente, pela Floresta Ombrófila Densa, Floresta Estacional Semidecidual, Floresta Estacional Decidual, encraves de campos de altitude e brejos de altitude (Região Nordeste), associada também a ecossistemas costeiros de restinga, mussunungas e mangue. A atual legislação brasileira também segue e considera este conceito para floresta atlântica. Alguns autores, como Leitão Filho (1993), Joly et al. (1991) e Silva e Leitão Filho (1982), consideram a floresta atlântica de forma mais restrita, restringindo este bioma somente à floresta ombrófila densa.

Fatores como a grande variação latitudinal (de $5^{\circ}$ a $25^{\circ}$ de latidude sul), variação de altitudes (desde o nível do mar até mais de 1.000 metros acima), contatos temporários com a Floresta Amazônica, durante os períodos interglaciais, além da presença de muitos ecossistemas associados - campos de altitude, restinga, mangues, brejos etc. - fazem da floresta atlântica um dos ecossistemas de maior diversidade biológica do planeta.

\subsection{Processo de fragmentação}

Nestes cinco séculos pós-descobrimento, o país passou por diferentes ciclos econômicos (pau-brasil, cana-de-açúcar, mineração, café e pecuária), todos concentrados na faixa litorânea e responsáveis pelo desmatamento e fragmentação da floresta atlântica, logo se observa que o processo de fragmentação está sempre associado aos ciclos econômicos brasileiros e à expansão urbana. Na FOTO 1, podemos observar grandes extensões de áreas de pastagens degradadas, presentes no norte fluminense (estado do Rio de Janeiro), pastagens formadas após o ciclo do café, um dos primeiros ciclos econômicos a devastar grandes extensões de floresta atlântica, esta monocultura, comum na costa brasileira, empregou grandes áreas, antes ocupadas pela floresta. 
FOTO 1 - Extensas áreas antes ocupadas por mata atlântica, hoje ocupadas por pastagem degradadas presentes na zona da mata do estado de Minas Gerais.

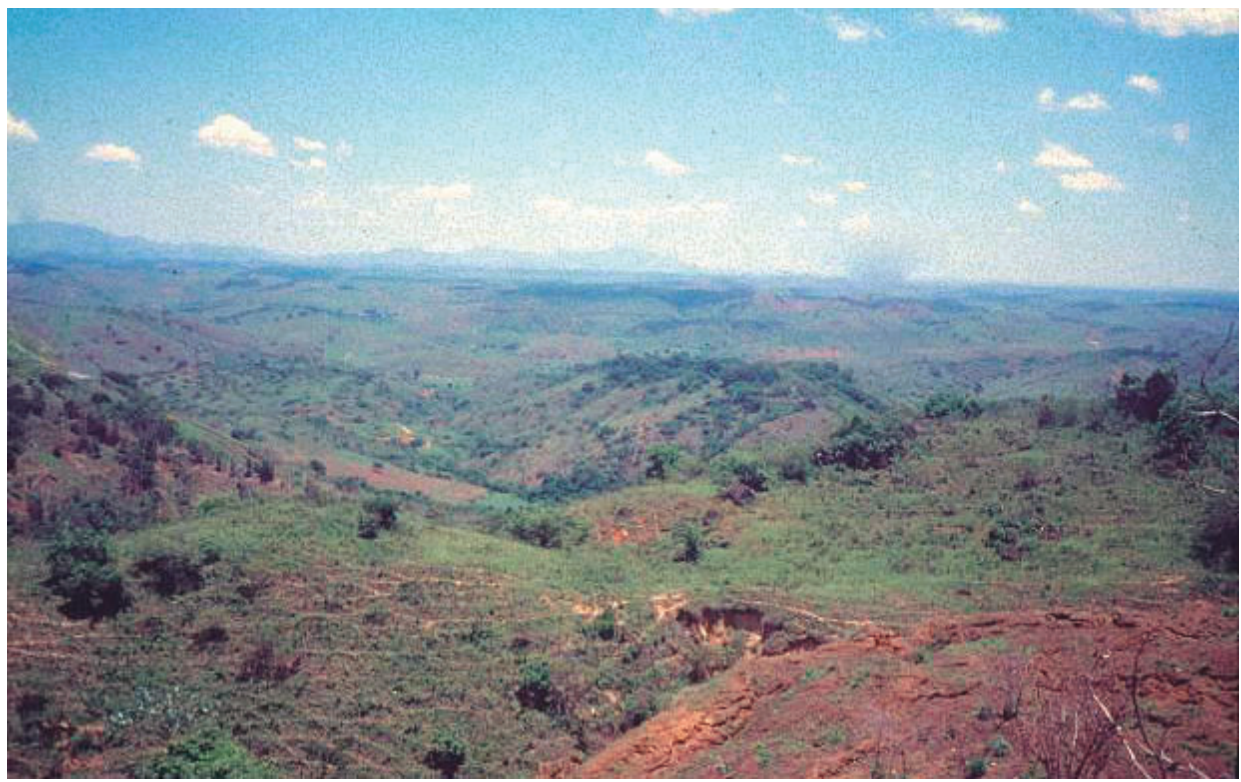

Segundo Mori et al (1991), o desmatamento da Mata Atlântica é particularmente sério, uma vez que este ecossistema apresenta uma alta diversidade e elevado nível de endemismo, levando à extinção de um número incalculável de espécies e populações.

O maior impacto do processo de fragmentação florestal é a drástica redução dos habitats, da diversidade biológica, interrompendo relações ecológicas, extinguindo espécies da flora e da fauna. A eliminação de grandes trechos da floresta, conforme citado por Rankin-de-Merona e Ackerly (1987), causa mudanças no microclima e outras características do habitat, perda de indivíduos reprodutivos da população, modificação ou eliminação de relações ecológicas com espécies polinizadoras e dispersoras, que afetam a capacidade das espécies sobreviverem na "ilha".

Pequenos fragmentos florestais se encontram, em sua maioria, comprometidos em relação a sua biodiversidade e sustentabilidade. É característica marcante destes fragmentos de área reduzida apresentar problemas quanto ao tamanho das populações, muitas espécies são raras - apresentam pequenas densidades - menos que um indivíduo por hectare, muitas árvores mortas e grande infestação de cipós, chegando a alguns casos - fragmentos isolados - em mais de 70\% das árvores com presença de cipó na copa ou no tronco 
(ALMEIDA, 1996). Com a retirada - extrativismo e erradicação - de espécies de interesse comercial das populações humanas -, a composição original da floresta é alterada, com domínio de certos grupos de espécies.

O mais importante, segundo enfatizado por Frankel e Soulé (1981), encontra-se no alto nível de especialização e autodependência de espécies das florestas tropicais, como a floresta atlântica, pode-se determinar que a perda de uma espécie de planta é capaz de desencadear uma extinção em cascata, efeito dominó, levando à perda de inúmeras outras espécies.

O estudo da fragmentação florestal está sendo realizado, em grande parte, baseado na Teoria de Biogeografia de Ilhas Oceânicas, proposta por Robert MacArthur e Edward Wilson, em 1963, onde uma diminuição da superfície está normalmente associada a uma diminuição exponencial do número de espécies e da redução das relações interespecíficas (MAC ARTHUR; WILSON, 1967; FRANKEL; SOULÉ, 1981). Estes conceitos propostos auxiliam na interpretação e estudos das modificações provocadas pelo processo de isolamento de pequenas áreas florestais. Esta teoria tem sido aplicada com muita ênfase na criação de unidades de conservação, marcação de reservas naturais e elaboração de planos de manejo de fragmentos florestais, tanto para conservação da biodiversidade como para produção madeireira. Em recuperação de áreas degradadas, esta teoria auxilia em trabalhos de interligações de fragmentos, recuperações de bordas de fragmentos, recuperação genética de populações, entre outros.

\subsection{Biodiversidade}

A biodiversidade compreende a totalidade de genes, espécies e ecossistemas existentes em uma região (CIMA, 1991; DIAS, 1992). Segundo Burton et al. (1992), a diversidade biológica, ou biodiversidade, pode significar uma variedade de formas de vida (especialmente espécies) de forma generalista, dependendo do contato e da escala, pode referir-se a alelos ou genótipos dentro de uma população, ou a espécies e formas de vida contidas em uma comunidade biótica, assim como espécies e ecossistemas dentro de uma paisagem.

Nas florestas tropicais, a diversidade está organizada de maneira bastante fragmentada no espaço e no tempo, em razão da alta 
heterogeneidade de ambientes físicos (microclima, solos, topografia), bióticos, fisiológicos (variação química do metabolismo secundário) e, especialmente, sucessionais (pela frequência de perturbações brandas e imprevisíveis) nesses sistemas (REIS et al., 1992).

Com referência à biodiversidade, na área de domínio da floresta atlântica, podemos notar que, baseado nos atuais níveis de degradação desse ecossistema, sua biodiversidade já está comprometida, onde certamente muitas espécies já foram extintas antes mesmo de serem descritas pela ciência. Entretanto, a floresta atlântica, mesmo reduzida à área atual, colabora em muito para que o Brasil seja considerado um país de megabiodiversidade.

No domínio da floresta atlântica, temos 53,5\% de endemismo entre as espécies arbóreas, também 74,4\% das espécies de bromélias e $64 \%$ das 76 espécies de palmeiras. Com relação à fauna, a floresta atlântica apresenta um endemismo bastante elevado: 91,8\% das 183 espécies de anfíbios; $39 \%$ de cerca das 23 espécies de marsupiais; 41\% das 146 espécies de répteis; 53\% das 57 espécies de roedores existentes; além de 39\% de cerca das 130 espécies de mamíferos são endêmicas (CONSÓRCIO MATA ATLÂNTICA; UNICAMP, 1992).

Em estudo feito pela Conservação Internacional, a Mata Atlântica foi considerada um dos 25 hotspots do mundo, em função de sua alta diversidade de espécies (cerca de 300-500 espécies vegetais/ ha em florestas primárias), associada a uma alta taxa de endemismo (50 \% das espécies vegetais) e do grau de ameaça que este ecossistema vem sofrendo (reduzido a cerca de $7 \%$ de sua área original).

Com relação ao número total de animais e microrganismos das florestas tropicais, estes são cerca de 100 vezes o total de espécies vegetais (KRICHER, 1990). Este grande número de animais e microrganismos nessas florestas tropicais é responsável pelos processos de polinização, dispersão de sementes e predação (KAGEYAMA; GANDARA, 1999).

Considerando a grande biodiversidade e o potencial biológico, econômico e social da floresta atlântica, registramos a necessidade de manter e manejar estes últimos fragmentos florestais, conservando a grande biodiversidade ainda existente. A diversidade de espécies da floresta atlântica, ainda pouco conhecida e muito danificada, proporcionará muitas surpresas após trabalhos de pesquisa e seu completo conhecimento. 


\section{6}

ALGUNS PRINCÍPIOS DE SUCESSÃO NATURAL

APLICADOS AO PROCESSO DE RECUPERAÇÃO 
$\mathrm{A}$ restauração de ecossistemas degradados envolve conhecimentos diversos, principalmente, no que se refere à recons- conhecimento da dinâmica natural e da estrutura do ecossistema é fundamental no desenvolvimento de modelos de recuperação, mesmo sabendo que não será atingido o retorno à condição original do ecossistema a ser restaurado.

Entende-se como sucessão natural o processo de desenvolvimento de uma comunidade (ecossistema), em função de modificações das composições no ambiente considerado, culminando no estágio clímax. O processo de colonização inicia-se com espécies pioneiras, adaptadas às condições (limitações) apresentadas, que criam condições adequadas de microclima e solo para estabelecimento de outros grupos de plantas - secundárias - espécies que necessitam de menos luz e melhores condições de solo. Esta sequência sucessional evolui até um estágio final (clímax), representado por um grande número de espécies, representado por poucos indivíduos, portanto com maior diversidade. Cada fase de sucessão é caracterizada por composições florísticas e faunísticas típicas, associadas entre si. No processo de recuperação ambiental, é imprescindível o conhecimento da autoecologia das espécies animais e vegetais, envolvidas em cada estágio sucessional, visando "copiar" a natureza e acelerar o processo, mesmo sabendo que não conseguiremos atingir o mesmo estágio da vegetação clímax original, isto é, não chegaremos mais a retornar a vegetação ao seu estado original, porém a reprodução deste caminho da sucessão ecológica deve ser seguida ao máximo. Sabemos que, na prática, a sucessão pode seguir múltiplas trajetórias, se considerarmos que os sistemas naturais são abertos e sujeitos a interferências antrópicas e naturais.

\subsection{Grupos ecofisiológicos}

A classificação das espécies em grupos ecofisiológicos permite agrupar as espécies com características sucessionais similares, dando uma ideia do comportamento das diversas espécies no ecossistema. Este conceito tem grande aplicabilidade na restauração ecológica.

Com referência aos grupos ecofisiológicos de espécies, uma das primeiras classificações utilizadas para a reunião de espécies 
em grupos ecofisiológicos foi realizada por Budowski (1965). De acordo com este autor, as espécies foram classificadas, segundo o estádio sucessional em: pioneiras, secundárias iniciais, secundárias tardias e clímax. Autores como Bazzaz e Pickett (1980), Swaine e Whithmore (1988) e Almeida (1996) trabalharam com a classificação de espécies em grupos ecofisiológicos de espécies. A utilização da classificação das espécies em grupos ecofisiológicos torna-se, a cada dia, mais embasada cientificamente, deixando de lado o caráter subjetivo das classificações iniciais.

Aqui incluímos uma classificação adicional da forma da copa, característica também muito importante no processo de restauração ecológica que ganhou muita importância nos trabalhos de recuperação ambiental nos últimos anos, em especial observando critérios de melhor recobrimento e proteção dos solos e redução de custos de manutenção. As espécies que possuem copa mais larga fornecem uma maior e mais rápida proteção dos solos da área que está sendo restaurada, pela geração de sombra mais rápida em relação a outras espécies, reduzindo o período necessário para manutenção das áreas em processo de recuperação e, consequentemente, diminuindo o custo financeiro da restauração ecológica. Neste trabalho, incluímos, juntamente com a tradicional classificação de grupos ecofisiológica de espécie, a classificação da forma da copa, pois estas duas classificações somadas dão uma boa ideia do desempenho da espécie no campo. Algumas espécies têm destaque no crescimento precoce da copa (aroeirinha - Schinus terebentifolius - por exemplo), apresentando uma cobertura densa de copa em curto espaço após o plantio, o que elimina a vegetação competidora rasteira (principalmente gramíneas) que existia na área antes do plantio. Esta classificação somente é aplicada para espécies pioneiras e secundárias iniciais, os outros grupos ecofisiológicos de espécies (secundárias tardias e clímax), devido a seu comportamento fisiológico e crescimento, sempre em ambientes sombrios, tendem sempre, no momento inicial, a crescer verticalmente, buscando ocupar o dossel superior e, posteriormente, somente quando atingem o dossel superior, que buscam o crescimento horizontal de suas copas.

Baseado em observações de campo e nos diferentes trabalhos já realizados sobre ecofisiologia vegetal (COSTA et al., 1992; GONÇALVES et al., 1992; ALMEIDA, 1996), podemos agrupar as espécies pertencentes aos diferentes grupos ecofisiológicos em: 


\section{Espécies Pioneiras}

- Desenvolvem-se em grandes clareiras, bordas de fragmentos florestais, locais abertos e áreas degradadas.

- Pequeno número de espécies por ecossistema, porém em alta densidade, principalmente, em fragmentos florestais em estágio inicial e médio de regeneração.

- Capacidade de adaptação em ambientes variados, existe sempre uma espécie pioneira típica de cada ambiente.

- Alta tolerância à luz e intolerantes à sombra.

- Pequeno ciclo de vida (10-20 anos).

- Árvores de pequeno porte (geralmente menores que 10 metros de altura).

- Apresenta floração e frutificação precoce (algumas espécies chegam a florescer ainda na fase de viveiro, 6 meses após semeio).

- Sementes em geral pequenas, produzidas em grandes quantidades.

- Dispersão de sementes por agentes generalistas.

- Conservação do poder germinativo das sementes por longos períodos - permanece no banco de sementes do solo.

- Frutos e folhas altamente atrativas para animais silvestres.

- Altas taxas de crescimento vegetativo.

- Sistemas radiculares de absorção mais desenvolvidos.

- Alta plasticidade fenotípica.

- Grande amplitude ecológica (dispersão geográfica).

- Raramente formam associações micorrízicas.

- Madeira clara e de baixa densidade.

Exemplos de algumas espécies pioneiras típicas para área de floresta atlântica: Cecropia spp. (Embaúbas), Vismia spp. (Maria Preta, Copiã), Miconia spp. (Jacatirão, Quaresminha, Pequi de Capoeira), Croton floribundus (Sangue-d'água, Velame), Trema micrantha (Crindiúva, Pau -pólvora, Gurindiba), Aegiphila sellowiana (Fruta-de -papagaio, Fidalgo), Schinus terebentifolius (Aroeirinha, Aroeira pimenteira), Dictyoloma vandelianum (Brauninha, Tingui-preto, Mauí) e Rapanea spp. (Capororoca, Pororoca). 
FOTO 2 - Espécie pioneira (Cecropia hololeuca Miq.), no telhado da estação ferroviária, no município de Além Paraíba, Estado do Rio de Janeiro

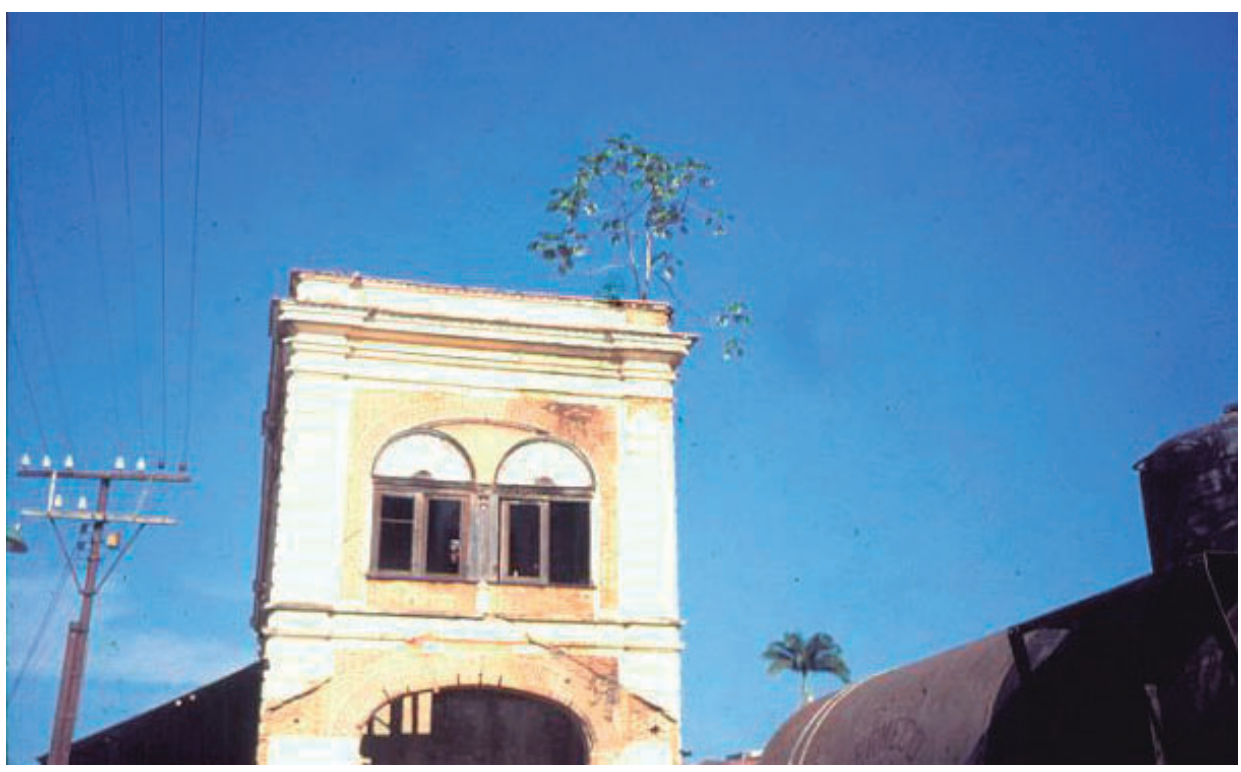

Baseado em observações de campo (ALMEIDA, 2007), podemos agrupar as espécies pioneiras em dois subgrupos diferentes, quanto à forma de copa e crescimento horizontal da copa, em:

Espécie pioneira de copa curta - espécie arbórea de crescimento mais em altura (vertical) e de copa de diâmetro não muito expressivo (menor que 2 metros, quando árvore adulta). Estas espécies por não possuírem boa projeção horizontal da copa, não sombreiam bem os estratos inferiores, solo e sub-bosque, isto é, não conferem boa proteção aos solos em relação às espécies pioneiras de copa larga.

Exemplos de algumas espécies pioneiras de copa curta para área de floresta atlântica: Cecropia spp. (Embaúbas), Miconia spp. (Jacatirão, Quaresminha, Pequi de Capoeira), Schizolobium parahybum (Guapuruvu), Aegiphila sellowiana (Fruta-de-papagaio, Fidalgo) e Rapanea spp. (Capororoca, Pororoca).

Espécie pioneira de copa larga - espécie arbórea de comportamento pioneiro, rápido crescimento, bem balanceado entre crescimento em altura (vertical) e horizontal (projeção da copa). Es- 
FOTO 3 - Espécie pioneira de copa curta (Aegiphila sellowiana Cham.), oferece pouca proteção ao solo, município de Juiz de Fora, Estado de Minas Gerais

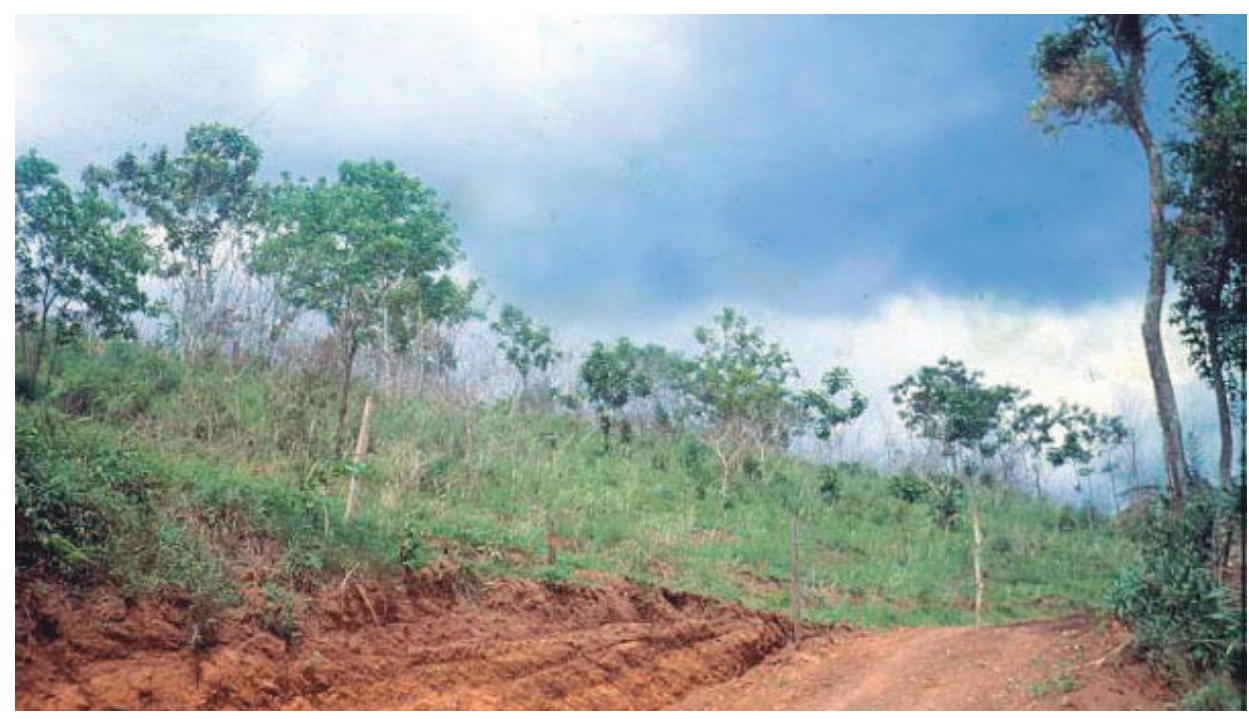

tas espécies possuem um bom desenvolvimento horizontal da copa, proporcionando precocemente um bom sombreamento e recobrimento do solo. Elas têm maior capacidade de competir com espécies de gramíneos presentes, muitas vezes eliminando, em função do sombreamento, a vegetação gramínea competidora, protegendo os solos das ações erosivas. São espécies ideais para uso, quando queremos reduzir os custos de manutenção e, até mesmo, abolir o uso de herbicidas, muitas vezes de uso restrito em algumas solicitações.

Exemplos de algumas espécies pioneiras de copa larga ocorrentes no domínio da floresta atlântica: Vismia spp. (Maria Preta, Copiã), Croton floribundus (Sangue-d'água, Velame), Trema micrantha (Crindiúva, Pau-pólvora, Gurindiba), Schinus terebentifolius (Aroeirinha, Aroeira-pimenteira) e Inga marginata (Ingámirim, Brauninha).

\section{Secundárias Iniciais}

- São plantas que se desenvolvem em locais totalmente abertos e semiabertos e clareiras na floresta. São plantas lucíferas e aceitam somente o sombreamento parcial.

- Árvores de tamanho variado entre 12-20 metros. 
- Sementes de tamanho pequeno e médio, geralmente apresentam algum tipo de dormência e de relativa viabilidade longa.

- Produzem boas quantidades de sementes, quando em boas condições de iluminação da copa.

- Sementes geralmente dispersas por pássaros, morcegos, gravidade e vento.

- Convivem com as pioneiras, nas fases iniciais da sucessão florestal, mas em menor densidade - menor número de indivíduos por unidade de área.

- Rápido crescimento vegetativo.

- Ciclo de vida médio (15-30 anos).

Exemplos de algumas espécies secundárias iniciais típicas para área de floresta atlântica: Bauhinia forficata (Pata-de-vaca), Senna multijuga (Cobi, Aleluia), Zanthoxylum rhoifolia (Mamica-de-porca), Casearia sylvestris (Café-do-mato, Língua-de-teiú, Aderninho), Cupania spp. (Camboatá), Scheflera morototoni (Mandiocão, Matataúba), Alchornea iricurana (Licurana), Inga spp. (Ingá) e Senna macranthera (Fedegoso).

Baseado em observações de campo (ALMEIDA, 2007), podemos subgrupar as espécies secundárias em dois subgrupos de forma de copa e crescimento horizontal da copa, como:

Espécie secundária inicial de copa curta - espécie arbórea secundária inicial que não desenvolve bem a copa no sentido da projeção horizontal, não formando uma boa proteção e sombreamento dos estratos inferiores, solo e sub-bosque.

Exemplos de algumas espécies secundárias iniciais de copa curta para área de floresta atlântica: Bauhinia forficata (Pata-devaca), Senna multijuga (Cobi, Aleluia), Cupania spp. (Camboatá) e Scheflera morototoni (Mandiocão, Matataúba).

Espécie secundária inicial de copa larga - espécie arbórea secundária inicial que possui um bom desenvolvimento vertical da copa, proporcionando precocemente um bom sombreamento e recobrimento do solo, eliminando, em função do 
sombreamento, a vegetação gramínea competidora e, consequentemente, reduzindo custos de manutenção.

Exemplos de algumas espécies secundárias iniciais típicas para área de floresta atlântica: Zanthoxylum rhoifolia (Mamicade-porca), Peltophorum dubium (Canafistula), Casearia sylvestris (Café do mato, Língua-de-teiú, Aderninho), Alchornea iricurana (Licurana) e Senna macranthera (Fedegoso).

\section{Secundárias Tardias}

- Desenvolvem-se exclusivamente em sub-bosque, em áreas permanentemente sombreadas, crescem e completam seu ciclo à sombra. Em sua fase adulta, ocupam quase sempre os estratos superiores da floresta.

- Suas mudas vão compor o banco de plântulas da floresta.

- Iniciam sua presença em estágios médios de sucessão.

- As árvores deste grupo são geralmente de grande porte.

- Ciclo de vida longo.

- Suas sementes são dispersas por vento, gravidade e também por alguns animais;

- Sementes médias e grandes.

Exemplos de algumas espécies secundárias tardias, para área de floresta atlântica: Centrolobium tomentosum (Araribá, Putumuju), Dalbergia nigra (Jacarandá), Bowdichia virgilioides (Sucupira), Vochysia spp (Pau-de-tucano, Uruçuca), Apuleia leiocarpa (Garapa, Jataí) e Esenbeckia leiocarpa (Durão, Guarantã).

As espécies secundárias tardias devido a seu comportamento fisiológico e crescimento sempre em ambientes sombrios tendem sempre, no momento inicial, a crescer verticalmente, buscando ocupar o dossel superior e, posteriormente, somente quando atingem o dossel superior, procuram o crescimento horizontal de suas copas. Portanto não são classificadas quanto à forma da copa que varia conforme o posicionamento no dossel da floresta.

\section{Espécies Clímax}

- Regeneram-se e se desenvolvem em plena sombra, sendo típicas de ambiente de floresta primária. 
- Na fase adulta, em florestas primárias ou em estágios avançados, ocupam os dosséis superiores da floresta, e muitas árvores deste grupo são emergentes (suas copas se situam sobre o dossel superior da floresta).

- Suas sementes possuem, geralmente, pequena viabilidade e, raramente, apresentam algum tipo de dormência, germinando logo que caem sobre o solo.

- Suas sementes sofrem grande predação.

- Sementes grandes dispersas por gravidade e, mais comumente, por mamíferos e roedores.

- Espécies vegetais com estreita relação com animais polinizadores e dispersores.

- Apresentam baixa densidade por área (geralmente são espécies raras).

- Árvores adultas muito altas, na floresta atlântica, chegam a mais de 40 metros de altura.

- São espécies típicas de florestas primárias e nos estágios avançados de sucessão.

- Em fragmentos florestais isolados são quase sempre espécies raras.

- Ciclo de vida longo muito longo, acima de 100 anos, quando em condições estáveis - florestas primárias.

- Definem a estrutura final da floresta.

- Crescimento vegetativo lento, alta densidade da madeira.

- Estão presentes, neste grupo, grande parte das espécies arbóreas produtoras de madeiras nobres, de alto valor econômico.

- Presença de sistema radicular atrofiado, com poucas raízes de absorção.

- A maior parte das espécies é formadora de associações micorrízicas.

Alguns exemplos para área de floresta atlântica: Virola bicuhyba (Bicuíba/Virola), Lecythis pisonis (Sapucaia), Cariniana spp. (Jequitibás), Manilkara spp (Paraju, Massaranduba), Slonea guianensis (Gindiba), Cedrella fissilis (Cedro), Cedrella odorata (Cedro-da-bahia), Caesalpinia echinata (Pau-brasil) e Geonoma pohliana (Ouricana). 
Como no caso das espécies secundárias tardias, as espécies clímax também apresentam comportamento fisiológico de crescimento sempre em ambientes sombrios (sub-bosque da floresta), onde aguardam abertura de espaço para atingirem o dossel superior, apresentando, portanto formas e crescimento de copa variado, conforme a posição no dossel da floresta. As espécies deste grupo, inicialmente, vão compor o banco de plântulas da floresta. Elas germinam e ficam como mudas, compondo o sub-bosque até surgir espaço e luz para o desenvolvimento. No sub-bosque, existem plântulas com idade superior a 10-20 anos de pequeno porte, que estão aguardando esta abertura do dossel para seu desenvolvimento como indivíduo arbóreo.

Quanto ao número de espécies dos grupos ecofisiológicos presentes, em áreas de floresta atlântica, este vai variar conforme o estágio sucessional. Em estágios iniciais de sucessão, é maior a participação de espécies pioneiras e secundárias iniciais, em florestas em estágios sucessionais mais avançados e florestas primárias, observamos uma maior participação de espécies secundárias tardias e clímax. Em áreas de florestas primárias, é raro encontrarmos espécies pioneiras. Observamos, no TABELA 1, o resultado de alguns estudos realizados em áreas de floresta atlântica.

TABELA 1 - Distribuição percentual de espécies nos diferentes grupos Ecofisiológicos de espécies presentes em diferentes estudos conduzidos em fragmentos florestais de Mata Atlântica em estágio médio de regeneração

\begin{tabular}{|c|c|c|c|c|}
\hline $\begin{array}{l}\text { Grupo } \\
\text { Ecofisiológico }\end{array}$ & \multirow{2}{*}{$\begin{array}{l}\text { PIONEIRAS } \\
(\%)\end{array}$} & \multirow{2}{*}{$\begin{array}{c}\text { SECUNDÁRIA } \\
\text { INICIAL } \\
(\%)\end{array}$} & \multirow{2}{*}{$\begin{array}{c}\text { SECUNDÁRIA } \\
\text { TARDIA/ } \\
\text { CLÍMAX/ } \\
(\%)\end{array}$} & \multirow{2}{*}{$\begin{array}{c}\text { SEM } \\
\text { CLASSIFICAÇÃO } \\
(\%)\end{array}$} \\
\hline $\begin{array}{l}\text { AUTOR/ ANO } \\
\text { LOCALIDADE }\end{array}$ & & & & \\
\hline $\begin{array}{l}\text { COSTA et al (1992) } \\
\text { Linhares/ ES }\end{array}$ & 23,00 & 57,00 & 20,00 & - \\
\hline $\begin{array}{l}\text { GANDOLFI (1991) } \\
\text { Guarulhos/SP }\end{array}$ & 25,00 & 30,00 & 34,00 & 11,00 \\
\hline $\begin{array}{l}\text { SALIS (1991) } \\
\text { Brotas/SP }\end{array}$ & 16,40 & 51,64 & 0,82 & 31,14 \\
\hline $\begin{array}{l}\text { ALMEIDA (1996) } \\
\text { Juiz de Fora/ MG }\end{array}$ & 19,23 & 52,57 & 28,20 & - \\
\hline
\end{tabular}




\subsection{Composição florística e fitossociológica}

As informações sobre composição florística e fitossociológica são obtidas através de levantamentos da estrutura da vegetação de remanescentes florestais. Na etapa de diagnósticos, os estudos florísticos e fitossociológicos são de suma importância para o sucesso ou atendimento do objetivo de restauração ambiental de um projeto. As informações sobre as espécies, que serão utilizadas, e a densidade de plantio são obtidas através destes estudos. Normalmente, a partir dos estágios iniciais de regeneração, temos um acréscimo do número de indivíduos por hectare (densidade), no sentido de evolução do processo de sucessão (regeneração natural). Assim, as maiores densidades são obtidas nas áreas de floresta primária, e, nas áreas de Mata Atlântica, temos, geralmente, densidades superiores a 2.000 indivíduos por hectare (considerando indivíduos com DAP $\geq 5 \mathrm{~cm}$ ). Os estudos fitossociológicos fornecem, então, informações importantes, principalmente, com referência às espécies que serão utilizadas e respectivas densidades e espaçamento de plantio. As informações como frequência mostram as espécies que mais se adaptam na área de forma mais geral e ampla (distribuição mais homogênea nos ambientes presentes na região estudada). A dominância indica as espécies secundárias tardias e clímax, indispensáveis para uso na recuperação ambiental, presentes em áreas florestais nativas similares à original dos ambientes que desejamos recuperar. A experiência prática e os resultados de estudos florísticos mostram a grande importância de se fazer um plantio inicial com maior diversidade possível de espécies na fase inicial, porém sempre levando em conta a necessidade de termos o predomínio de espécies pioneiras na fase inicial de recuperação para áreas abertas.

O TABELA 2 mostra resultados de estudos florísticos e fitossociológicos, realizados no extremo sul da Bahia (ALMEIDA, 2005), no qual podemos observar um aumento de densidade - número de indivíduos por hectare - com a evolução do processo de sucessão, iniciando com 1.344 indivíduos no estágio inicial e aumentando, gradativamente, a densidade até 2.509 indivíduos por hectare, em áreas de floresta primária. Estes resultados mostram que podemos iniciar os trabalhos de recuperação ambiental com espaçamentos variáveis de $7,5 \mathrm{~m}^{2}$ por planta (2,5 x 3 metros, por exemplo) até $6,0 \mathrm{~m}^{2}$ por planta ( 2 x 3 metros, por exemplo). Outra informação 
TABELA 2 - Densidade, área basal, número de espécies e famílias presentes em estudos florísticos e fitossociológicos, realizados no extremo sul da Bahia, englobando diferentes estágios sucessionais de Mata Atlântica (ALMEIDA, 1997)

\begin{tabular}{|l|c|c|c|c|}
\hline & \multicolumn{4}{|c|}{ ESTÁGIOS SUCESSIONAIS DE MATA ATLÂNTICA } \\
\hline \multicolumn{1}{|c|}{ PARÂMETROS } & EI & EM & EA & FP \\
\hline Densidade ( ${ }^{\circ}$ ind./ha) & 1.344 & 1.535 & 2.175 & 2.509 \\
\hline A.B. $\left(\mathrm{m}^{2} / \mathrm{ha}\right)$ & 7,85 & 17,15 & 38,46 & 41,25 \\
\hline $\mathrm{N}^{\circ}$ de espécies & 121 & 182 & 176 & 187 \\
\hline $\mathrm{N}^{\circ}$ de famílias & 42 & 45 & 46 & 46 \\
\hline
\end{tabular}

Fonte: ALMEIDA, 1997

importante é com referência à diversidade de espécies, os estudos fitossociológicos mostram a necessidade de iniciar o processo de recuperação ambiental com uma boa diversidade de espécies, em áreas de estágio inicial de regeneração, já temos presentes 121 espécies botânicas. Observamos que, nos trabalhos de recuperação ambiental, é interessante manter o predomínio de espécies pertencentes ao grupo de espécies pioneiras. Neste estudo, por exemplo, considerando as 10 espécies pioneiras com maior IVI (Índice de Valor de Importância), estas representam $45 \%$ de todas as espécies presentes nesta área, que se apresenta em início de processo de sucessão (ALMEIDA, 2005).

\subsection{Polinização e dispersão de sementes}

Na recuperação ambiental de áreas degradadas da floresta atlântica, como em outras florestas tropicais, é fundamental para o sucesso do projeto o conhecimento das interações planta-animal e da autoecologia das espécies, que estão sendo utilizadas. A eficiência de processos, como a polinização e a dispersão de sementes, realizada principalmente por animais, influencia o estabelecimento das espécies de diferentes estádios sucessionais, e a presença destas populações deve ser considerada no projeto de recuperação. A falta de um agente polinizador, ou dispersor de determinada espécie ou grupo de espécies, pode paralisar o processo de sucessão estagnando-o, principalmente, quando falamos em estágios mais avançados de sucessão, quando as relações plantas-animais ficam mais estreitas, envolvendo um número menor de espécies.

Com base em características morfológicas das unidades de dispersão, podemos classificar as espécies em: 
a. anemocóricas - são aquelas que apresentam estruturas que favorecem o transporte pelo vento;

b. autocóricas - são aquelas que apresentam mecanismo de dispersão por queda livre das sementes;

c. zoocóricas - as que apresentam elementos comestíveis e são procuradas e dispersas por animais;

d. hidrocóricas - que são dispersas via meio aquático.

\subsection{Interação entre flora e fauna}

Acompanhando o processo de mudança de comunidades vegetais, existe também uma fauna característica para cada estágio sucessional, sendo que, nas etapas iniciais, são caracterizados principalmente por polinizadores e dispersores mais generalistas. Na natureza, os dois mutualismos mais importantes, reunindo animais e plantas, são a polinização e a dispersão de sementes. Com o processo de evolução, as plantas desenvolveram mecanismos para atrair animais específicos e, com o avançar da sucessão ecológica, as relações ficam mais estreitas (coevolução) até o ponto de relações bem estreitas entre alguns animais e plantas, isto é, existindo relações mais estreitas, envolvendo um número menor de espécies (em estágios mais avançados de sucessão, como no caso de florestas primárias). Através de cores e odores específicos das flores, as plantas atraem determinados animais ou grupos de animais. No caso de predação de folhas e flores (herbivoria), várias plantas desenvolveram mecanismo para afastar os animais (herbívoros), como exemplo: espinhos, acúleos e sabor das folhas.

Geralmente, o processo da polinização não está diretamente associado às questões de restauração/regeneração. Já a dispersão de sementes está diretamente associada, pois, basicamente, o que se entende por restauração/regeneração é o restabelecimento ou o retorno da vegetação numa área alterada ou sem a sua vegetação original, a partir de sementes ou mudas que foram plantadas nessa área (SILVA, 1999).

Visando mostrar a variação da composição de avifauna, mostramos, na FIGURA 1, a relação de algumas espécies de aves com estágios sucessionais da floresta atlântica do extremo sul da Bahia (floresta ombrófila densa). Este grupo de espécies é um excelente bioindicador de evolução do processo sucessional. 
FIGURA 1 - Variação da composição da avifauna relacionada com estágio sucessional da floresta atlântica do sul da Bahia

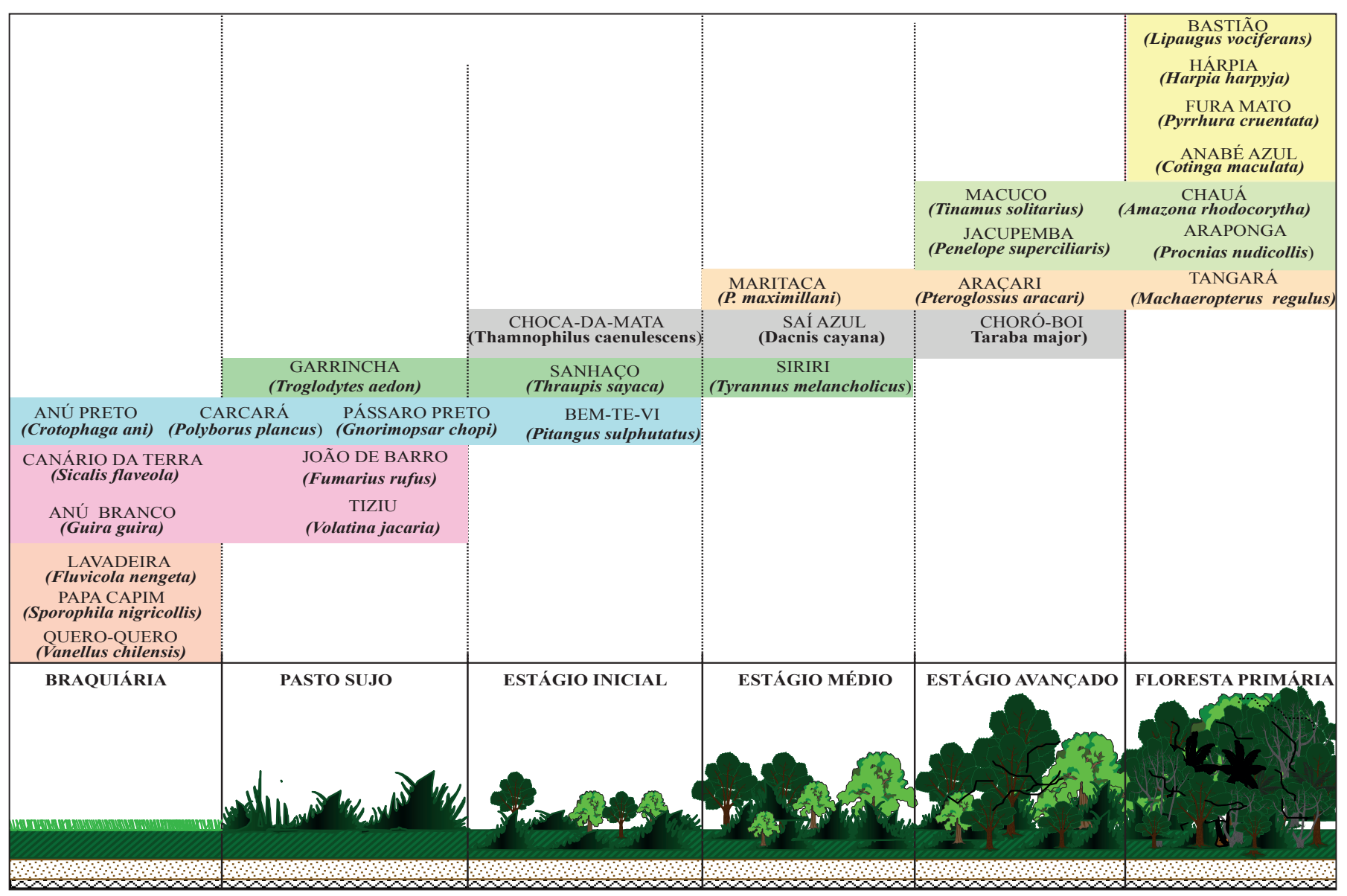


Em estágios secundários, também é alta a taxa de zoocória, Janzen e Vazquez-Yanes (1991) afirmam que os animais são responsáveis pela dispersão de mais de $75 \%$ das espécies nas florestas tropicais ricas em espécies, também Morellato e Leitão-Filho (1992), trabalhando em área de floresta atlântica (Serra do Japi), citam que de 60 a 90\% das espécies da floresta são de dispersão zoocórica. Estudos desenvolvidos, nas áreas de floresta atlântica, mostram uma grande participação de animais na síndrome de dispersão de frutos e sementes. Costa et al. (1992), estudando um total de 227 espécies arbóreas, registraram 74\% das espécies dispersas por animais (contra $24 \%$ por anemocoria e $4 \%$ por autocoria), também Mathes (1980), em estudo envolvendo 165 espécies de floresta atlântica, situada em Campinas, estado de São Paulo, encontrou 69,70\% das espécies zoocóricas (contra 23,64\% anemocóricas e 6,66\% autocóricas). Podemos concluir, baseados nas pesquisas realizadas, que a sucessão, em áreas de florestas tropicais, depende da ação dos agentes dispersores bióticos. A recuperação e o manejo destas áreas terão que considerar as interações entre populações de animais e de plantas.

Também no processo de polinização é grande a interação entre plantas e animais (principalmente insetos). Estudos desenvolvidos em florestas tropicais (BAWA et al., 1985) no México, onde foram amostradas 143 espécies arbóreas, mostram uma grande participação dos insetos no processo de dispersão, mais de 90\% (abelhas médias e grandes, 27,5\%; abelhas pequenas, $14 \%$; mariposas, $15,8 \%$; besouros, 7,3\%; borboletas, 4,9\%; outros insetos, 20,8\%), participando ainda beija-flores com $4,3 \%$, morcegos com $3 \%$ e o vento com $2,5 \%$.

O processo de dispersão de sementes é de fundamental importância para a sustentabilidade de uma área que está em recuperação ambiental, considerando que cerca de 50 a 90\% das espécies de árvores, nas florestas tropicais, são dispersas por animais (HOWE; SMALLWOOD, 1982). Complementarmente temos algumas considerações sobre este processo:

a. a dispersão de sementes é feita geralmente por animais vertebrados, representados principalmente por aves e mamíferos, grupos mais bem adaptados à dispersão de sementes de angiosperma;

b. espécies clímax são geralmente dispersas por animais de porte maior, o que constitui um grande problema 
considerando o caso da Mata Atlântica, onde temos poucas áreas em que há ainda a ocorrência de mamíferos de grande porte;

c. os frutos, utilizados como alimento por esses animais, geralmente são bagas e drupas carnosas ou suculentas, e os animais são atraídos para estes frutos por estímulos visuais (cores chamativas e contrastantes) ou olfativos (odores fortes), dependendo do agente dispersor considerado (SILVA, 1999).

d. a recompensa nutricional, que os frugívoros "recebem" pelo serviço prestado na dispersão de sementes, compõe-se basicamente de carboidratos e lipídeos, distribuídos em proporções desiguais entre as várias espécies e tipos de frutos. Algumas famílias de plantas investem caracteristicamente em um ou outro desses componentes e, assim, conseguem selecionar diferencialmente frugívoros em função de suas preferências alimentares (JORDANO, 1992).

e. mesmo considerando que frutos são "presas" imóveis para vertebrados frugívoros, nem todas as plantas apresentam o mesmo grau de acessibilidade a seus recursos alimentares. Frutos podem estar dispostos de diferentes maneiras na arquitetura da planta, permitindo o acesso somente das espécies com aparato morfológico-comportamental adequado à sua exploração. Assim podemos observar que os frutos dispersos por morcegos, por exemplo, estão dispostos na arquitetura da planta ou junto ao caule ou galhos, isto é, dispostos fora da folhagem da planta à qual os morcegos não teriam acesso. Também frutos em posição pendente e destacada na copa da planta podem ser comparativamente mais visitados por aves com habilidade para pegar alimento por meio de diversas manobras aéreas, do que por aves que necessitam estar pousadas em poleiros horizontais para se alimentarem (SILVA, 1999).

f. existem na natureza espécies-chave que se alimentam de várias espécies de animais. Geralmente elas alimentam os animais no período de escassez de alimento nos ambientes. Como exemplo, citamos a jussara ou palmito (Euterpe edulis) que serve de alimento para várias espécies animais. 
g. a abertura de clareiras facilita o acesso de aves e morcegos frugívoros que frequentam estas áreas presentes no interior da floresta, estas espécies vão depositar sementes que serão incorporadas ao banco de sementes, ou germinarão prontamente, sob as condições mais intensas de luminosidade (SILVA, 1999).

h. por possuírem o hábito de defecar enquanto estão empoleiradas, as aves tendem a depositar mais sementes na periferia desses espaços abertos, onde a disponibilidade de poleiros é maior. Já os morcegos, pelo hábito de defecarem durante o voo, geram uma chuva de sementes mais intensa no interior das clareiras, um espaço geralmente mais livre de obstáculos em seu deslocamento (GORCHOV et al., 1993).

O conhecimento sobre os principais dispersores de plantas de florestas tropicais pode favorecer a regeneração natural de áreas, em processo de regeneração, com a adoção de determinadas práticas e informações. A proximidade de um fragmento florestal (fonte de sementes) pode facilitar e garantir o fluxo de dispersores na área em recuperação, além de constituir a fonte de sementes. Também, no plantio de mudas realizadas, priorizar o plantio de plantas zoocóricas e, preferencialmente, plantas precoces, que florescem e frutificam rapidamente (algumas espécies frutificam em menos de 1 ano após o plantio). A introdução de poleiros artificiais é outra prática que pode ser adotada para melhorar a frequência de dispersores na área, que está em recuperação.

\subsection{Mecanismos de sucessão e regeneração natural}

As espécies da floresta tropical se regeneram através de diversos mecanismos como banco de sementes do solo, chuva de sementes, banco de plântulas e brotações. Estes diferentes caminhos garantem a autorrenovação, a sustentabilidade e a manutenção da diversidade biológica destes ecossistemas.

A queda de árvores dentro de uma floresta provoca a presença de clareiras, estimulando a entrada de espécies (ativando banco de sementes e banco de plântulas) provocando alteração (normalmente 
aumento) da diversidade de espécies daquele fragmento. Assim, em grandes fragmentos florestais, a queda de árvores e a abertura de clareiras (pequenos distúrbios) motivam o processo de sucessão dentro destas áreas florestais. A presença de pequenas clareiras, normalmente, pela quantidade de luz que é passada, ativa o banco de plântulas, enquanto as grandes clareiras ativam o banco de sementes do solo, espécies que necessitam de temperatura (espécies pioneiras termoblásticas) e luminosidade para sua germinação (espécies pioneiras fotoblásticas). O entendimento da dinâmica da floresta tem grande importância na restauração florestal, o conhecimento destes mecanismos e a autoecologia destas espécies são fundamentais para o desenho de modelos de restauração ecológica de ecossistemas.

\subsubsection{Banco de Sementes do Solo}

O banco de sementes do solo é composto pelas sementes viáveis, em estado de dormência real ou imposta, presentes na superfície ou no interior do solo de determinada área. O banco de sementes pode ser caracterizado como a quantidade de sementes existentes no solo, num dado momento e numa dada área, constituindo um sistema dinâmico de entradas e saídas (KAGEYAMA, 1987). O banco de sementes do solo é formado por sementes produzidas na área, assim como sementes transportadas de outros locais, mantendo-se viáveis por menos de um ano (banco de sementes transitório) ou mantendo a viabilidade por mais de um ano (banco persistente, composto principalmente pelas espécies pioneiras), ambas em estado de dormência (MARTINS, 2012). O banco de sementes no solo abriga, basicamente, sementes de espécies pioneiras (mais duradouras e persistentes) e secundárias iniciais, sendo fator essencial para que haja a regeneração da primeira fase de ocupação e cicatrização de clareiras grandes (WHITHMORE, 1988). As espécies não pioneiras, em geral, germinam logo depois de dispersadas e vão compor o banco de plântulas, outro componente da regeneração natural.

O estudo do banco de sementes do solo, em um determinado ecossistema, florestal é importante no fornecimento de dados sobre a dinâmica do processo de regeneração natural. A ativação do banco de sementes do solo se dá após perturbações no ecossistema: uma simples queda de árvore, abertura de uma pequena clareira na floresta ou distúrbios maiores, como abertura de grandes 
clareiras e desmatamentos. Estes impactos criam condições para que as sementes estocadas entrem em atividade e repovoem a área perturbada. O banco de sementes possui estoque variável, conforme entradas e saídas de sementes e outros propágulos, o estudo deste fluxo de propágulos é de grande importância, quando pretendemos o melhor entendimento da dinâmica do banco de sementes do solo. Segundo Leal Filho (1992), o conhecimento do banco de sementes em relação a seu tamanho, composição florística, padrão de distribuição de sementes no solo, assim como sua dinâmica, é fator importante na compreensão dos mecanismos que controlam a sucessão vegetal nos trópicos. Este autor menciona que o banco de sementes possui uma parte ativa, representada pelas sementes que se encontram em estado de dormência imposta pela falta ou deficiência de algum fator, nos níveis necessários a sua germinação (umidade, luz, temperatura), sendo este grupo representado principalmente pelas espécies pioneiras, que mantêm sua viabilidade prolongada mesmo sob as condições de elevada umidade no solo da floresta (ex.: Embaúba - Cecropia - até 62 meses).

A autorrenovação da floresta é assegurada pela existência do banco de sementes no solo, e a sua ativação pode proporcionar um aumento de biodiversidade do ecossistema. Assim, constitui o banco de sementes no solo um importante componente da regeneração natural, principalmente, no que diz respeito à regeneração de clareiras, bordas da mata e áreas desmatadas. O uso indiscriminado do fogo, prática comum em algumas regiões brasileiras, pode aniquilar completamente o banco de sementes do solo, anulando a ação deste meio biótico de regeneração.

Do ponto de vista de diversidade, o banco de sementes do solo pode conter uma variação específica e genotípica distinta da encontrada no dossel arbóreo já existente. Áreas de floresta atlântica mostram, geralmente, um alto potencial de regeneração, apresentando após impacto um grande número de plântulas por hectare. Vários autores, citados por Leal Filho (1992), avaliaram o potencial de regeneração de áreas em função da presença de espécies pioneiras no banco de sementes. O número de sementes por metro quadrado pode variar bastante, conforme referências, o número pode variar de menos de 100 sementes por metro quadrado (floresta primária) até em torno de 25.000 sementes por metro quadrado, conforme encontrado por Santarelli (1989), em trabalho desenvolvido 
em área recém-desmatada, no município de Ilha Solteira, estado de São Paulo. Também Carpanezzi e Laurent (1989), pesquisando a regeneração natural da bracatinga, no estado do Paraná, encontraram 20.220 plântulas por hectare, cinco meses após os distúrbios, mostrando o grande potencial de regeneração de áreas em estágios mais iniciais de sucessão. Notamos que, quanto mais avançado o estágio sucessional, menor o potencial de regeneração da área. Teoricamente, áreas de floresta secundária teriam maior potencial de regeneração do ponto de vista de banco de sementes.

Quanto a sua composição, Leal Filho (1992), em trabalhos desenvolvidos em formações secundárias (Viçosa), observou a ausência de sementes representativas de floresta primária no banco de sementes do solo. Este autor relata que a ausência deste grupo de espécies está associada ao curto período de viabilidade de suas sementes e pela incapacidade das sementes entrarem em dormência. A presença destas espécies está também condicionada à presença de matrizes na área em questão ou proximidades. Já as sementes de espécies pioneiras, por apresentarem como principais características a dormência, na presença de características desfavoráveis à germinação, e maior durabilidade no piso da floresta permanecem em estoques no banco de sementes. A composição do banco de sementes vai depender, portanto, da existência de espécies pioneiras, capazes de dispersar grandes quantidades de sementes que se mantêm viáveis no solo da floresta por longo tempo.

Da mesma forma, a presença de dispersores de sementes, fundamentais para levar as sementes de áreas remanescentes de florestas primárias, em estágios avançados de sucessão, para as áreas vizinhas em processo inicial de regeneração, pode comprometer todo processo sucessional. Muitos fragmentos florestais, em estágios iniciais e médios de regeneração, estão hoje estagnados do ponto de vista sucessional por não possuírem propágulos de espécies secundárias tardias e clímax, que seriam as responsáveis pelo prosseguimento do processo sucessional natural. Esta interrupção do fluxo de propágulos entre duas áreas florestais pode ocorrer devido à ausência do dispersor original na região, distância entre fragmentos, ausência de população de espécies secundárias tardias e clímax nos fragmentos florestais da região, ou uma conjunção destes fatores.

A composição do banco de sementes vai refletir a distribuição florística das espécies dos diversos estratos da floresta, assim 
como a idade da floresta e o estágio sucessional em que esta se encontra. Do mesmo modo, a produção de sementes, os períodos de viabilidade e dormência, os processos de dispersão, a competição, a predação, a existência de fontes de propágulos, vão influenciar no estoque de sementes do solo.

Quanto ao período de permanência no banco de sementes do solo, Janzen e Vasques-Yanes (1991) mencionam exemplos de árvores do gênero Ficus e Chlorophora, que apresentam dormência por poucos meses, e Cecropia que possui sementes pequenas e dormentes, que requerem um aumento de luz, e, muitas vezes, temperatura para germinar e podem permanecer dormentes por 1-2 anos, se não forem predados por animais ou fungos.

Em contraste com as sementes de pioneiras, a maioria das sementes de espécies da floresta tropical primária não possui dormência e sim um pequeno tempo de vida. Elas geralmente germinam logo após serem dispersas, por perderem rapidamente a viabilidade. Quanto ao tamanho das sementes presentes no banco, observa-se que as sementes maiores são mais facilmente predadas por animais.

Uma maior amplitude de variação na temperatura do solo entre o dia e a noite ou uma maior incidência de luz do espectro vermelho podem ativar o banco de sementes, pois as espécies pioneiras tendem a responder a estímulos de luz e de temperatura, sozinhos ou separados, ativando a germinação destas espécies. Assim, o histórico de perturbações da área degradada vai influenciar na sequência sucessional, ou seja, dependendo do distúrbio, que afeta a área em questão, um determinado grupo de espécies vai encontrar melhores condições para estabelecimento.

O conhecimento do banco de sementes do solo permite que sejam feitas várias inferências sobre o processo de regeneração natural, assim como a adoção de técnicas de manejo para conservação da diversidade biológica ou recuperação de áreas.

Nem sempre áreas degradadas isoladas têm alta resiliência, áreas antropizadas por um longo período de tempo (como exemplo grandes áreas de pastagem ou áreas de cultivo agrícola), isolado de áreas florestais, normalmente não possuem banco de sementes expressivo pelo tempo de isolamento e cultivos de pastagens, ou culturas agrícolas por longo tempo. Este isolamento de áreas em que são desenvolvidas atividades agropecuárias pode inibir mecanismos de regeneração como a chuva de sementes e consequente entrada 
de propágulos nestas áreas, normalmente de grande extensão, resultando em locais de baixa ou nenhuma resiliência e capacidade de regeneração natural.

\subsubsection{Banco de plântulas}

Constituem o banco de plântulas da regeneração natural todas mudas que se encontram, no piso da floresta, com altura a partir de $0,10 \mathrm{~cm}$ e diâmetro até o limite estabelecido no levantamento natural (FINOL, 1971). Em muitos estudos, o ingresso da plântula é considerado a partir da germinação das sementes, isto é, todas as plantas arbóreas, existentes até o diâmetro mínimo, estabelecido no inventário dos demais estratos da floresta. A distribuição das espécies nos diferentes estratos da floresta, assim como a presença/ ausência na regeneração natural, podem dar indicativos de tolerância, comportamento, participação das espécies em outros estádios serais, presença ou ausência de agentes polinizadores e dispersores, e permanência da espécie em questão no sistema.

Diversos fatores externos influenciam o crescimento de uma árvore, Souza e Leite (1993) citam que luz, temperatura, água, nutrientes e $\mathrm{CO} 2$, como os principais, e a quantidade disponível destes elementos para as plantas é regulada pela densidade de árvores existentes nos estratos superiores da floresta. A regeneração natural é grandemente afetada por estes fatores, a disponibilidade destes elementos mais a competição, a presença de predadores (taxa de herbivoria), os microrganismos de solo como micorrizas e fungos vão determinar quais espécies vão sobreviver e ocupar o seu lugar nos dosséis superiores do ecossistema florestal.

Destacamos que no período entre germinação das sementes e estabelecimento de plântulas existe um intenso processo de herbivoria, limitando a densidade populacional das espécies, que vão compor o banco de plântulas.

\subsubsection{Chuva de sementes}

Uma das condições fundamentais para a eficiência dos processos de regeneração natural é a existência de uma fonte de sementes próxima à área degradada. A proximidade de um fragmento 
florestal, e o consequente acesso à chuva de sementes, pode facilitar todo processo de regeneração natural. Esta proximidade é relativa, visto que, muitas vezes, a regeneração natural não é expressiva por falta de matrizes de determinadas espécies e presença de dispersores de sementes. Portanto a distância entre fragmento florestal e área degradada é ponto importante na regeneração natural. Em paisagens muito antropizadas, a chuva de sementes contribui pouco para a sucessão florestal (MARTINS, 2012), são áreas que possuem baixa resiliência.

\subsubsection{Rebrota de cepas}

Rebrota de cepas, geralmente, não é uma forma de regeneração natural muito eficiente, sendo pouco considerada, mas, em muitos casos, como, por exemplo, nas áreas recém-desmatadas - corte raso sem destoca - pode representar uma das principais formas de regeneração natural. Muitas espécies apresentam como estratégias de permanência, em determinado sistema, a perpetuação por muito tempo de seu sistema radicular. Esta "dormência" propicia resistência ao fogo, à luz solar direta e a outros impactos. Touças de biriba (Eschweleria ovata), no sul da Bahia, sobrevivem a grande número de impactos e se regeneram, tornando-se comum em áreas com alta densidade desta espécie na região. É comum esta espécie se apresentar presente em regeneração até mesmo em áreas "destocadas" com uso de trator de esteira.

A rebrota de cepas tem mostrado ser uma estratégia interessante de condução principalmente em locais onde existem densidades significativas de espécies que se regeneram a partir das touças/cepas.

\subsection{Aplicação de princípios da sucessão ecológica na restauração}

Grande parte das técnicas utilizadas na restauração ecológica vem das observações dos processos naturais de sucessão e autoecologia e comportamento das espécies. O diagnóstico bem feito das condições atuais do terreno, a perfeita seleção de espécies nativas para início da restauração, o espaçamento, a diversidade de espécies e a proporção de plantio são definições importantes para 
a restauração de áreas degradadas. Hoje sabemos que a sucessão ecológica, diferente do que se pensava inicialmente, na teoria holística da sucessão, descrita por Clements, em 1916 (citado por MARTINS, 2012), não funciona como um mecanismo previsível, unidirecional e progressivo, e nem sempre segue para um estado clímax único. Hoje sabemos que, nem sempre, a sucessão segue para um estado idêntico ao original, sendo influenciada sempre por muitos fatores externos que conduzem para um processo que pode seguir várias trajetórias. Conforme mencionado por MARTINS (2012), no processo de restauração ecológica, não é exigido um estado clímax a ser atingido, as metodologias atuais apresentam em comum o enfoque na restauração da diversidade vegetal, funções e processos ecológicos dos ecossistemas, sem a preocupação com o clímax a ser alcançado. Estes princípios da sucessão são de extrema importância na seleção de espécies para uso em restauração ecológica, a sequência sucessória e espécies pioneiras típicas de cada ecossistema e dentro destes, típica de cada ambiente (alto de morro, matas ciliares, encostas com exposição para o sul, encosta com esposição para o norte, áreas úmidas etc.) serão primordiais para o sucesso do processo de restauração ecológica de uma área degradada/pertubada. Mesmo não atingindo um estado clímax idêntico ao original, a utilização correta das espécies irá promover a integração entre o componente vegetal e outros do ecossistema que estão sendo restaurados. No Brasil, destacamos iniciativas de restauração de matas ciliares, onde já existe esta preocupação de reproduzir a sucessão destes ambientes ciliares, utilizando somente espécies adaptadas às condições das florestas ripárias.

\subsection{Espécies exóticas invasoras e suas interferências na restauração ecológica}

A grande infestação de espécies exóticas invasoras em várias regiões do planeta e, principalmente, em algumas regiões brasileiras (em especial na Mata Atlântica, nas áreas de restinga) tem interferido muito nos trabalhos de conservação e restauração ambiental. A presença destas espécies causa um desequilíbrio no ecossistema e altera completamente o curso normal da sucessão ecológica. A introdução e a presença de espécies exóticas que são adaptadas às outras condições 
ecológicas provocam uma competição com as espécies nativas na qual as espécies exóticas levam vantagem na concorrência com as espécies nativas regionais no que se refere a aspectos como a dispersão, a propagação, a resistência a pragas e as doenças. Pela ausência de inimigos naturais e, muitas vezes, a reprodução acelerada (ciclos contínuos de floração e frutificação), e dependendo do tipo de propagação, estas espécies exóticas invasoras podem ocupar grandes áreas naturais e alterar completamente o ecossistema natural presente. Em algumas áreas, a invasão de espécies exóticas descaracteriza completamente o ecossistema natural, aonde esta entrada de espécies exóticas invasoras chega a ocupar praticamente toda a área natural.

Na FOTO 4, podemos observar invasões de espécies exóticas invasoras leucena (Leucaena leucocephala) e amendoeira (Terminalia catappa L.) em área de restinga no município de Porto Seguro, Bahia. Na orla norte deste município, temos casos de espécies exóticas invasoras substituirem praticamente toda a vegetação da restinga original, que recobria a faixa de areia próxima à praia.

\subsection{Considerações sobre aspectos genéticos}

Considerando o estado atual da floresta atlântica, em sua maior parte reduzida a pequenos fragmentos, muitas vezes isolados, a compreensão de aspectos genéticos e da autoecologia das espécies torna-se fundamental, quando pensamos em conservação e recuperação deste bioma. Fragmentos florestais em ecossistemas como a floresta atlântica são redutos de diversidade biológica, e desempenham importante papel, contribuindo como importantes repositórios de material genético para programas de recuperação e manejo destes ecossistemas. No entanto a área, forma, histórico de perturbações e outros fatores podem interferir nestes fragmentos, a ponto de sua importância para conservar amostra representativa da biodiversidade seja questionada. Fragmentos também sofrem constantemente danos referentes a incêndios, caça ilegal e exploração madeireira extrativista, o que muito interfere e diminui sua diversidade biológica e variabilidade.

A diversidade genética ou a variabilidade, devido à diferença nos alelos, pode ocorrer em diferentes níveis: a) de espécies dentro de ecossistemas; b) de populações dentro de espécies; e c) de indivíduos dentro de populações da espécie (KAGEYAMA, 1987). 
FOTO 4 - Presença de espécies exóticas amendoeira (Terminalia catappa L.) e Leucena (Leucaena leucocephala ) em área de restinga, orla norte do município de Porto Seguro, Bahia

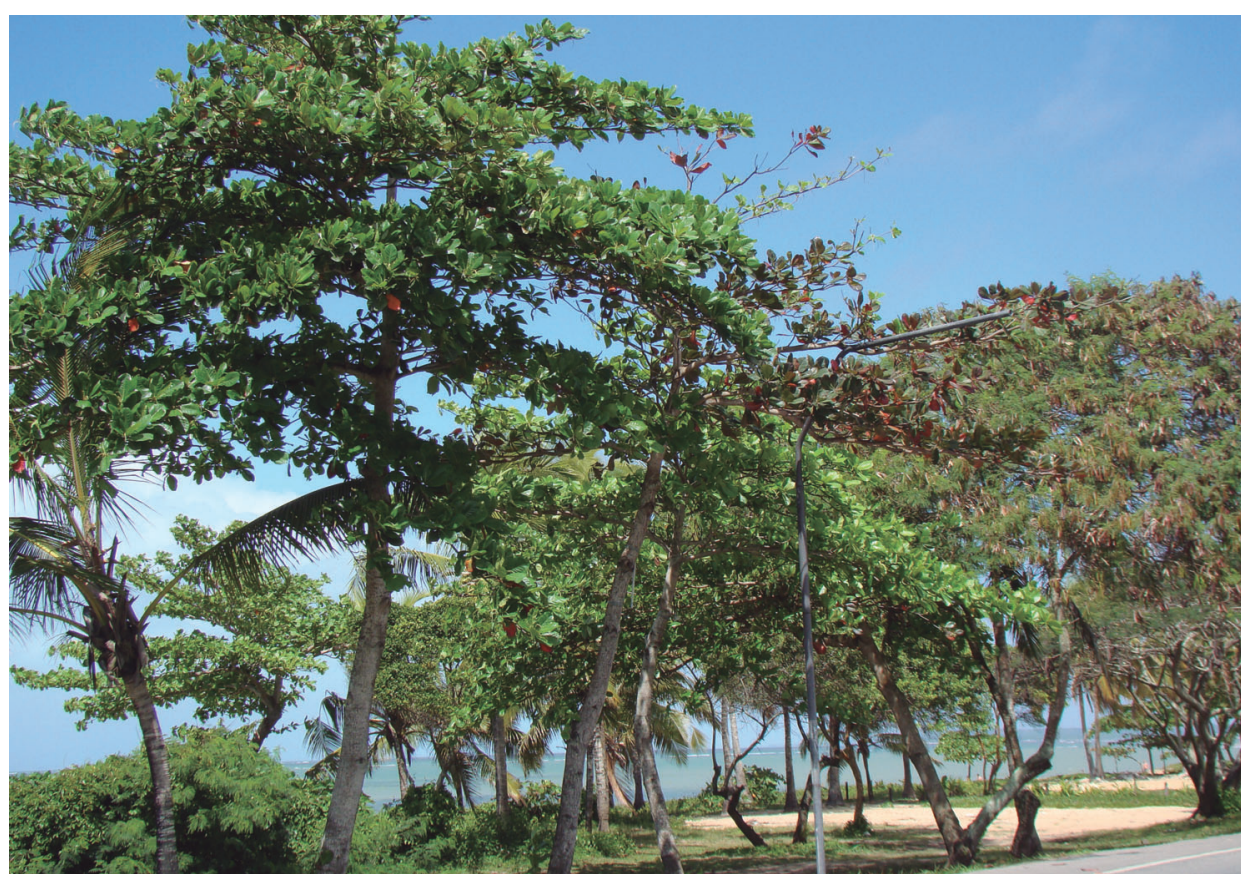

FOTO 5 - Invasão de espécies exóticas amendoeira (Terminalia catappa L.) em área de restinga herbácea e arbustiva, orla norte do município de Porto Seguro, Bahia

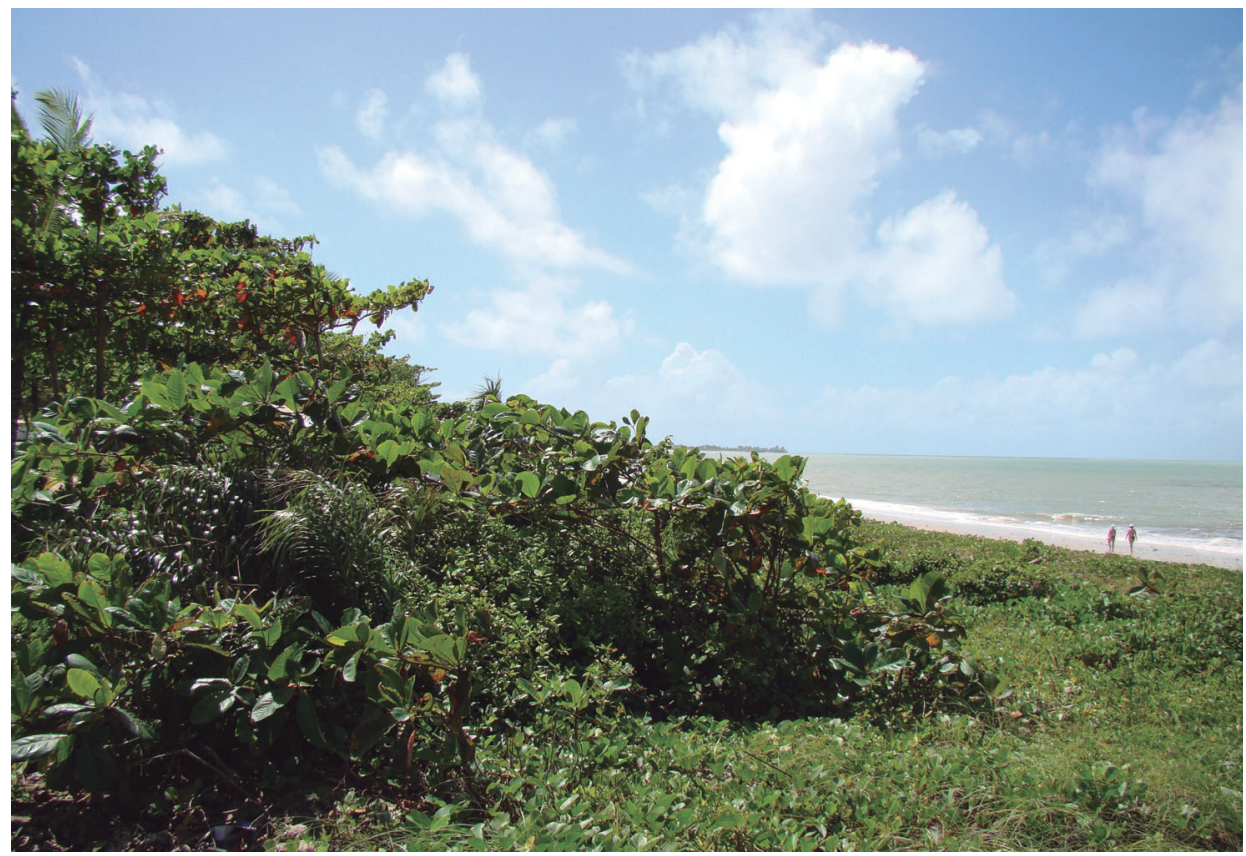


Do ponto de vista genético, o isolamento de pequenos trechos florestais e a presença de pequenas populações de determinadas espécies podem ocasionar sérios problemas de endogamia, determinando uma decadência (falha) genética (devido a menor variabilidade genética). Entre os grupos de espécies mais ameaçados, do ponto de vista de diversidade genética, estão as espécies raras. Este grupo é representado por um pequeno número de indivíduos por área, exigindo, portanto, grandes áreas para manter uma base genética mínima e garantir sua perpetuidade.

O conhecimento da autoecologia das espécies, agentes polinizadores e dispersores, tipos de flores e frutos, ciclo de vida e outras informações são importantes do ponto de vista de manejo visando à conservação da diversidade destas espécies.

Podemos observar a ausência de espécies secundárias tardias e clímax que, frequentemente, são espécies raras em pequenos fragmentos, muitas vezes por extrativismo vegetal intenso, outras vezes por caça e eliminação de dispersores de sementes. Esta situação pode ser objeto de um manejo ambiental, visando ações de plantios de enriquecimento, buscando resgatar as densidades originais destas

FOTO 6 - Espécie pioneira (Schinus terebentifolius.) no município de Barbacena, estado de Minas Gerais, em altitude superior a 1.500 metros, mostrando a adaptabilidade desta espécie a ocorrer em diferentes ambientes

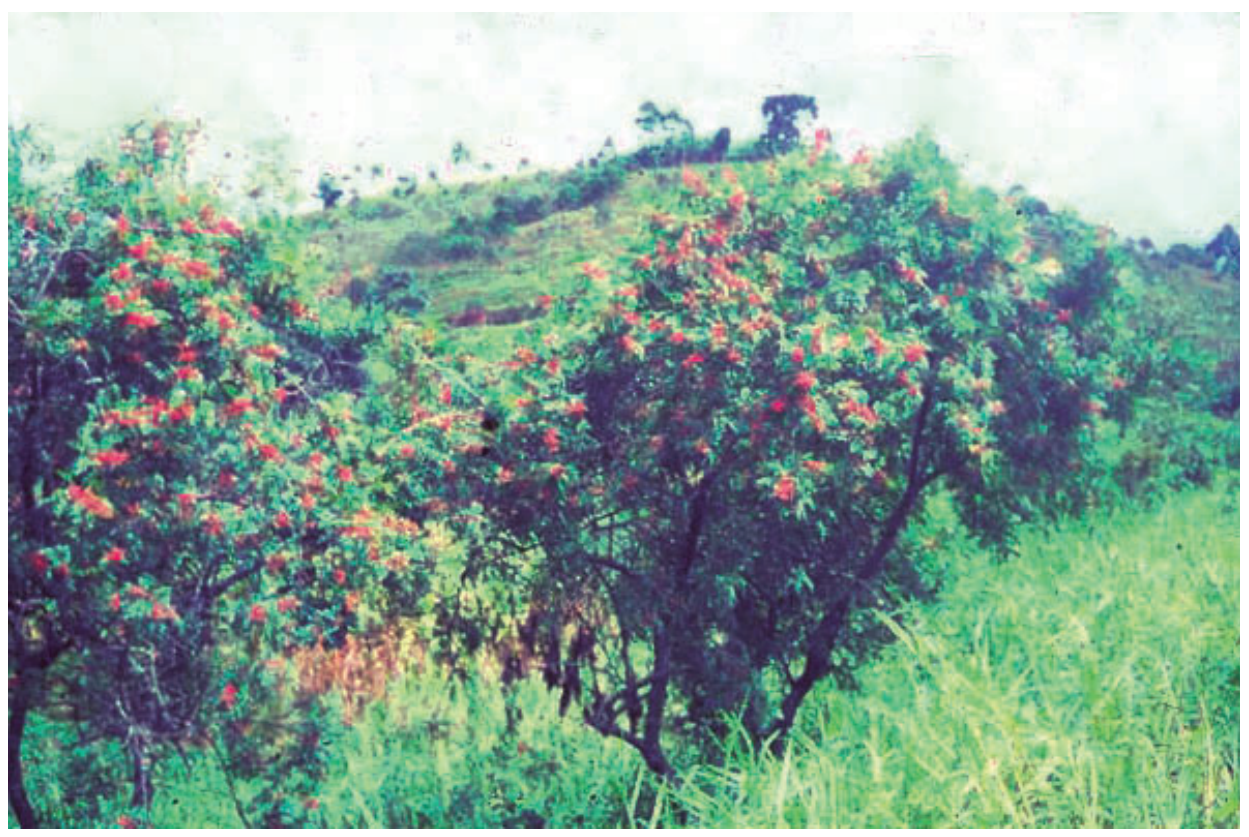


espécies, daí a importância de estudos florísticos e fitossociológicos em ecossistemas de floresta atlântica primários, pois são fontes de referência para futuros trabalhos de enriquecimento.

Muitos fatores influenciam e condicionam o fluxo gênico dentro de populações de plantas, como, por exemplo, a grande variedade de sistemas reprodutivos, seu conhecimento é fundamental para o entendimento da estrutura da população.

Considerando a grande interação existente entre elementos da flora e fauna na floresta atlântica, assim como o grande grau de interferência antrópica neste ecossistema, podemos dizer que muitos animais polinizadores e dispersores já foram extintos, comprometendo a composição genética de várias espécies e levando muitas outras ao desaparecimento. A polinização é uma forma de aumentar ao máximo o fluxo gênico e permitir com isso sua sobrevivência (JANZEN, 1980).

Do ponto de vista prático, em recuperação de áreas degradadas, no caso da Mata Atlântica, onde temos a ocorrência das espécies nativas em populações superfragmentadas e distribuídas ao longo de uma grande amplitude de temperatura, precipitação, altitude, solos, tipos de vegetação, o ideal é que façamos a coleta de sementes florestais sempre próximos à área a ser recuperada, considerando que estas espécies estão adaptadas às condições ecológicas locais e transmitem, geneticamente, esta adaptação às sementes. 


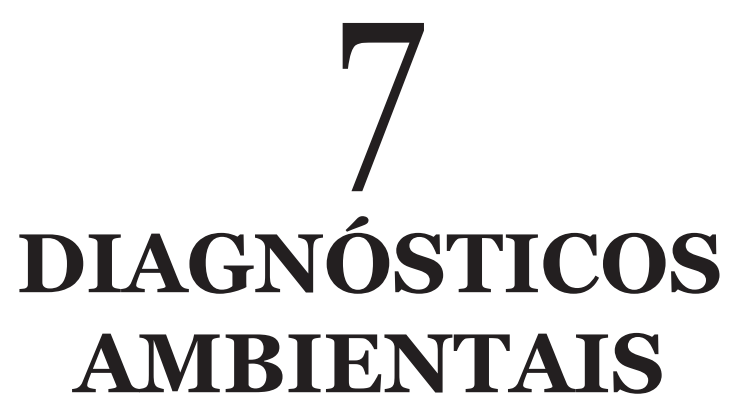




\subsection{Identificação e avaliação da série histórica de impactos}

ara o processo de recuperação de áreas degradadas, é im-
portante o conhecimento do histórico de perturbações da
área degradada, este conhecimento auxilia no delineamento de estratégias. Levantamentos históricos, revisões bibliográficas, referências sobre a vegetação original, conhecimento sobre a fauna existente na região, características e impactos sobre o solo, hidrografia e alterações nos cursos de água, atividades antrópicas (desmatamento, utilização de fogo, retirada de camadas superficiais do solo, introdução de espécies exóticas) são importantes para a definição de métodos de recuperação ambiental de áreas degradadas.

Como estratégias para se obter estas informações, são utilizadas, normalmente, entrevistas (antigos proprietários, proprietário atual, vizinhos, antigos moradores, entre outros), levantamentos em bibliotecas locais, comparação com áreas vizinhas, enfim, registros históricos documentais e fotográficos.

\subsection{Meio físico}

\subsubsection{Aspectos climáticos}

Os aspectos climáticos compreendem informações referentes à precipitação e sua distribuição ao longo do ano, déficit hídrico, temperaturas máximas, mínimas e médias anuais, e umidade relativa. Em caso de programas de recuperação, envolvendo grandes áreas e um longo tempo de implantação, caso não tenhamos nenhuma informação climática, é necessário a montagem de uma pequena estação (ou confiar na informação de moradores locais).

Para projetos envolvendo pequenas áreas, informações coletadas em estação meteorológicas da região são suficientes para tomada de decisões. As principais implicações das informações sobre aspectos climáticos são a respeito de: seleção de espécies a ser utilizada, época ideal de plantio, época ideal para realização de obras de engenharia e desenho de modelos apropriados de recuperação. 


\subsubsection{Levantamentos edáficos}

Para a execução dos levantamentos edáficos, deve-se dispor de uma referência cartográfica (planta da propriedade ou fotografias aéreas), na qual serão delimitadas as diferentes manchas de solos. Através de exame in loco, poderá ser observada uma série de características do solo que somada às análises químicas (principalmente NPK, micronutrientes, acidez, capacidade de troca catiônica, Al) e às análises físicas (principalmente para solos compactados e muito alterados) fornecerá informações básicas para subsidiar o projeto.

Estas informações vão subsidiar principalmente: preparo do terreno, necessidade de aração, gradagem, sub-solagem, coveamento e em quais dimensões, quantidade e formulação de adubação, necessidade de correções (calagem) e seleção de espécies apropriadas para aquele tipo de solo (ambiente).

\subsubsection{Relevo}

Em função do tamanho da área que desejamos recuperar, existe a necessidade da confecção de uma planta planialtimétrica, contendo pontos de maior declividade e áreas, onde são necessárias

FOTO 7 - Exemplo de área degradada por atividade agropecuária, necessitando de bons diagnósticos prévios para definir tratamentos de recuperação

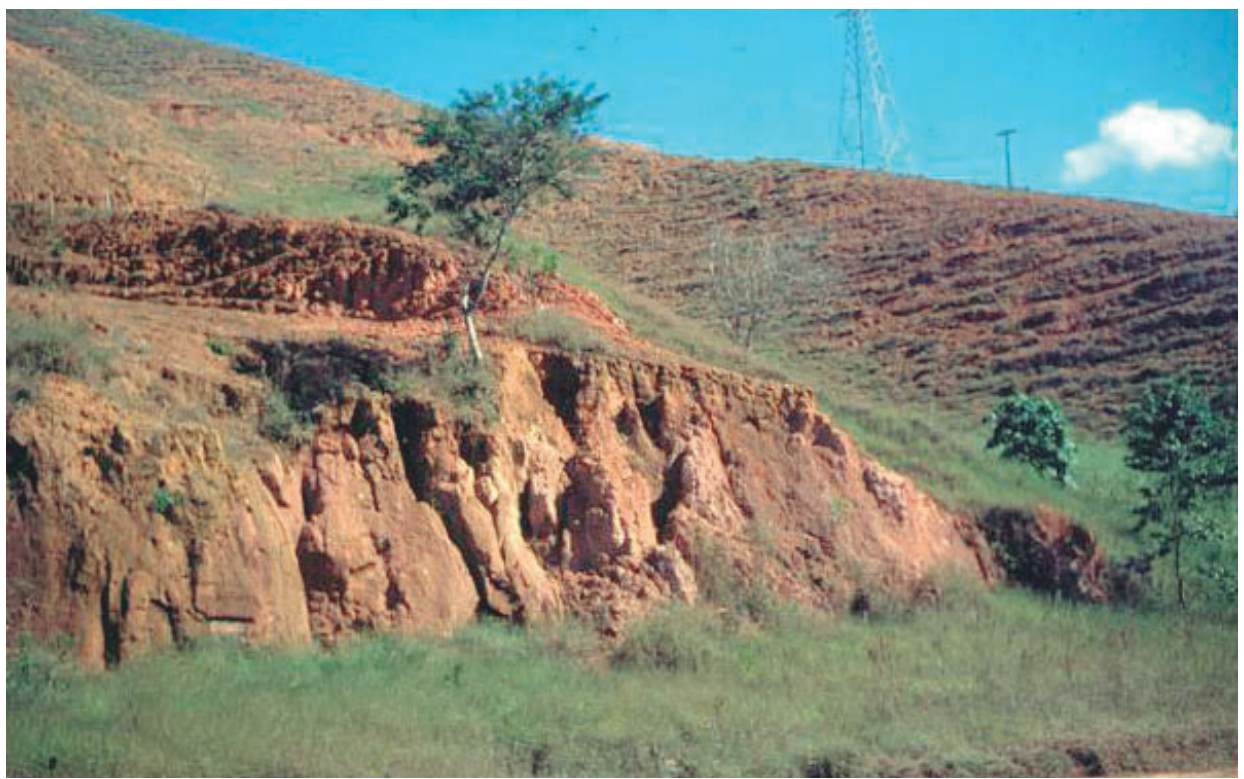


obras de engenharia e reafeiçoamento do terreno. Principalmente projetos cuja finalidade principal é a contenção de encostas - recuperação de áreas em taludes de estradas e mineração - deve-se ter o conhecimento do relevo e da resistência do solo às intempéries.

O relevo influencia uma série de fatores, como por exemplo: a escolha de espécies e espaçamento a ser utilizado (necessidade de adensamento nas áreas de maior declive e maior risco de deslizamento), necessidade de plantio de gramíneas e herbáceas, utilização de telas ou combinação de outros métodos de contenção e revegetação, além da necessidade da implantação de outras obras de engenharia.

\subsubsection{Recursos hídricos}

Devem ser bem conhecidas a rede hidrográfica original e a área de influência da bacia hidrográfica que está sendo trabalhada. Diagnosticar qual nível de degradação - erosão e assoreamento - da área, que está sendo reabilitada, e a situação atual dos cursos de água, assim como o uso do corpo de água a jusante da degradação.

Nos trabalhos de recuperação de matas de galeria (ciliares), deve-se tomar como unidade de planejamento a bacia hidrográfica a ser trabalhada. Estas informações vão auxiliar na definição da necessidade de obras de dragagem, construção de drenos, muretas e canaletas, definição de modelos específicos para recuperação de matas de galeria, nascentes e topos de morro.

\section{7•3 Meio Biótico}

\subsubsection{Estudos florísticos e fitossociológicos}

Faz-se necessário, principalmente, quando se pretende recuperar aspectos ambientais e recompor a vegetação o mais próximo possível da original, termos uma boa referência da flora regional. Considerando que existe uma composição florística típica de cada estágio sucessional, as áreas referenciais devem contemplar, quando possível, todos os estágios sucessionais, permitindo conhecer a composição florística e a estrutura típica de cada estágio sucessional. Na função do tamanho da área a ser recuperada, bem como dos prazos de entrega dos projetos de recuperação, devem ser definidos 
a abrangência e o nível de amostragem dos levantamentos referenciais a serem realizados. Grandes programas de manejo ambiental e recuperação exigem levantamentos florísticos e fitossociológicos detalhados, abrangendo áreas em diferentes estágios de sucessão ecológica (estágio inicial, estágio médio, estágio avançado e floresta primária), de fragmentos florestais existentes na vizinhança da área degradada. Para o desenho de modelos de recuperação para pequenas áreas, muitas vezes, somente diagnósticos rápidos e observação de vegetação pioneira da região podem atender às necessidades iniciais do projeto. Destacamos a importância do conhecimento dos diferentes estratos da vegetação (herbáceo, arbustivo e arbóreo), pois, em função do estágio de degradação da área a ser recuperada, faz-se necessário a recomposição a partir de estratos inferiores (herbáceos).

Hoje, nos trabalhos de restauração ecológica, um dos assuntos mais debatidos é o relativo à diversidade de espécies. Então, estes estudos florísticos e fitossociológicos constituem a ferramenta mais precisa para obtermos informações importantes para constar no projeto de restauração sobre número e diversidade de espécies vegetais a serem utilizadas. Considerando que quanto maior a diversidade de espécies, teremos maior estabilidade do plantio, portanto um número maior de espécies utilizadas é desejável.

Como principais dificuldades nesta etapa, ressaltamos a falta de trabalhos referentes à composição florística e fitossociológica na maioria das regiões na área de floresta atlântica. Igualmente, para algumas regiões de domínio da floresta atlântica, é raro encontrarmos fragmentos que sirvam de referência, principalmente amostras de florestas primárias.

As informações, oriundas do estudo da estrutura da floresta, são de grande aplicabilidade. Por exemplo, a distribuição das espécies nos diferentes estratos da floresta, assim como sua presença/ ausência na regeneração natural podem dar indicativos da tolerância, comportamento e participação das espécies em outros estágios serais. O conhecimento das espécies ocorrentes, sua densidade, frequência, dominância, posição sociológica, regeneração natural, pode nos fornecer importantes subsídios para analisarmos este ecossistema em termos de sucessão florestal, interferindo na composição do plantio e espaçamento (distribuição de mudas), como também na definição de necessidades de intervenções intermediárias, envolvendo plantios de enriquecimento e manejo ambiental. 
Da mesma forma é conveniente, servindo como referência futura, o conhecimento de informações qualitativas sobre os fragmentos florestais vizinhos à área degradada, como: infestação de cipós, percentagem de árvores mortas, número de espécies raras e profundidade da camada de serapilheira.

\subsubsection{Reconhecimento da vegetação pioneira}

Uma estratégia, que pode ser usada, quando se tem limitação de tempo, ou de recursos, é a de se trabalhar com levantamentos de determinados grupos de espécies, que vão funcionar como bioindicadores. Levantamentos rápidos na área degradada, procurando observar espécies que surgem nas condições de degradação presente, e em áreas degradadas e abandonadas na vizinhança do local a ser recuperado, podem fornecer boas indicações. Estudos rápidos em áreas em estágio inicial de regeneração natural, em que temos grande concentração de espécies pioneiras, podem ser bons laboratórios para indicarem espécies ideais para as etapas iniciais da recuperação.

Consideramos o grupo das espécies pioneiras como sendo a chave para o processo de recuperação, pois estas espécies são responsáveis pelo arranque inicial, pelo rápido recobrimento do solo e pela criação das condições necessárias para as outras espécies se estabelecerem. Portanto uma boa escolha de espécies pioneiras, baseada nas observações regionais, é ponto básico para o sucesso de um projeto de recomposição.

\subsubsection{Banco de sementes e de plântulas}

A análise do potencial de regeneração da área degradada é fundamental para subsidiar os projetos de recuperação. Em alguns casos, o banco de sementes do solo é ativado com o desmatamento e possui a capacidade de recobrir a área degradada, sem nenhuma outra necessidade de intervenção, reduzindo custos de recuperação. Em casos drásticos, como queimadas, retirada das camadas superficiais do solo, aplicação de herbicidas, este banco de sementes é geralmente eliminado da superfície, dificultando a regeneração natural, fazendo-se necessárias intervenções, como o plantio de mudas.

O banco de plântulas, presente no sub-bosque de florestas, em estágios mais avançados de sucessão, é composto principalmente 
por espécies secundárias tardias e clímax, sendo geralmente eliminado com o desmatamento (corte raso). Em alguns casos, pode constituir um importante elemento para recuperação, por exemplo, em áreas onde foi realizado apenas o corte seletivo - extração de poucas árvores dentro de um fragmento florestal. Em áreas já desmatadas e abandonadas por um longo período de tempo, principalmente aquelas próximas a fragmentos florestais, pode se formar outro tipo de banco de plântulas, composto principalmente por espécies pioneiras e secundárias iniciais. Este banco de plântulas, por sua composição, pode ser responsável pelo rápido recobrimento e recomposição da área degradada.

Em muitas situações, onde temos um bom banco de sementes e de plântulas, o simples isolamento da área - contra fogo e animais domésticos - pode vir a dar bons resultados como método de recuperação. Estes meios de regeneração natural, quando presentes, podem reduzir em muito o custo da recuperação, mas é necessária uma correta avaliação do potencial biótico de regeneração da área. Infelizmente, na maioria das vezes temos áreas degradadas e abandonadas por muito tempo, das quais os bancos de sementes e de plântulas foram completamente eliminados do ambiente.

\subsubsection{Levantamentos faunísticos}

Considerando a importância dos animais como agentes polinizadores e dispersores de sementes, a relação existente entre flora e fauna, em florestas tropicais como a Atlântica, deve ser compreendida e considerada em trabalhos de restauração de um ecossistema degradado. Os levantamentos de fauna devem seguir o mesmo raciocínio espacial aplicado ao levantamento florístico, isto é, devemos ter uma perfeita caracterização da composição faunística de cada estágio sucessional, o que vai nos fornecer subsídios para futuros trabalhos de monitoramento - acompanhar a componente fauna na recuperação - e manejo de fauna (reintrodução, translocamento etc.). Considerando as limitações de tempo e de orçamento, uma boa alternativa são levantamentos rápidos e levantamentos de grupos bioindicadores de espécies ou grupos de espécies (como avifauna, formigas, roedores etc.). Existem experiências de uso de grupos bioindicadores em várias áreas de floresta atlântica, principalmente avifauna, mas, recentemente, estão sendo utilizados outros grupos faunísticos bioindicadores, mostrando bons resultados. 
Em regiões antes cobertas pela floresta atlântica, das quais não temos estas referências, devido ao processo de fragmentação, devemos nos basear nos estudos realizados nas áreas mais próximas existentes, de características similares, torna-se importante também, nestes casos, a realização de levantamentos históricos.

\subsection{Ambiente degradado - fatores limitantes}

Em regiões tropicais, possuímos, em geral, boas precipitações e temperaturas elevadas, portanto água e temperatura não são fatores limitantes nestas condições. Consideramos que as maiores limitações são resultantes da degradação dos solos - alteração das propriedades físicas, químicas e biológicas - e ausência de matéria orgânica. As limitações referentes à fertilidade dos solos podem ser consideradas as mais importantes em ambientes tropicais, sendo nitrogênio e fósforo os nutrientes que apresentam os níveis mais críticos.

Com referência aos níveis de fósforo, notamos que este nutriente é importante, principalmente, nas fases iniciais da implantação. No caso de métodos de recuperação, utilizando o plantio de mudas, o fósforo aplicado na cova, antes do plantio, tem mostrado resultados satisfatórios para o desenvolvimento das mudas, em especial, em relação ao crescimento inicial das mudas (aranque).

A degradação dos solos impossibilita a recuperação destas áreas, sendo necessária a intervenção antrópica para o reestabelecimento da vegetação e a reabilitação do ambiente. Considerando que, em geral, temos limitações de recursos, o ideal no processo de recuperação é a utilização de espécies que necessitem de uma pequena demanda de insumos e tratos culturais, reduzindo custos.

Áreas degradadas por mineração, onde os horizontes superficiais do solo foram removidos - justamente a porção do solo que contém a maior concentração de nutrientes, matéria orgânica e micro-organismos - nota-se grandes limitações no substrato, referentes à compactação dos solos e baixo teor de nutrientes. Em alguns casos específicos, temos também, nestas condições, problemas relativos à drenagem ácida e contaminação por metais pesados (principalmente áreas mineradas).

Em relação à disponibilidade de água, no domínio da floresta atlântica áreas de ocorrência da floresta estacional decidual e semidecidual, devemos nos preocupar com a definição correta da 
época do plantio. Estas áreas apresentam déficit hídrico em alguns meses do ano, podendo a água tornar-se fator limitante para o sucesso da recuperação.

\subsection{Diagnósticos no nível de paisagem}

No planejamento das ações de recuperação, principalmente em programas regionais de recuperação, que engloba grandes áreas, devemos considerar a dinâmica da paisagem, relacionando e se possível planejando a conexão de fragmentos florestais e a formação de uma rede de reservas interligadas. Neste momento, torna-se necessário um perfeito diagnóstico no nível de paisagem visando subsidiar nosso projeto de recuperação ambiental de áreas degradadas. A abordagem, no nível de paisagens, é importante visando inserir a área que estamos recuperando no contexto regional, adequando a realização de diagnósticos às diferentes escalas adequadas, conforme dimensão (tamanho) do programa de recuperação. O manejo de paisagem já é praticado há algum tempo em vários países da Europa, porém ainda é um campo de estudo que se inicia no Brasil. $\mathrm{O}$ enfoque atual do conceito compreende um aspecto mais amplo, holístico, abrangendo características biológicas, físicas e socioeconômicas de uma determinada região. Segundo o Programa Temático de Gestão Ambiental - PCNAT (1998), o manejo de paisagens envolve a conservação da biodiversidade, a conservação de solos e recursos hídricos, englobando também a dimensão humana (aspectos culturais, históricos, econômicos, sociais, éticos e espirituais).

No planejamento de paisagem está incorporado o conceito de ecologia de paisagem, definido por Forman e Godron (1986) como sendo o estudo da estrutura, função e mudanças em uma determinada área da terra heterogênea, composta por ecossistemas que interagem entre si. Portanto, a ecologia de paisagem envolve diversos campos de conhecimento como botânica e fitogeografia, ciências do solo, hidrologia, sociologia, economia, climatologia, enfim um grande número de ciências em interação.

O diagnóstico de paisagem geralmente se inicia em uma escala macro (em nível de paisagem), para posteriormente enfocar níveis mais pontuais e localizados (solo, vegetação, relevo, bacia hidrográfica, modelo de recuperação a ser adotado). É interessante utilizarmos o zoneamento em unidades de paisagem, estratificando os diferentes tipos de áreas degradadas presentes na região, classes 
de declividade, fragmentos florestais em diferentes estados de conservação (quantificando área, forma etc.) e tipo de solo, inserindo a área trabalhada neste contexto regional.

Nesta fase, vários aspectos ligados à paisagem devem ser considerados, como: área mínima (a ser recuperada, ou necessária em remanescentes do ecossistema original), forma futura da área a ser recuperada, proximidade de fragmentos florestais, possibilidades de interligações, forma da reserva a ser interligada, efeito de borda e diversidade das áreas vizinhas.

No estado atual de degradação da floresta atlântica, devemos sempre visualizar e projetar a formação de rede de reservas interligadas. A formação de redes de reservas interligadas permite a migração de animais entre reservas e fluxo de propágulos de plantas, esta conexão só é possível através das reservas de interligação de largura e comprimento planejados.

Em programas de grande escala, aplicação de conceitos de manejo de paisagem, é importante para definir e priorizar áreas a serem recuperadas em uma determinada região, assim como propor metodologias de recuperação ambiental de áreas degradadas e interligação de reservas a serem adotadas, reduzindo custos através

FOTO 8 - Exemplo de planejamento de paisagem, áreas alternadas com reservas de floresta atlântica e cultivos de Eucalipto, evitando-se grandes áreas contínuas de cultivos - Extremo sul da Bahia -Veracel Celulose S. A.

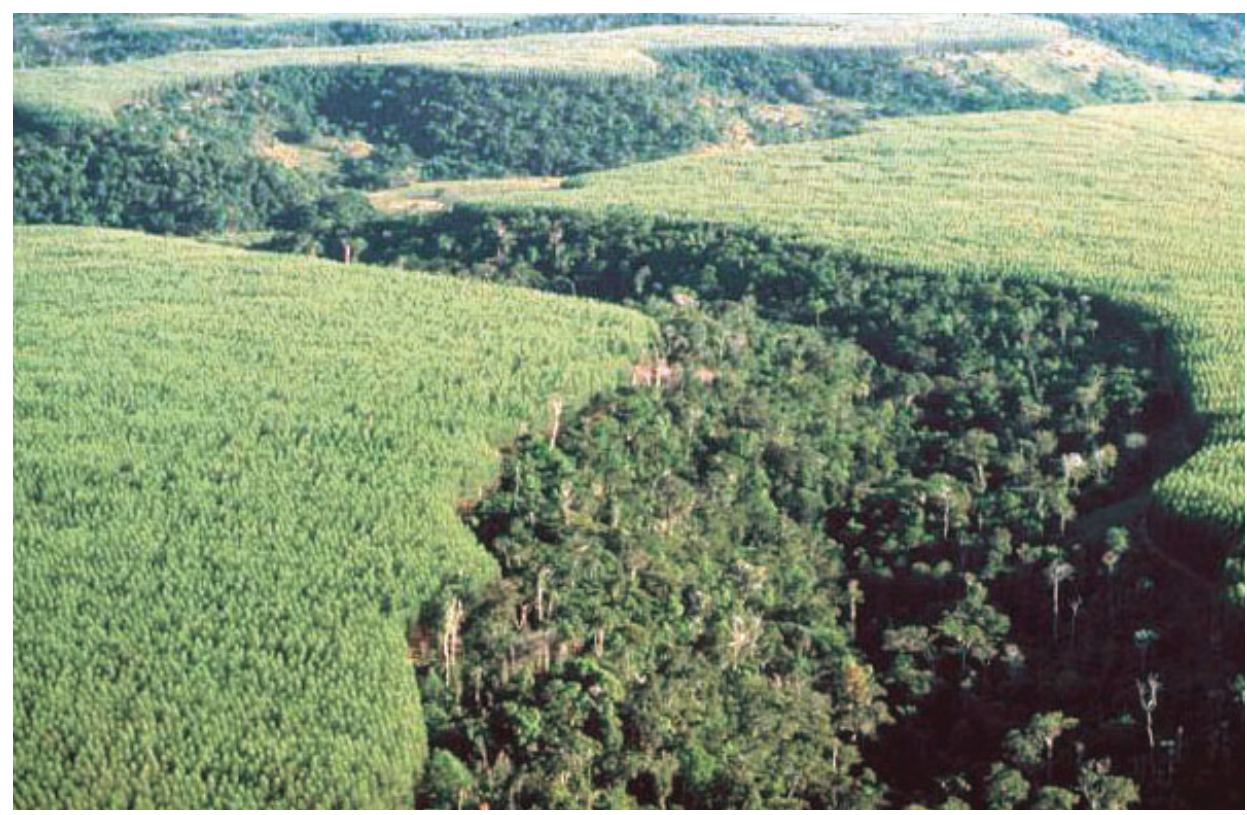


da utilização de um bom planejamento espacial. Para a eficiência deste planejamento é necessário uma boa base cartográfica da região, materiais como fotos aéreas, ortofotocartas, imagens de satélite e mapas detalhados são básicos nesta etapa.

O diagnóstico no nível de paisagem deve ser realizado em diferentes escalas. Partindo do conceito de manejo de paisagem, podemos considerar todas as bases de dados, associando-as às variáveis espaciais e através da utilização de um Sistema de Informações Geográficas, para melhor planejar todos os trabalhos de manejo e recuperação ambiental.

\subsubsection{Macrorregional}

No nível de macropaisagem, é diagnosticada toda região de influência direta e indireta da área trabalhada. Neste nível, são identificados os grandes fragmentos existentes na área global de trabalho (incluindo vizinhança). Assim, podemos ter uma visão geral sobre estado de conservação e possibilidades de interligação das mais importantes reservas (quando no caso de programas de recuperação, envolvendo grandes áreas). Neste nível são de grande importância os mapas temáticos como: a) vegetação (fisionomia, grandes fragmentos, vegetação secundária esparsa); b) clima; c) geomorfologia; d) hidrografia; f) solos e outros. Em programas de recuperação e interligação de reservas, grandes fragmentos são a unidade de planejamento no nível macro, a partir destes núcleos, estudamos as possibilidades de conexão de áreas florestais e maximização dos benefícios ambientais da recuperação.

As ações projetadas em nível de macropaisagem são conduzidas sempre no sentido de buscar parceiras e envolvimento de toda a comunidade da área considerada, não cabendo somente a União ou ao Estado ou a iniciativas individuais, deve ser um trabalho em conjunto, envolvendo toda comunidade regional.

\subsubsection{Regional}

$\mathrm{Na}$ análise no nível regional, são considerados os locais em que se localizarão as ações mais diretas do programa de recuperação, que se propõe implantar. Em uma escala menor, a região onde está inserida a área (pontual) que está sendo recuperada. Nesta escala, são levantados os fragmentos existentes na área abrangida em sua região 
de trabalho e vizinhança. Em grandes programas de recuperação, é, neste nível, que planejamos a melhor maneira de interligação de pequenos fragmentos com os maiores fragmentos (formação de rede de reservas interligadas), em função do grau de conectividade, tipo de vegetação e distância existente entre fragmentos. Nos diagnósticos no nível regional, são detalhados mapeamentos sobre aspectos físicos (topografia, solos e hidrografia), aspectos biológicos (flora e fauna) e aspectos antrópicos (levantamento social e econômico).

A principal ação no nível regional, principalmente, em programas mais globais, é a definição de áreas prioritárias para conservação da biodiversidade e recuperação (definir melhores caminhos de interligação).

\subsubsection{Local degradado}

Neste nível, os principais diagnósticos correspondem ao conhecimento da estrutura do meio físico. Compreendem um conjunto de ações mais pontuais, mas de suma importância para o sucesso do programa. Estes conhecimentos, combinados com as estratégias de recuperação biótica de ecossistemas, vão subsidiar então, jun-

FOTO 9 - Local degradado (Saibreira), no processo de recuperação a inserção da área degrada na paisagem circundante deve ser inclusa na etapa de planejamento da restauração

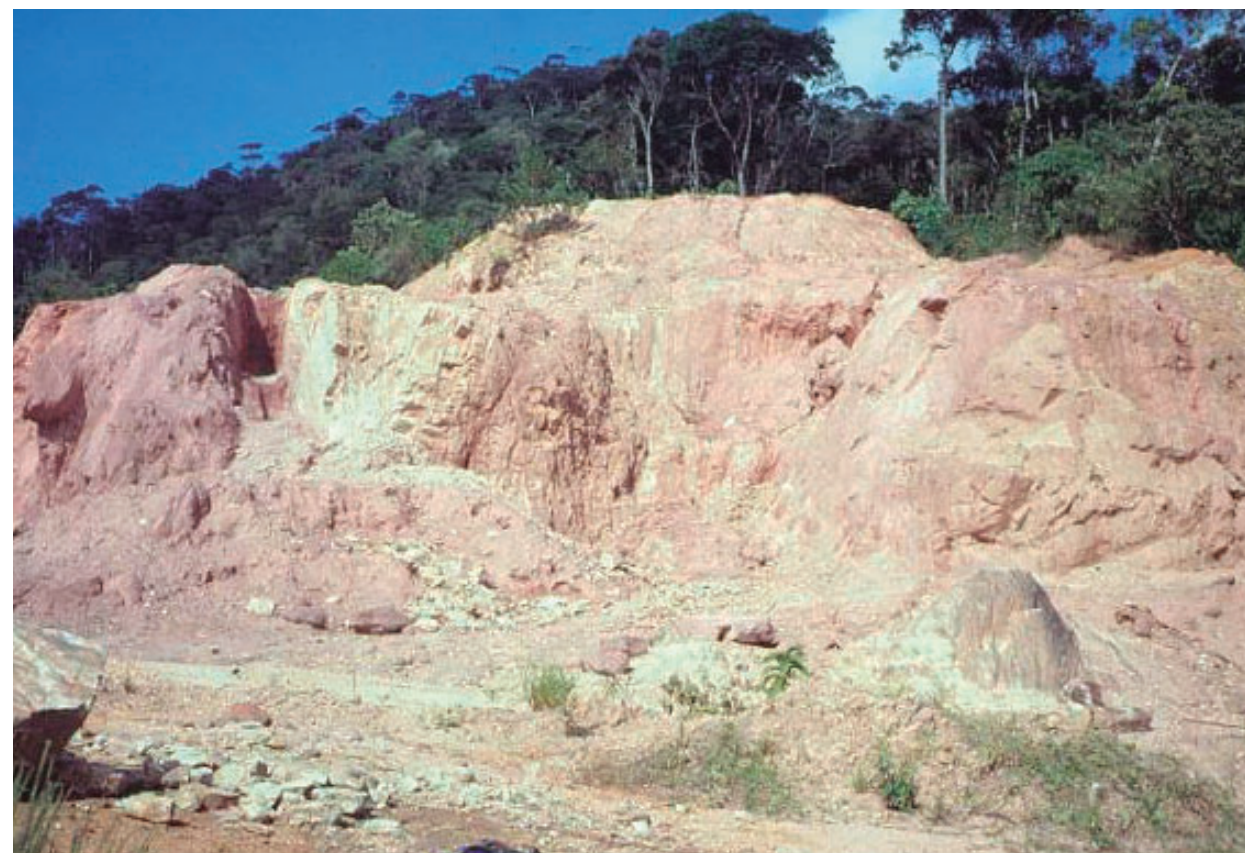


tamente com diagnósticos realizados em outros níveis de análise de paisagem, a elaboração do projeto técnico de recuperação. Aqui serão definidas as melhores estratégias a serem implementadas em cada situação de degradação presente, inserindo a recuperação no contexto regional. 


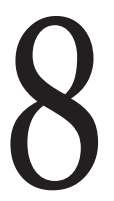

PONTOS BÁSICOS PARA DESENVOLVIMENTO DE PROJETOS DE RESTAURAÇÃO ECOLÓGICA 


\title{
8.1 Seleção de espécies
}

\begin{abstract}
diversidade de espécies utilizadas em projetos de restauração ecológica tem sido um dos pontos bem debatidos ulti1 mamente, torna-se muito importante termos embasamento científico para definição das espécies a serem utilizadas. Informações básicas, provenientes de estudos florísticos e fitossociológicos de ecossistemas e ambientes similares, são fundamentais para explorar e dar consistência a projetos de restauração ecológicos. Número mínimo de espécies a serem utilizadas já é exigido como podemos observar em legislação pertinente do estado de São Paulo, onde a Secretaria de Meio Ambiente, através da Resolução SMA 8, de 7-3-2007, determina que
\end{abstract}

\begin{abstract}
sempre será plantado um mínimo de 80 espécies nativas diferentes por hectare, respeitando critérios de divisão por classe de sucessão e condições específicas do local escolhido, visando restaurar a vegetação nativa da área ao mais próximo possível de sua condição original.
\end{abstract}

Também Martins (2012) relata esta questão da diversidade na restauração ecológica e afirma que

[...] fica evidente a importância do ecossistema de referência no planejamento da restauração ecológica. A restauração deve, portanto, ser planejada e avaliada com base na diversidade natural do tipo de ecossistema que se pretende restaurar.

Um dos pontos básicos para o sucesso do processo de recuperação de áreas degradadas é a correta seleção de espécies. A seleção de espécies é feita em função das condições climáticas, relevo, solos e biodiversidade local (GALVÃO; MEDEIROS, 2002).

Considerando o atual nível de conhecimento biológico de ecossistemas e sucessão, e a grande interação existente entre flora e fauna em áreas de floresta tropical, como a floresta atlântica, em recuperação ambiental, devemos somente utilizar espécies típicas dos ambientes específicos que estão sendo recuperados. Para isso é necessário um bom conhecimento do processo sucessional da região e da autoecologia das espécies a serem trabalhadas. O nível de detalhamento dos levantamentos de flora e fauna e o conhecimento das espécies vão variar em função da escala - tamanho da área que temos de reabilitar. 
Para a seleção de espécies a serem utilizadas em trabalhos de recuperação ambiental, podemos usar métodos diferenciados. A melhor maneira de aproximar da composição e da estrutura original do ecossistema degradado é realizar o processo de seleção de espécies, baseado no conhecimento detalhado da composição florística e fitossociológica de ambientes similares, ao que se deseja recuperar. Neste caso, além da composição e estrutura dos diferentes estágios sucessionais da vegetação (inicial, médio e avançado), visando conhecer e dominar o processo sucessional do ecossistema específico a ser recuperado. $\mathrm{O}$ conhecimento da flora e da estrutura de áreas de floresta primária (estágio clímax de sucessão) é referência básica do ponto onde queremos chegar (estrutura e composição final do trabalho de restauração).

Importantes referências para a seleção de espécies são obtidas em trabalhos de recuperação ambiental em regiões com condições similares àquelas que estamos trabalhando, como também observações do desenvolvimento de espécies em arboretos e plantios experimentais e observações em áreas degradadas em início de regeneração natural, vizinhas ao local que queremos recuperar.

A utilização de conceitos, como o de classificação de grupos ecofisiológicos de espécies (vide capítulo 5), facilita o entendimento do processo de sucessão e consequentemente a seleção de espécies. Dentre os grupos ecofisiológicos de espécies a serem utilizados, o grupo de espécies pioneiras se destaca principalmente para áreas mais degradadas. Quando nos referimos à utilização de espécies pioneiras, é importante não restringirmos a espécies pioneiras arbóreas, mas contemplarmos outros grupos de espécies como gramíneas e arbustivas, que conferem uma rápida proteção aos solos degradados, principalmente em áreas totalmente desprovidas de vegetação.

Com referência ao número de espécies a serem utilizadas, lembramos de que no processo natural a diversidade de espécies vai aumentando gradativamente, portanto, quando se conhece bem a sequência sucessional do ecossistema que está sendo recuperado, é possível utilizar um menor número de espécies na fase inicial (preferencialmente pioneiras e secundárias iniciais) e, posteriormente, enriquecer com espécies secundárias tardias e clímax, acelerando o processo natural de sucessão.

Vários autores citam critérios para seleção de espécies vegetais para fins de revegetação. A Secretaria do Meio Ambiente de São Paulo (1990) e Reis et al. (1999) relacionam uma série de critérios para seleção de espécies, ou seja: 
a. ocorrência natural na região;

b. ter caráter pioneiro, apresentando rápido crescimento, recobrindo rapidamente o solo e paralisando os processos erosivos;

c. alto potencial de dispersão da espécie;

d. rusticidade, apresentando bom desenvolvimento em solos com baixo teor de matéria orgânica e fertilidade;

e. produzir alimento para a fauna regional (zoocórica);

f. facilidade de propagação e obtenção de mudas;

g. apresentar grande densidade foliar;

h. apresentar grande potencial de reciclar nutrientes, fertilizando o solo e incorporando matéria orgânica neste substrato.

Portanto, na recuperação de áreas degradadas, necessitamos de espécies de crescimento rápido, que acelere o recobrimento do solo, com sistemas radiculares profundos que tragam nutrientes de camadas mais profundas do solo para a superfície, promovendo a ciclagem de nutrientes e acumulando matéria orgânica nas camadas superiores do solo (formação da manta orgânica), criando condições para o desenvolvimento de outras espécies. Do mesmo modo, é considerada como característica desejável, um bom formato de copa, com parte aérea bem desenvolvida lateralmente para proteção do solo.

\subsection{Inserção na paisagem, interação com vizinhança}

No início da arte de restauração de ecossistemas, a área destinada à restauração era vista de forma isolada e pontual, sem observar a paisagem circundante à área de intervenção. Com o desenvolvimento da área de Ecologia da Paisagem, iniciamos a aplicação destes conceitos no processo de restauração ecológica, de forma que a área destinada para restauração não é hoje mais vista de forma isolada, mas inserida no contexto da paisagem circundante e regional. A evolução da ciência de planejamento e ecologia da paisagem fornece hoje uma base teórica extremamente importante para a área de restauração, destes estudos originaram os planejamentos de corredores ecológicos, onde, a partir do estudo da paisagem, é definido o melhor "caminho" para interligação de dois fragmentos florestais isolados na paisagem. 
Quando consideramos os novos caminhos da restauração ecológica, e não somente de uma recuperação florestal, mas de uma restauração do ecossistema e ambiente natural, a interligação de áreas isoladas, em que temos populações de flora e fauna isoladas, esta busca da conectividade de fragmentos permite o aumento do fluxo gênico e intercâmbio entre as populações vegetais e animais destes fragmentos florestais isolados. Em função do tamanho e estado de conservação dos fragmentos, a serem interligados, este planejamento de implantação de corredores, interligação de áreas florestais remanescentes, pode ter um grande retorno na restauração destes ambientes.

Em áreas de floresta atlântica, nas quais temos grande fragmentação de habitats, a visão da paisagem torna-se fundamental para o planejamento espacial da restauração ecológica, as estratégias de restauração passam não somente por boas técnicas de plantio, com espécies bem selecionadas e adequadas aos diferentes ambientes, mas também pela visão espacial, onde a área, objeto da restauração, possa se inserir e se conectar na paisagem por fragmentos florestais vizinhos ou adoção da técnica de ampliação ecológica.

\subsection{Princípios da Sucessão Ecológica}

Conforme mencionado anteriormente, o grande aprendizado na área de restauração ecológica nos é dado pela mãe natureza. As observações dos princípios de sucessão são fundamentais para acelerarmos o processo sucessório vegetal e a restauração da área degradada. Hoje, este conceito e a aplicação destes princípios da sucessão ecológica são básicos para restaurar ecossistemas tropicais como a floresta atlântica. A boa observação de campo, anotando as espécies pioneiras presentes na área que se pretende restaurar, assim como a realização de estudos florísticos e fitossociológicos para melhor conhecimento da Sucessão Ecológica, é fundamental para subsidiar o planejamento e o projeto de restauração ecológica.

\subsection{Métodos biológicos de recuperação de áreas degradadas}

A utilização de métodos biológicos na recuperação de áreas degradadas constitui a maneira mais econômica e eficiente de 
recuperação destas áreas. Métodos mecânicos e obras civis representam custos elevados e nem sempre são alternativas eficientes para recuperação de áreas. Neste capítulo, procuramos discutir os métodos biológicos mais utilizados na recuperação de áreas degradadas. Estas técnicas estão sofrendo grandes avanços ultimamente e têm evoluído dia a dia em suas aplicações. Nas últimas décadas, tem crescido o interesse por recuperação de áreas degradadas, e este interesse tem colaborado para o aprimoramento de técnicas visando melhorar e acelerar este processo.

No próximo capítulo, citamos algumas das principais técnicas utilizadas atualmente, enfocando principalmente aspectos práticos, visando facilitar a operacionalidade de implantação. Muitos dos métodos mencionados, nesta parte, podem e devem ser combinados entre si, visando maximizar os benefícios e acelerar ao máximo o processo de recuperação. 



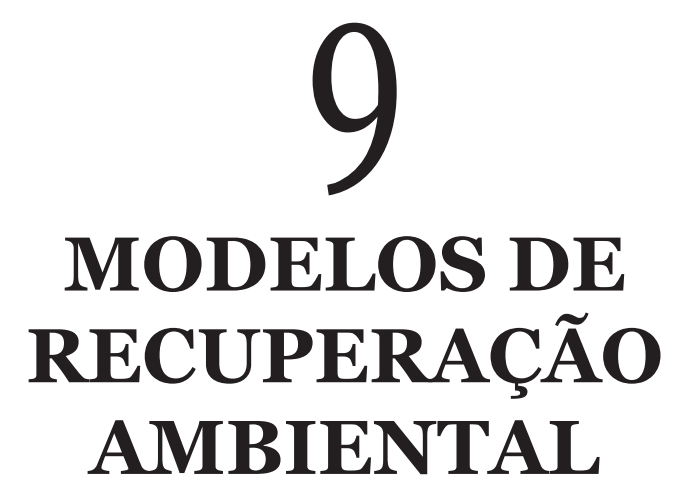



Q uando pensamos em recuperar ambientalmente uma área, devemos sempre associar nosso planejamento aos processos naturais de sucessão, além de considerar sempre as interferencias externas presentes nos ecossistemas que fazem com que as sequências sucessionais possam tomar diferentes caminhos. $\mathrm{Na}$ verdade, reproduzimos o processo natural, e se temos bom conhecimento deste, vamos acelerar as mudanças das comunidades visando atingir o clímax, mesmo que este originalmente não seja alcançado. Entende-se, hoje, por recuperação ambiental, um termo mais amplo, mais holístico, que envolve recuperação do meio biótico e do meio físico. Conforme citado por Reis et al. (1999), devemos promover a sucessão de todos os elementos (solo, microflora, flora e fauna), o que fará que a área ganhe nova resiliência (capacidade de voltar a um estado de equilíbrio).

\subsection{Alguns modelos de recuperação ambiental}

Para o planejamento e desenho de projetos de recuperação ambiental de áreas degradadas, é necessário pensar globalmente em termos do ecossistema a ser recuperado, sua estrutura atual e necessidade de reestruturação física (baseado nos conhecimentos obtidos nos diagnósticos) e conhecimento da sucessão, visando acelerar a recomposição de vegetação natural da área. Temos sempre de ter em mente nosso principal objetivo, isto é, recuperar a floresta o mais próximo possível da original, o que obteremos somente através do conhecimento dos vários compartimentos e suas inter e intrarrelações. Assim, poderemos compreender os processos sucessionais, permitindo-nos traçar estratégias de recuperação eficazes que, realmente, acelerem a reabilitação de áreas degradadas.

Hoje em dia, com o conhecimento existente sobre ecossistemas naturais, como no caso da Mata Atlântica, consideramos que não é admissível o uso de espécies exóticas (de regiões, ecossistemas / ambientes diferentes daquelas que estão sendo recuperadas) em plantios de recuperação ambiental. Mesmo em plantios homogêneos necessários para áreas com nível maior de degradação, pode ser utilizada a técnica de plantios mais homogêneos com espécies pioneiras regionais que possuem ótima relação com a fauna silvestre, atraindo este componente rapidamente para a área em recuperação. 
Observa-se, no Brasil, uma tendência à elaboração de "receitas" generalizadas, este procedimento generalista é, muitas vezes, a causa do fracasso de muitos projetos de recuperação ambiental. O tratamento de reestruturação física da área e a seleção das espécies adequadas a seu ambiente específico, densidade de plantio ou semeio (baseados em levantamentos florísticos e estruturais), tipo de propágulo (semente, estacas ou mudas), cronograma de implantação, enfim todo projeto deve ser desenvolvido voltado, especificamente, para a área em questão.

No caso de desenvolvimento de modelos para florestas tropicais, como a floresta atlântica que estamos trabalhando, a base de conhecimento sobre a biodiversidade é fundamental para o desenvolvimento de modelos de manejo e recuperação, de preferência quando nosso objetivo é recompor a biodiversidade original da região. Frisamos a necessidade do planejador de possuir uma visão holística, indispensável, considerando que estamos trabalhando com um ecossistema complexo, como a floresta atlântica, que possui muitas interações entre os elementos bióticos e abióticos.

O desenho de modelos de recuperação de áreas degradadas deve contemplar e se adequar a cada situação de degradação presente na área. Com base em informações obtidas no diagnóstico (meio físico, biótico, presença de regeneração natural, proximidade de fragmentos florestais e fatores limitantes) e informações sobre sucessão natural do ecossistema em questão, é definido o melhor método ou combinação de métodos específicos a serem utilizados para cada situação, ou conjunto de situações apresentado. Geralmente, quanto mais degradada se apresenta uma área, devemos utilizar uma maior densidade de espécies pioneiras, nunca esquecendo que espécies pioneiras são sempre especialistas em determinados ambientes, apesar de possuírem grande plasticidade em determinados ambientes, apenas algumas espécies pioneiras devem ser utilizadas (exemplo: matas ciliares, brejos, topo de morros).

A definição do modelo de restauração para uma determinada área degradada depende de fatores como: grau de degradação e histórico da área, disponibilidade de sementes e mudas, solo, clima, máquinas e implementos agrícolas e recursos financeiros disponíveis (FERRETTI, 2002).

A seguir, seguem dicas gerais para escolha e desenho de modelos de recuperação ambiental: 
1. O Diagnóstico da área a ser recuperada e entorno deve ser a principal referência para definição das estratégias de recuperação a serem utilizadas. Estudos florísticos e fitossociológicos de remanescentes florestais presentes, em áreas próximas ou vizinhas à área a ser recuperada, são as melhores referências para definição de espécies a serem utilizadas, espaçamento de plantio, proporções entre grupos ecológicos etc.

2. Utilizar somente espécies nativas da região, tomando como base estudos florísticos e fitossociológicos, realizados nas proximidades da área em ambientes similares (encostas, matas ciliares, áreas planas, brejos etc.).

3. É fundamental a utilização de espécies pioneiras, principalmente, se a área se encontrar totalmente sem vegetação. A proporção de espécies pioneiras deve ser definida em função do grau de degradação da área a ser recuperada.

4. A experiência prática tem mostrado que, quanto maior diversidade de espécies nativas utilizarmos na fase inicial dos plantios, melhores serão os resultados em longo prazo. Portanto devemos utilizar o maior número possível de espécies, sempre tomando como base os estudos florísticos e fitossociológicos realizados.

5. Em florestas tropicais geralmente mais de $80 \%$ das espécies têm suas sementes dispersas por animais. Portanto devemos verificar na listagem de espécies que iremos utilizar a proporção de espécies zoocóricas presentes. Devemos lembrar de que médios e grandes mamíferos têm seus alimentos geralmente em espécies secundárias tardias e clímax, e pequenas aves e morcegos têm seus alimentos, em especial, produzidos por espécies pioneiras.

Dentro dos objetivos da recuperação apresentamos, a seguir, alguns modelos/estratégias de recuperação, baseados nos conceitos de restauração ecológica, que podem ser utilizados em diferentes situações apresentadas. Em muitas áreas, a melhor estratégia pode ser uma combinação do uso de vários modelos de recuperação. 


\subsubsection{Condução da regeneração natural}

Em função do potencial de regeneração apresentado por uma área, este é um método que pode ser eficaz e se tornar uma boa estratégia a ser utilizada, em áreas com menor grau de perturbação, onde temos uma boa cobertura florestal e possibilidade de migração de propágulos, principalmente em função do custo de implantação. A estratégia de contemplar a regeneração natural consiste em favorecer a recuperação natural de uma área após distúrbio, funciona bem para áreas recém-desmatadas e que possuem meios de regeneração natural, ou seja, banco de sementes, banco de plântulas, chuva de sementes e rebrota de cepas.

Em casos de áreas desmatadas há mais tempo, é interessante uma análise mais minuciosa da regeneração. A proximidade da área degradada de fragmentos florestais pode também acelerar a regeneração natural através da migração de propágulos (atuação do processo denominado de chuvas de sementes).

O uso deste modelo pode estar combinado à adoção de algumas medidas complementares como o cercamento da área (necessário para evitar a entrada de animais domésticos), controle de espécies invasoras (espécies como gramíneas, ciperáceas e outras invasoras podem inviabilizar o sucesso deste método), coroamento das mudas presentes (limpeza ao redor das mudas arbóreas presentes), construção de aceiros (necessário para evitar que o fogo, proveniente de áreas vizinhas, avance sobre a área), colocação de poleiros artificiais (boa prática, pois pássaros, ao pousarem para descansar, trazem sementes de áreas vizinhas - ficam presas ao bico ou através das fezes), plantio de mudas arbóreas nas clareiras (se a área apresentar boa regeneração de uma maneira geral, porém com algumas áreas internas - clareiras - sem regeneração), o plantio de espécies pioneiras nas áreas de clareiras pode uniformizar mais a regeneração da área em questão.

A rebrota de cepas pode representar, em alguns casos, a forma mais importante de regeneração da vegetação florestal, o potencial de rebrota de espécies florestais e arbustivas destas áreas, especialmente em áreas que sofreram de queimadas, tem grande importância na regeneração e recobrimento da área perturbada. Em florestas tropicais, várias espécies se destacam pelo potencial de rebrota de cepas, regenerando bem após certos distúrbios. 
Este método de recuperação ambiental apresenta menor custo de implantação em relação a outros e, com ajustes, pode apresentar bons resultados.

\subsubsection{Plantio de mudas}

Dentre os métodos de recuperação de áreas degradadas, o plantio de mudas é o mais usual. O objetivo principal é acelerar o processo de sucessão natural, proteger rapidamente o solo contra a erosão e garantir o aceleramento e sucesso da recuperação. Nas áreas de domínio da floresta atlântica, em que temos geralmente boas condições climáticas (boas precipitações e chuvas bem distribuídas) é um método muito indicado, por isso um dos mais utilizados. A grande vantagem deste método é termos o controle da densidade de plantio, que deverá ser preferencialmente próxima da original - no mesmo ambiente e estágio sucessional, como também controle da composição florística inicial, que, se baseada em estudos técnicos florísticos e fitossociológicos, vai ter composição próxima da floresta existente naquele ecossistema e ambiente específico. Este método de recuperação é de fácil operacionalização e de custo reduzido em áreas de fácil acesso. Conforme a situação, fase de degradação e

FOTO 10 - Muda plantada de gurindiba (Trema micranta Triana), município de Eunápolis - estado da Bahia

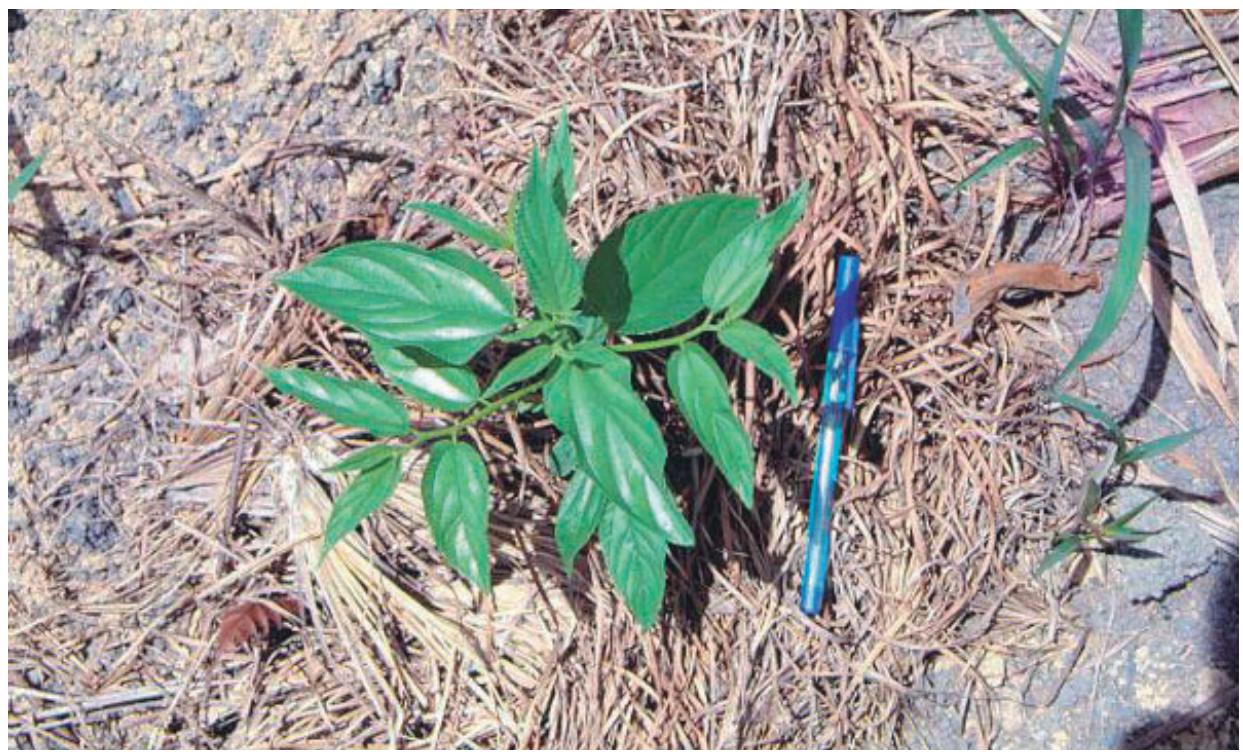


perturbação da área degradada, o plantio de mudas pode contemplar espécies herbáceas, arbustivas ou arbóreas, visando fornecer uma cobertura imediata e proteger melhor o solo.

Este método também é utilizado para os chamados plantios de enriquecimento, onde vamos introduzir espécies dos grupos secundárias tardias e clímax em áreas nas quais já existe alguma regeneração florestal e, consequentemente, condições para o desenvolvimento de espécies destes grupos - principalmente sombra e solo florestal já em formação.

Quando não temos um viveiro florestal próximo à área a ser restaurada, uma alternativa a ser considerada é o plantio de mudas coletadas no campo, em áreas vizinhas ou ambientes similares. Além da economia da produção da muda, ganhamos tempo (para formação das mudas). Esta técnica pode dar resultados satisfatórios em função das espécies a serem trabalhadas. Várias espécies arbóreas podem ser plantadas com a utilização deste método, porém é necessário considerar o impacto na regeneração natural das áreas de origem (retirada) das mudas, assim como ter cuidados para não danificar o sistema radicular na operação de transplante. Este método somente deve ser utilizado onde temos extrema dificuldade de obter material de propagação (sementes e mudas), sendo aplicado principalmente em plantios de enriquecimento, em ambientes sombrios. No caso de áreas abertas, as mudas teriam de passar por um período de aclimatação, antes de serem levadas para o plantio no campo. Silva Filho (1988) cita que algumas espécies apresentam grandes produções de sementes e abundante regeneração natural, este excesso de mudas produzidas pode ser utilizado em outras áreas, pobres em materiais de propagação. A grande vantagem do transplante é a redução do custo de produção das mudas e adaptação às condições mesológicas da região. Este método deve ser sempre aplicado, quando o solo estiver úmido, de preferência na estação chuvosa da região.

A recuperação de matas ciliares, hoje bastante com ênfase em função do pagamento de serviços ambientais, especialmente na "produção de água", tem sido realizada principalmente através do plantio de mudas nativas autóctones do ambiente de florestas ripárias (matas ciliares). A realização prévia de estudos florísticos e fitossociológicos, em fragmentos florestais de matas ciliares na mesma bacia, no lugar em que se pretende conduzir os trabalhos de 
FOTO 11 - Plantio de mudas na recuperação de matas ciliares, restauração das matas ciliares do Rio da Dona, Santo Antônio de Jesus, Bahia

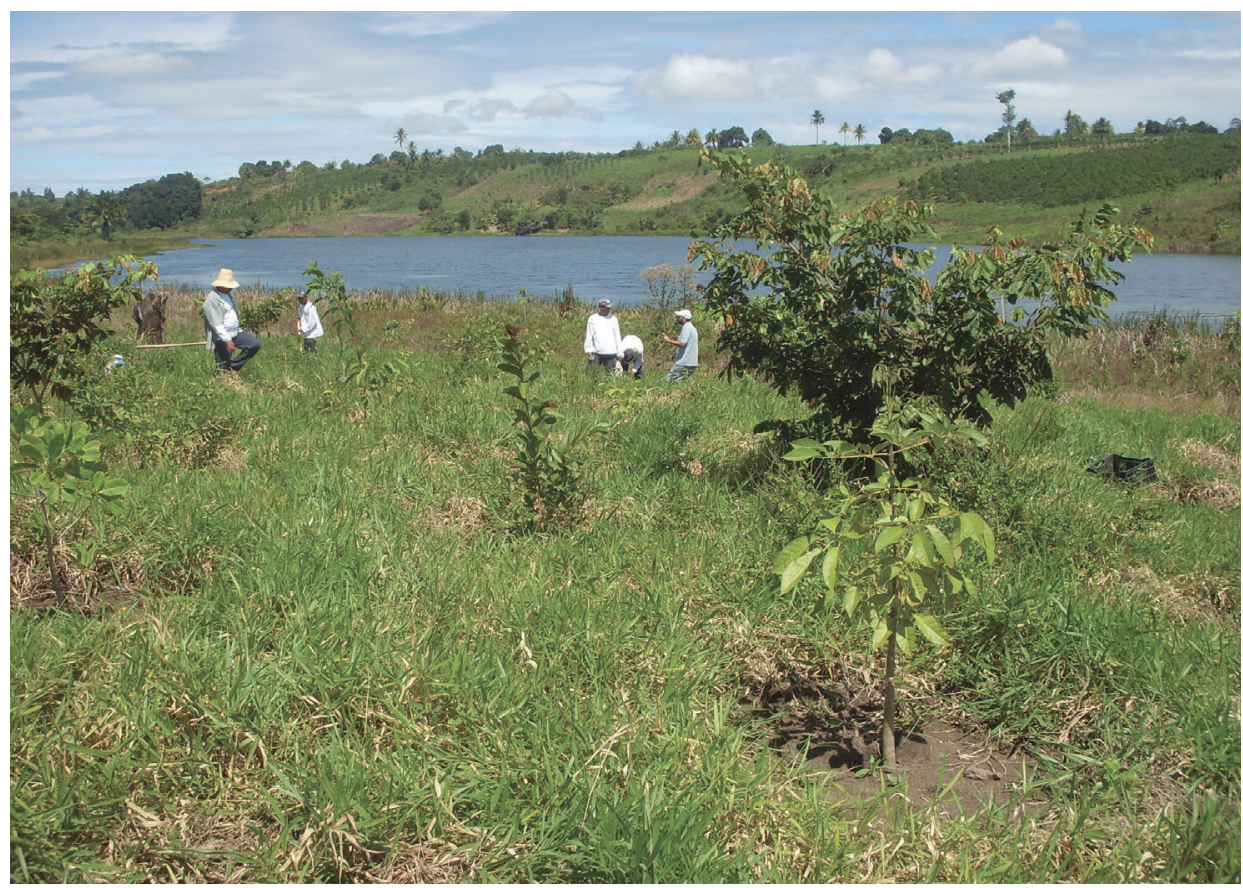

restauração ecológica é um requisito básico quando se pretende restaurar a floresta mais próxima possível da original. A foto 11 mostra trabalho de restauração das matas ciliares, realizado no município de Santo Antônio de Jesus, no lago da barragem do Rio da Dona, responsável pelo abastecimento de água da cidade.

\subsubsection{Recuperação com espécies pioneiras}

O plantio de recuperação ambiental com o uso de 100\% de espécies pioneiras é um bom modelo para ser aplicado em algumas situações específicas, de preferência em áreas vizinhas ou bem próximas a algum fragmento florestal, onde provavelmente os ajustes naturais sejam suficientes para promover o enriquecimento natural da área, reduzindo custos de plantios de enriquecimento complementares. É recomendada, também, quando a área se apresenta muito degradada de tal forma que a regeneração natural não acontece, e espécies secundárias e clímax não se estabeleceriam neste ambiente (ambientes de baixa resiliência). Este modelo tem como 
vantagem o recobrimento de vegetação rápido do local em restauração, proporcionando rápida proteção ao solo. Com relação aos custos, apresenta menor custo de manutenção, pois, devido ao rápido crescimento das espécies e sombreamento, a vegetação competidora sai logo do sistema, porém pode ter custos adicionais se forem previstos e necessários plantios de enriquecimento em longo prazo.

A utilização de espécies florestais de rápido crescimento, principalmente as pioneiras, é mencionada por vários autores, que citam este método como aquele que permite uma melhor aproximação das condições existentes do ecossistema original (para áreas antes cobertas por florestas, como a Atlântica, por exemplo). Uma grande vantagem da utilização de espécies pioneiras é sua rusticidade, proporcionando redução de gastos nas etapas de implantação e manutenção, devido ao rápido recobrimento do solo.

Para ilustrar, damos um exemplo - descrição superficial de um modelo de reabilitação (com uso de espécies pioneiras), que pode ser aplicado em áreas degradadas, utilizando somente espécies pioneiras autóctones com a finalidade de obter rápido recobrimento do solo e acelerar o processo de sucessão natural. Possibilita enriquecimentos futuros - via sementes ou mudas - de espécies pertencentes a outros grupos ecológicos, após a área desenvolver ambientes propícios para o enriquecimento.

Este modelo pode ser conciliado com outros métodos e técnicas como o "ilhas de biodiversidade", "uso de serapilheira", "ampliação ecológica", visando garantir sua sustentabilidade das restaurações da área em longo prazo.

\subsubsection{Formação de ilhas de diversidade (Nucleação)}

Este modelo de restauração, que pode ser utilizado, é baseado em diversos estudos sobre recuperação de áreas degradadas, mostrando que a tendência natural do processo sucessional é não recobrir áreas de maneira uniforme (GRIFFITH et al., 1994), a natureza utiliza "ilhas de diversidade". Estas áreas de disseminação de propágulos são responsáveis pelo aumento de diversidade de uma área em processo de recuperação. Este processo natural pode ser replicado em modelos de recuperação, com formação de ilhas de vegetação com espécies chaves para atração de fauna (polinizadores e dispersores). 
Autores, como Reis et al. (1999), citam os chamados "centros de alta diversidade", áreas onde deveriam ser incluídas as formas de vida das espécies vegetais e suas adaptações aos estágios sucessionais (pioneiras, oportunistas, climácicas, ervas, arbustos, árvores, lianas e epífitas), além de considerar as adaptações aos processos de polinização e dispersão (anemocórica, zoocórica e outros) e de fenofases (principalmente floração e frutificação). No planejamento destas "ilhas de diversidade", áreas são onde intervimos de maneira mais intensa no processo de recuperação, é importante considerarmos também aspectos fitossociológicos (densidades de plantio previamente planejado), baseados em estudos fitossociológicos e de localização (devem ser localizadas estrategicamente no núcleo ou parte central da área, ou na parte mais elevada da área que está sendo recuperada, visando destacar a eficiência na dispersão de propágulos e enriquecimento da diversidade das áreas vizinhas).

Apesar de ser um modelo de recuperação de baixo custo, a recuperação ambiental, a partir de ilhas de vegetação, tende a ser um processo lento, variando em função do número e tamanho das ilhas, sendo recomendada a utilização de espécies atrativas da fauna silvestre (MARTINS, 2001).

O modelo misto entre ilhas (com espécies não pioneiras) e plantio de espécies pioneiras, na área total, também pode ser uma boa estratégia, conforme citado por Kageyama e Gandara (2000). Esta estratégia vai promover o rápido recobrimento do solo, diminuindo o processo de erosão do solo, porém a diversidade de espécies iniciais do plantio é baixa. Autores, como Galvão e Medeiros (2002), recomendam que este modelo seja utilizado para áreas de no mínimo 20 hectares e, neste caso, tenhamos um núcleo de no mínimo 4 hectares. Segundo estes autores, a grande vantagem deste modelo é redução de custos.

Entre as estratégias de nucleação que podem ser utilizadas, segundo Martins (2012), podemos destacar a transposição da serapilheira, do banco de sementes, galhadas, manejo da regeneração natural, resgate de plântulas e a semeadura direta com alta diversidade.

\subsubsection{Modelo sucessional - plantio em linhas alternadas}

O plantio em linhas alternadas é uma boa solução para facilitar o lado operacional de implantação, por isso é o modelo mais 
comumente aplicado em grandes áreas, principalmente em plantios mecanizados. As linhas alternadas facilitam todo trabalho de preparação e embalagem das mudas no viveiro florestal, assim como a parte operacional de plantio de campo, onde os trabalhadores facilmente entenderão o procedimento de plantio. Algumas empresas se utilizam de caixas marcadas ou de diferentes colorações para diferenciar as caixas com espécies pioneiras e de outros grupos. Normalmente, planta-se uma linha de espécies pioneiras (deverão ser utilizadas, nesta linha, todas pioneiras específicas para o ambiente que estamos trabalhando), e outra linha com espécies não pioneiras (representando 50\% das mudas plantadas) (FIGURA 2). Este tipo de plantio facilita bem os aspectos operacionais de implantação do plantio de restauração, separando caixas/contentores de mudas pioneiras e de outros grupos de diversidade.

FIGURA 2 - Esquema de modelo de linhas alternadas, onde " $X$ " representa espécies pioneiras e "O" representa espécies secundárias iniciais, tardias e clímax

\begin{tabular}{|ccccccccccccc|}
$x$ & & $x$ & & $x$ & & $x$ & & $x$ & & $x$ & \\
$x$ & 0 & & 0 & & 0 & & 0 & & 0 & & 0 \\
$x$ & 0 & $x$ & 0 & $x$ & & $x$ & & $x$ & & $x$ & \\
$x$ & & $x$ & & $x$ & & $x$ & & $x$ & & $x$ & \\
\hline
\end{tabular}

Neste modelo de utilização de linhas alternadas, outro item, que deve ser incorporado na seleção de espécies, é a classificação com base na forma da copa, assim devemos utilizar nas linhas destinadas ao plantio de espécies pioneiras, sempre com espécies pioneiras possuidoras de copa larga, pois esta estratégia vai proporcionar o fechamento mais rápido do dossel que está sendo formado na restauração ecológica e, consequentemente, formar sombra e, como resultado, eliminar mais rapidamente a vegetação competidora rasteira (em especial gramíneas) que existia na área a ser restaurada. Esta medida tem importância também na redução do custo financeiro da restauração ecológica, pois as plantas, normalmente competidoras, vão desaparecer mais rápido do ecossistema que ganha mais rapidamente forma e característica florestal. A FIGURA 3 mostra outra alternativa de modelo com uso de maior densidade de espécies pioneiras $(75 \%$ 
FIGURA 3 - Esquema de modelo de linhas alternadas, onde " $X$ " representa espécies pioneiras, que neste modelo representam $75 \%$ das espécies utilizadas e "O" representa espécies secundárias iniciais, tardias e clímax ( $25 \%$ das espécies utilizadas)

\begin{tabular}{|lllllllllllllll}
\hline & & $x$ & & $x$ & & $x$ & & $x$ & & $x$ & \\
$x$ & & & $x$ & & $x$ & & $x$ & & $x$ & & $x$ & \\
& $x$ & & 0 & & $x$ & & 0 & & $x$ & & 0 \\
& & & & & & & & & & & & & &
\end{tabular}

das espécies plantadas) contra 25\% de espécies de outros grupos que vão conferir diversidade ao plantio realizado (secundárias iniciais, tardias e clímax).

Para a aplicação de fatores relacionados à forma e crescimento horizontal da copa, no modelo de linhas alternadas com $75 \%$ de espécies pioneiras, a classificação com base na forma da copa também tem grande aplicabilidade. Nas linhas, onde existem somente os "X" (linhas de 100\% pioneiras), devemos utilizar sempre espécies pioneiras de copa larga, facilitando o fechamento mais rápido do dossel e a redução do custo de manutenção.

Do ponto de vista operacional, neste modelo, podemos utilizar diferentes tipos de tubetes ou embalagens, ou mesmo caixas demarcadas, para diferenciar, na prática, as espécies pioneiras e não pioneiras. Funcionalmente, uma estratégia muito utilizada é das mudas virem do viveiro já preparadas e misturadas em caixas de plantio, ou caixas somente de pioneiras, ou caixas já misturadas pioneiras, e outros grupos nas proporções previstas no modelo a ser utilizado, esta prática facilita muito a operação de plantio de mudas no campo. As espécies a serem utilizadas e as respectivas quantidades de mudas de cada espécie deverão ser definidas em função dos estudos florísticos e fitossociológicos, realizados para o local em recuperação.

Este modelo se mostra bem prático e flexível, pois permite a combinação de espécies pioneiras e não pioneiras em diferentes proporções. Por exemplo, em uma área mais degradada, podemos utilizar 75\% de espécies pioneiras, isto é, uma linha de espécies pioneiras e outra linha, alternando espécies pioneiras e não pioneiras (FIGURA 2).

O espaçamento a ser utilizado vai variar em função dos estudos fitossociológicos, realizados na região (áreas ainda com cobertura 
florestal que possuam características similares a área a ser recuperada), assim como o tipo e exposição do solo, declividade (relevo), presença de plantas invasoras e disponibilidade de recursos financeiros e de equipamentos (maquinários).

Para melhor desempenho deste modelo sugerimos que os plantios não sejam muito alinhados como reflorestamentos comerciais. Eles devem seguir somente uma linha de referência sem compasso exato de espaçamento, dentro da mesma "linha", da mesma maneira podemos desalinhar as covas, buscando maior semelhança com a regeneração natural e com o que observamos nas florestas nativas.

O plantio, em uma só etapa, pode reduzir em muito o custo da recuperação. É um método indicado para áreas que apresentam

FOTO 12 - Sequência de recuperação ambiental de uma área por plantio de mudas em linhas alternadas, onde primeira foto com seis meses após plantio, segunda com 5 anos após plantio e terceira foto 10 anos após plantio, quando a altura médio ultrapassou 10 metros. Santa Cruz Cabrália, Bahia
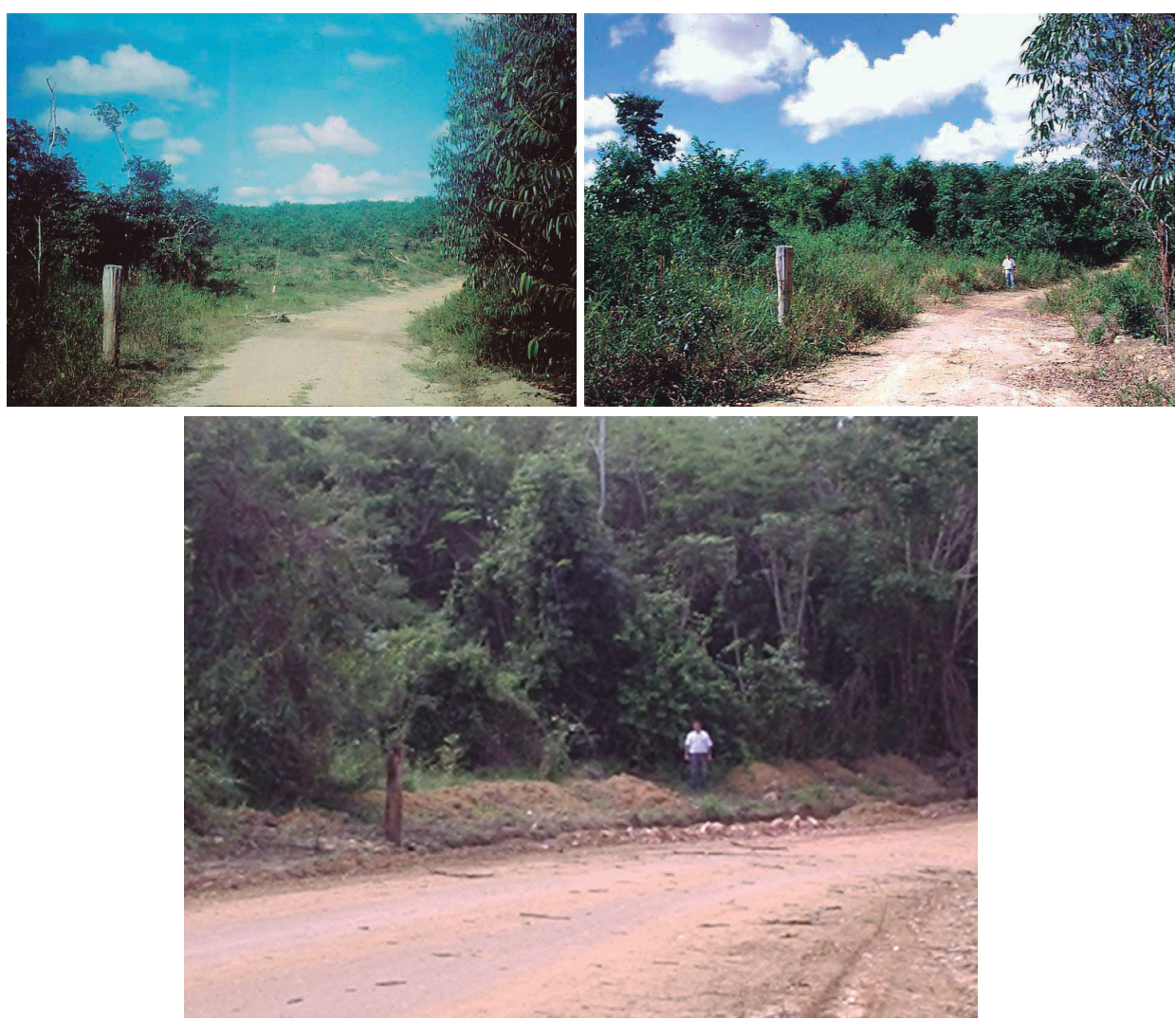
condições favoráveis para um rápido desenvolvimento das mudas e estabilização e sustentabilidade do plantio.

A implantação destes modelos no campo, considerando as experiências do extremo sul da Bahia (ALMEIDA, 1994), tem demonstrado que, nos plantios, em linhas alternadas, realizados em áreas abertas, a mortalidade tem sido bem maior no grupo de espécies não pioneiras que na linha de espécies pioneiras. Portanto este modelo tem esta grande vantagem de poder adequar, conforme estado de degradação apresentado na área, a exata proporção de espécies pioneiras e não pioneiras.

\subsubsection{Modelo sucessional - plantios em módulos}

O modelo sucessional separa as espécies por grupos ecofisiológicos. Neste modelo de módulos, utiliza-se uma planta na parte central (secundária tardia ou clímax), rodeada por quatro espécies pioneiras (espécies sombreadoras). Os módulos são implantados dispostos por toda área que está sendo recuperada. É um modelo mais aplicável em áreas menores, para áreas maiores é mais comumente utilizado o plantio em linhas alternadas.

\subsubsection{Indução da chuva de sementes}

É um método de custo reduzido que é aplicável em áreas de difícil acesso, onde a aplicação de outros métodos de recuperação seria inviável operacionalmente, em função de transporte de insumos, pessoal etc. Este método é mais aplicado quando temos boa disponibilidade de sementes na região de implantação do projeto e, normalmente, existe algum impedimento ao plantio de mudas.

Pesquisas realizadas, utilizando este método, no estado de São Paulo (ENGEL et al., 2002), mostram que a semeadura direta pode ser viável, principalmente para algumas espécies pioneiras e quando se faz um tratamento prévio na superfície do terreno.

\subsubsection{Plantio inicial de mudas e posterior semeio}

Modelo misto que constitui o plantio inicial de $100 \%$ de espécies pioneiras na área total e, posteriormente (após o plantio gerar condições de sombra e solo para germinação de espécies secundárias), 
a promoção do enriquecimento da área com sementes de espécies secundárias tardias e clímax entre o plantio de espécies pioneiras. As sementes de espécies secundárias tardias e clímax que, geralmente, são sementes grandes e não possuem problemas de dormência, germinando bem nas condições de campo. É um método de baixo custo (pois implica somente no plantio de pioneiras) e, na segunda fase, apenas semeio de espécies não pioneiras.

Este modelo está sendo testado no extremo sul da Bahia (VERACEL, 2005), onde estas espécies germinam bem, sobretudo no ambiente criado após o plantio de espécies pioneiras (após um ano do plantio), no qual temos um nível de sombreamento e não existe mais concorrência com gramíneas. É um modelo que funciona bem na região sul e extremo sul da Bahia, onde temos chuvas bem distribuídas durante todo ano e não temos déficit hídrico.

\subsubsection{Plantio de estacas diretamente no campo}

A técnica de plantio de estacas pode ser utilizada com sucesso para determinadas espécies florestais e arbustivas. As limitações encontram-se no fato de que são poucas espécies a aceitar este tipo de propagação e necessidade de chuva constante, no período inicial do processo ou irrigação até pegamento das estacas e seu estabelecimento, ou exige irrigação intensa no período pós-plantio.

Várias espécies florestais nativas da floresta atlântica mostram bons resultados neste tipo de plantio, podemos citar o cedro (Cedrella fissilis e Cedrella odorata) e diversas espécies de gameleiras (Ficus spp.).

Técnicas que podem ser utilizadas para melhorar o pegamento das estacas no campo são: utilização de hormônios aceleradores de enraizamento, utilização de gel ou solução hidratante junto à cova de plantio.

\subsubsection{Semeio direto (Muvuca)}

A técnica do semeio direto, apesar de não ser muito utilizada atualmente para espécies florestais, é uma alternativa promissora, em especial se combinada com outros métodos de biológicos, podendo dar bons resultados. Entre as diversas possibilidades de combinação do semeio direto, citamos a conciliação do semeio de 
espécies secundárias tardias e clímax com o plantio de mudas de espécies pioneiras, ou leguminosas. Estas espécies, utilizadas nas etapas iniciais de plantio, criam condições de sombra e de solo especiais, e um ambiente ideal para germinação de algumas espécies, principalmente as secundárias tardias e clímax. Esta combinação de métodos reduz significativamente o custo de recuperação, e o semeio das secundárias deverá ser feito após o crescimento inicial das mudas pioneiras. Esta estratégia pode aumentar substancialmente a diversidade florística da área a ser recuperada.

Mais recentemente, a estratégia de semeio para recuperação de áreas degradadas é a técnica denominada de "muvuca", que consiste na mistura de sementes nativas arbóreas e arbustivas, muitas vezes com sementes agrícolas, para o plantio direto na área escolhida para a recuperação. A mistura das sementes das mais diferentes espécies garante a diversidade de uma floresta, visando estimular a sucessão ecológica natural com o mínimo de intervenção, além de enriquecer e proteger o solo para o efetivo desenvolvimento das espécies nativas. Conforme recomendado (ISA, 2009), em cada cova aberta, deve ser plantada a muvuca de sementes - com árvores, feijões, maracujás, flores etc. - usando de 30 a 100 sementes por metro quadrado.

\subsubsection{Semeadura aérea}

A semeadura aérea ou chuva de sementes é um método biológico, recomendado para ser utilizado, sobretudo em áreas de difícil acesso, onde é inviável operacionalmente a utilização de outros métodos, são utilizadas principalmente espécies pioneiras e em menor intensidade, sementes de espécies secundárias iniciais. Este método foi utilizado com sucesso pela Secretaria de Meio Ambiente, de São Paulo, em 1990, para áreas serranas de floresta atlântica, localizada nas imediações de Cubatão (São Paulo), onde foram adotados os seguintes critérios para seleção de espécies: ocorrência natural na região semeada; distribuição nos estratos herbáceos, arbustivos e arbóreos; alto potencial de dispersão da espécie; alto poder de germinação das sementes; rápido crescimento; alta agressividade na ocupação da área considerada; resistência à poluição atmosférica; disponibilidade de sementes para coleta na região. Porém existem limitações na escolha das espécies a serem utilizadas, em função do tipo de semente (dormência, tamanho e outros fatores). 
Após a realização do semeio aéreo, deve ser feito o monitoramento dos locais semeados, visando acompanhar o desempenho das espécies nas condições de campo. O enriquecimento das capoeiras, formadas na primeira fase, pode ser feito em etapas posteriores, através do plantio manual de espécies arbóreas típicas de estágios mais avançados da sucessão florestal, que exigem certo grau de sombreamento para seu estabelecimento.

As principais limitações da semeadura aérea são: o custo, o grau de compactação e degradação do local a ser recuperado e disponibilidade de sementes compatíveis com o método - tamanho adequado ao semeio e beneficiamento (peletização) e regime de dormência.

Este método pode dar bons resultados em áreas de difícil acesso, com precipitações altas e bem distribuídas e solo pouco compactado na superfície.

\subsubsection{Hidrossemeadura}

Trata-se de uma técnica mecanizada, em que as sementes são lançadas na área a ser recuperada através de jateamento (utilizando uma bomba), em mistura de água, sementes, fertilizantes e outros produtos como agentes cimentantes, com função de aderir a semente à superfície na qual foi aplicada.

Em nosso país, esta técnica tem sido utilizada principalmente na contenção de taludes de estradas e de áreas de mineração, atualmente produz bons efeitos, principalmente quando é combinada com alternativas, como o uso de telas naturais e plantio de mudas.

\subsubsection{Plantio adensado}

É um modelo desenvolvido para ser utilizado em áreas, nas quais temos problemas de invasão com plantas herbáceas (por exemplo, gramíneas invasoras), que competem, grandemente, com as mudas arbóreas plantadas e onde não queremos aplicação de herbicidas. Pina-Rodrigues et al. (1997) aplicaram este método para áreas cobertas com capim colonião (Panicum maximum), utilizando o espaçamento 1,o x 1,o metro (10.000 plantas por hectare), com linhas de espécies pioneiras alternadas com linhas de espécies pioneiras e não pioneiras alternadas, visando obter rápido recobrimento (e 
sombreamento) do solo, reduzindo assim os custos de manutenção. Com o espaçamento reduzido, temos igualmente um rápido recobrimento do solo, controlando a ocorrência das espécies herbáceas invasoras, porém, devido à alta densidade de mudas por hectare, o custo de implantação deste modelo é elevado. Portanto este modelo somente deverá ser utilizado, quando temos sérios problemas com plantas invasoras ou quando temos necessidade de promover uma cobertura rápida, conferindo grande proteção a alguma área degradada (problemas relacionados à grave erosão no solo - voçoroca ou sulco - ou áreas degradadas com solo exposto).

\subsubsection{Plantio de leguminosas}

O plantio de mudas de leguminosas arbóreas, que fixam nitrogênio atmosférico, é uma boa alternativa para áreas em condições de maior degradação ambiental, no lugar em que as camadas superficiais do solo foram retiradas ou fortemente alteradas. Nestas áreas, este grupo de árvores tem efeito bastante positivo, pois, geralmente, possui rápido crescimento e é capaz de melhorar o solo, depositando matéria orgânica. Segundo Dias (1996), o uso de leguminosas arbóreas noduladas e micorrizadas na recuperação de áreas degradadas, tem se mostrado como técnica viável, não só pelo seu baixo custo, como também pela grande capacidade de adaptação e de crescimento destas espécies. A quantidade de N2 fixado ocorre em função do ambiente e dos organismos envolvidos no processo, em espécies de leguminosas florestais relatam-se quantidades de até $500 \mathrm{~kg} / \mathrm{ha} /$ ano (CAMPELLO, 1996).

As leguminosas arbóreas (85\% delas são arbóreas e perenes), em especial aquelas que permitem nódulos, contribuem para recuperação do solo pela deposição de folhedo, aumentando significativamente o teor de matéria orgânica do solo. Também obtemos bons resultados com leguminosas arbustivas. Espécies, como o feijão-bravo do Ceará (Canavalia brasiliense (Jacq.) D.C.), crotalaria (Crotalaria anargyroides), cunhã (Clitoria ternatea L.) e mucuna preta (Mucuna aterrima (P\&T.) Merr.), mostraram bom desenvolvimento em experimentos conduzidos no município de Itaguaí, estado do Rio de Janeiro (VALCARCEL; D’ALTÉRIO, 1988).

Os estudos sobre leguminosas que, inicialmente, eram concentrados somente em espécies exóticas têm-se voltado ultimamente 
também para as espécies nativas, onde já temos espécies e estirpes de rizóbio mais eficientes.

\subsubsection{Recuperação com uso de espécies frutíferas}

O plantio de espécies nativas frutíferas é um modelo bem interessante para proporcionar alimento e atração da fauna silvestre. A formação de pomares de espécies frutíferas para fauna silvestre (não para o homem) permite fornecimento de alimentos para a fauna silvestre. Este modelo pode ser aplicado em áreas próximas a fragmentos florestais, onde vai fomentar a migração de animais da área florestal para a área em restauração, esta migração vai trazer propágulos da floresta original para a área florestal em recuperação. Podem-se usar, neste modelo, espécies frutíferas com capacidade de alimentar vários grupos de fauna (aves, morcegos, roedores etc.), desde que tenhamos conectividade com fragmentos florestais nos quais existam estes grupos de animais.

\subsubsection{Ampliação Ecológica de Fragmentos Florestais}

Tomando como base a situação atual presente e visualizando a necessidade de estabelecimento de novas estratégias de restauração ecológica que promovam uma rápida recuperação da área florestal, restabelecendo o processo sucessional e a sustentabilidade destes fragmentos florestais, está sendo testada e desenvolvida uma nova estratégia de restauração ecológica que toma, como referência básica e ponto de partida, os fragmentos florestais de melhor qualidade ambiental (alto valor de conservação) que ainda mantêm o processo sucessional ativo. A técnica da "Ampliação Ecológica de Fragmentos Florestais" contempla como estratégia a restauração da biodiversidade, partindo das áreas núcleo de alta diversidade ainda existente - fragmentos florestais de floresta primária ou em estágios avançado de regeneração (com alta diversidade de espécies). A promoção da expansão da área do fragmento existente, através de plantios de rápido crescimento nas bordas destes fragmentos florestais, possibilita a redução do efeito de borda e a expansão da área física destes fragmentos florestais, ampliando habitats florestais vizinhos aos fragmentos florestais de alto valor de conservação, permitindo a expansão dos recursos de flora e fauna silvestres e aumentando, consequentemente, a área núcleo destes fragmentos. Esta alternativa surge, dentro 
da situação atual da Mata Atlântica, como uma nova alternativa de promover a restauração ecológica deste bioma e outros ecossistemas fragmentados, tomando como referência e ponto de partida a matriz mais bem conservada (fragmento florestal sustentável).

Esta técnica interfere também no componente faunístico do ecossistema atlântico, pois o aumento da área de fragmentos florestais em bom estado de conservação, onde ainda temos populações animais representativas, é uma das estratégias para propiciar o aumento destas populações, de suma importância como dispersor de sementes do componente florístico (mais de 70\% das espécies da floresta atlântica são zoocóricas, isto é, dependem de animais para sua propagação).

9.1.17 Recuperação ambiental de ecossistemas com invasão de espécies exóticas

Hoje, temos muito presente o problema em relação à situação de áreas naturais, invadidas por espécies exóticas, em muitas áreas florestais e, geralmente, em todos os biomas. A invasão de espécies exóticas pioneiras perturba toda a organização do ecossistema, desde a composição florística e fitossociológica original até relação e interação flora e fauna. Recentemente, tem-se discutido muito, na área de conservação e restauração, a eliminação de espécies exóticas de áreas naturais, principalmente em unidades de conservação. Como exemplo de invasões por espécies exóticas invasoras, citamos muitas restingas no litoral brasileiro. Esta invasão atinge níveis onde se fazem necessárias ações de recuperação ambiental destas áreas invadidas para evitar o total extermínio das espécies nativas daqueles ambientes. Em áreas, nas quais temos invasão de espécies exóticas e descaracterização dos ecossistemas e espécies originais, é importante planejarmos a substituição gradual das espécies exóticas pelas espécies nativas daquele ambiente que está sendo recuperado.

\subsection{Estratégias auxiliares de apoio à recuperação ambiental}

\subsubsection{Utilização de matéria orgânica}

Esta técnica vem sendo utilizada como auxiliar na recuperação de áreas degradadas, sempre conjugada com outros métodos 
produzindo bons efeitos. Conforme a região brasileira, vêm sendo utilizados vários tipos de materiais orgânicos (casca de arroz, bagaço de cana, moinha de carvão, capim) com a intenção de promover o controle da erosão, conservação de água e melhoria da qualidade física e química dos solos. A aplicação da matéria orgânica proporciona uma redução da amplitude da temperatura do solo e aumenta a capacidade de absorção de água, proporcionando também uma recolonização com macro e microrganismos (aumentando a comunidade de microrganismos do solo), além de possibilitar o fornecimento de propágulos de plantas, garantindo o sucesso do processo de recuperação.

Em experimentos conduzidos em áreas de empréstimo, situadas na Ilha da Madeira, município de Itaguaí, estado do Rio de Janeiro, constatou-se que a deposição de matéria orgânica é o ponto chave no processo de "construção" do solo, atuando, sobretudo na melhoria das propriedades físicas do solo (VALCARCEL; D'ALTÉRIO, 1988).

Podemos, então, citar várias consequências decorrentes desta prática:

a. Melhoria da capacidade de retenção e infiltração da água, elevando o nível do lençol freático e aumentando consequentemente a resistência das plantas nos períodos de estiagem.

b. Mecanicamente, melhora a estrutura do solo especialmente quanto à aeração, descompactação e agregação de partículas primárias.

c. Diminuição dos efeitos maléficos da erosão, garantindo imediata proteção do solo. Antes de se decompor, a matéria orgânica atua como anteparo, protegendo o solo do impacto direto das gotas de chuva e atenuando o escoamento superficial.

d. Inoculação de microrganismos, como fungos micorrízicos que ampliam a eficiência do sistema radicular das plantas presentes. Além disto, a matéria orgânica favorece a atividade microbiana por sua capacidade termorreguladora.

e. Aumento do nível de absorção de nutrientes, principalmente equilibrando a absorção de nutrientes solúveis. 


\subsubsection{Uso da manta orgânica florestal (serrapilheira)}

A manta florestal é a camada superficial do solo de uma floresta, constituída por todo material solto depositado na superfície do ecossistema florestal, ou seja: folhas, restos de flores, pequenos galhos em decomposição e repleto de microrganismos, insetos e sementes de plantas herbáceas, arbustivas e arbóreas (IBAMA, 1990). A manta florestal também é designada por serapilheira, manta morta, forest litter, leaf litter. Segundo Molchanov (1971), a manta orgânica é constituída por três camadas: a superior, pouco decomposta; a média, medianamente decomposta; e a inferior, bem decomposta, onde há uma mistura de partículas minerais e matéria orgânica. No perfil do solo, designa-se por "Ao" a manta florestal, alguns autores denominam esta camada de horizonte "O" do solo. A serapilheira representa um verdadeiro banco genético de tudo que ocorre no ambiente natural.

Segundo Martins (2012), esta técnica se baseia na coleta de amostras do solo superficial e sua deposição nas áreas degradadas, além do banco de sementes serão depositados na área degradada nutrientes, associações micorrízicas e matéria orgânica, porém deve ser usada apenas como forma de aproveitamento da camada superficial do solo florestal para os casos em que o licenciamento ambiental autorizou a supressão da vegetação (aproveitamento através do resgate da manta florestal).

Como método de recuperação, a aplicação da manta florestal proporciona uma redução da amplitude da temperatura do solo, aumenta a capacidade de absorção de água, provocando a recolonização de macro e microrganismos, proporcionando um aumento da comunidade de microrganismos do solo, além de possibilitar o fornecimento de propágulos de plantas, garantindo, assim, o sucesso do processo de recuperação. A serapilheira acumulada é um importante reservatório de elementos que pode conferir maior estabilidade ao sistema, além de proteger o solo e atenuar com isso as forças erosivas. Além disso, na manta florestal, podemos encontrar um farto banco de sementes, importante no aceleramento do processo de recuperação. As sementes observadas na manta florestal são principalmente de espécies pioneiras, talvez as mais importantes na reabilitação, por germinarem somente na presença de boa luminosidade (lucíferas), quando existe algum distúrbio. 
A utilização da manta florestal, no processo de reabilitação de áreas degradadas por diversas atividades, pode acelerar em muito o processo de recuperação destas áreas, melhorando as condições químicas, físicas e biológicas do solo, justificando o seu uso. Conforme citado pelo IBAMA (1990), o uso da serapilheira muitas vezes surpreende: tem sido observado, em muitas regiões, que as plantas nascidas dela dão uma cobertura mais rápida e densa ao solo que o uso de espécies exóticas forrageiras.

Dois fatores devem ser levados em conta no planejamento do uso da manta florestal: a disponibilidade de fontes de serapilheira nas proximidades e as características da área a ser recuperada. Segundo o IBAMA (1990), a coleta da manta florestal para a aplicação em recuperação deve ser feita na época das chuvas, nas áreas circunvizinhas e com as mesmas características da área degradada a ser recuperada. Esta coleta deve ser feita com o uso de um rastelo, nunca cavando o solo, juntando o material solto da superfície e colocando-o em sacos plásticos ou balaios. É também recomendado aplicar o material o mais rápido possível após a colheita, e realizar a coleta da serapilheira em áreas alternadas ou em faixas, promovendo o recobrimento da área coletada através de ancinhos, ou outras ferramentas, com material das áreas vizinhas, evitando deixar solo exposto.

Quanto à aplicação da serapilheira, o IBAMA (1990) recomenda que sejam seguidos os seguintes passos:

a. espalhar manualmente o material na superfície, sem incorporação ao solo, na época das chuvas e no mesmo dia;

b. se possível, colocar uma camada de 10,0 cm de espessura, no mínimo;

c. no caso de bancadas, seja nos terraços, seja onde foi feito o plantio de espécies herbáceas nos taludes, a serapilheira deve ser aplicada após o plantio de herbáceas.

Estudos mostram que existe uma relação entre dinâmica de ecossistemas e estações do ano, com deposição de manta florestal. Regra geral, os ecossistemas tropicais, como a floresta atlântica, acumulam mais manta orgânica que as florestas situadas em regiões temperadas. Durante o ano, nos períodos nos quais temos maior temperatura e precipitação, é também maior o acúmulo de 
manta orgânica. Em áreas de floresta atlântica, podemos chegar a mais de 10 toneladas \hectare \ano de matéria orgânica depositada.

O banco de sementes presente na manta florestal vai, se exposto ao solo, gerar plântulas e mudas importantes para restauração da área a ser recuperada.

\subsubsection{Utilização de telas naturais}

O uso de telas confeccionadas, a partir de fibras naturais, tem grande utilidade, principalmente nos trabalhos de recuperação em áreas de declives. As telas naturais possuem a função de reter o solo destas encostas, reduzindo a erosão, estabilizando o ambiente e permitindo a germinação e o estabelecimento da vegetação. É uma estratégia de apoio para ser conciliada com métodos biológicos de restauração, geralmente semeadura a lanço ou hidrossemeadura.

A utilização de telas naturais tem-se intensificado muito na última década, hoje temos várias telas patenteadas no mercado, à base de fibras naturais. Este método derivou-se do uso de sacos de aniagem (abertos sobre o solo ou fechados, contendo terra, adubo e sementes) e telas sintéticas (plástico e metal), métodos antes utilizados em estradas de rodagem e ferrovias, para contenção de voçorocas e em minerações, sobretudo na região montanhosa do estado de Minas Gerais.

Em áreas menores, ainda hoje é utilizada a técnica de sacos de aniagem emendados, pela facilidade de se encontrar o material nas diferentes regiões e preparo da "tela". Segundo Einloft et al (1997), o uso de técnica de revegetação com sacos de aniagem permite um rápido e abundante recobrimento vegetal no talude, favorecendo a colonização pela fauna microbiana do solo e o estabelecimento de outras plantas.

As telas naturais são de fácil aplicação, pois vêm em forma de rolos e são lançadas como um tapete sobre as encostas. Apresentam como principais vantagens sua característica biodegradável e a promoção de uma excelente contenção de taludes, e como desvantagem: o custo por unidade de área.

\subsubsection{Aplicação de organismos e microrganismos}

No processo de recuperação de áreas degradadas, o componente solo deve ser tratado observando seus aspectos físicos, 
químicos e biológicos. Do ponto de vista biológico, a fauna microbiana do solo exerce forte interação, através dos processos de decomposição da matéria orgânica e liberação de nutrientes, com outros componentes do ecossistema, contribuindo para sua estabilidade. Segundo Campello (1996), o manejo das associações simbióticas pode melhorar de forma considerável o desempenho silvicultural e econômico de diversos plantios florestais, isto se aplica também, em recuperação de áreas degradadas, reduzindo os custos relativos à fertilização.

A utilização de organismos e microrganismos na recuperação está sempre associada à utilização de outros métodos biológicos ou mecânicos. Como principais benefícios da aplicação deste método, citamos: melhoria na absorção de nutrientes, aumento da taxa de absorção de água, aumento da resistência ao ataque de patógenos, melhoria das propriedades do solo, aumentando a fertilidade, melhorando a solubilidade e a reciclagem de nutrientes.

No caso de inoculação de leguminosas, a escolha correta da estirpe de rizóbio é de fundamental importância, visto que já na fase de produção de mudas, as plântulas já respondem positivamente à inoculação.

Outro grupo de microrganismos de grande importância são as micorrizas, associações formadas entre alguns tipos de fungos e raízes de algumas espécies vegetais. As micorrizas atuam como extensões do sistema radicular aumentando a área de contato e a capacidade das raízes absorverem nutrientes. Estes microrganismos se destacam por sua capacidade de absorver íons de baixa mobilidade no solo, melhorando significativamente a absorção de fósforo pelas plantas. Os fungos micorrízicos são responsáveis pela interação entre planta e solo, e podem ser inoculados de diferentes formas, destacando-se a inoculação através de terriço e esporocarpos.

Portanto, a utilização de microrganismos seja na inoculação de mudas nos viveiros, seja diretamente nos locais degradados pode constituir um meio eficiente no auxílio à recuperação de áreas.

\subsubsection{Colocação de poleiros artificiais}

A colocação de poleiros artificiais oferece ponto de pouso para aves que, ao permanecerem nestes locais, defecam, trazendo sementes de espécies provenientes de outras áreas florestais. Em 
trabalho realizado, com o objetivo de analisar a influência de poleiros artificiais na dispersão de sementes (MELO, 1997), na região de Curvelo/ MG, área de cerrado, foi demonstrado que ocorreram mais sementes nos poleiros que nas áreas sem poleiros, e o efeito da distância da fonte de sementes é muito grande neste método.

Este método apresenta algumas vantagens, quando próximo a fontes naturais de sementes, mas deve ser analisado cuidadosamente, pois o plantio de mudas de árvores funciona como poleiros vivos, podendo produzir frutos, atraindo ainda mais as aves para a área e maximizando a velocidade e a diversidade da recuperação.

\subsection{Desenho de sistemas florestais de uso múltiplo}

Sistemas florestais de uso múltiplo são modelos de recuperação ambiental de áreas degradadas onde contemplamos, além dos aspectos ambientais, as funções sociais e econômicas da futura floresta a ser formada. A aplicação de sistemas florestais de uso múltiplo para recuperação ambiental tem uma grande aplicabilidade. Considerando aspectos socioeconômicos e ambientais, envolvidos na recuperação de áreas degradadas, este tipo de modelo tende a ser de grande finalidade em programas a serem desenvolvidos em área de floresta atlântica. $\mathrm{O}$ estímulo econômico, conciliado a aspectos sociais e ambientais e ao atendimento de aspectos legais, torna os modelos de uso múltiplo promissores para serem adotados por órgãos públicos em programas de fomento e por empresas em programas de recuperação. Em ecossistemas florestais bem manejados, são perfeitamente compatíveis atividades de produção florestal e a conservação ambiental. Estes modelos são adequados para áreas onde queremos recuperar a floresta e conciliar atividades produtivas à futura floresta em recuperação.

Na recuperação ambiental, utilizando modelos de sistemas florestais de uso múltiplo, procuramos conciliar a obtenção de benefícios ambientais (conservação do solo, da fauna, flora e água) com a produção de benefícios econômicos (coleta de produtos florestais madeireiros e não madeireiros). A equação para desenho de um modelo ideal deve considerar, em primeiro lugar, o ecossistema original da região e seu processo sucessional, entretanto também são incorporadas variáveis socioeconômico-ecológicos que permitam custear a recuperação em longo prazo e garantir a sustentabilidade do sistema. 
Sistemas florestais de uso múltiplo se distinguem dos sistemas agroflorestais (SAF's), por possuírem somente o componente arbóreo e terem como objetivo principal os aspectos ambientais, isto é, conciliar a rentabilidade econômica com a proteção ambiental, não possuindo componentes agrícolas e animal (doméstico). É um sistema de uso menos intensivo que os SAF's, se aplicado melhor em propriedades médias e grandes, com grande vantagem de poder ser investido em áreas de reservas. No desenho de sistemas florestais, é necessário conhecer profundamente o funcionamento do ecossistema florestal original da região, que fornecerá toda base teórico-científica de informações para o desenvolvimento de modelos de uso múltiplo. A floresta atlântica tropical úmida com toda sua diversidade, complexidade e dinamismo é a base do conhecimento para o desenho destes sistemas. Portanto, em sistemas florestais na recuperação ambiental de áreas de floresta atlântica, devemos considerar como grande aliado à biodiversidade deste ecossistema, o que nos dá grande plasticidade no desenvolvimento de modelos e, consequente, capacidade de adaptação em diversas situações de degradação. A grande diversidade pode resultar em dificuldade de manejo, porém, nos modelos de uso múltiplo, somente algumas espécies são incorporadas ao componente produtivo (menor número de espécies, maior facilidade de manejo).

O conhecimento do processo de sucessão natural - mencionado no capítulo 5 - é de conhecimento indispensável no planejamento de modelos de recuperação ambiental e torna-se mais importante quando anexamos variáveis sociais e econômicas ao processo de planejamento. A mãe natureza é nossa grande professora e a observação dos laboratórios naturais - áreas degradadas e florestas em diferentes estágios sucessionais - são importantes, porém conhecimentos sobre a dinâmica de funcionamento de diferentes ecossistemas, armazenados em estudos, realizados por institutos de pesquisas e universidades, nunca deverão ser desprezados.

\subsubsection{Seleção de espécies}

Além de todos os critérios para seleção de espécies discutido no capítulo 7, especificamente no caso de sistemas florestais de uso múltiplo, devemos incorporar critérios especiais, considerando principalmente espécies de importância econômica. Grupos 
de plantas de importância econômica, pertencentes à flora regional - plantas medicinais, ornamentais, produtoras de alimentos, fibras e outras -, merecem destaque especial nestes modelos, pois eles vão fazer parte do componente econômico do sistema, responsável por sua sustentabilidade (custeio de operações de implantação e manutenção do sistema). Para análise imediata, é interessante trabalharmos com espécies que tenham um mercado conhecido, cuja série histórica de preços do produto seja possível de ser levantada e analisada. Todo trabalho de desenvolvimento de modelos é dinâmico e contínuo, portanto a pesquisa de novos produtos florestais deve ser constante, melhorando sempre o componente socioeconômico dos sistemas florestais de recuperação a serem implantados, potencializando a capacidade de sustentabilidade do sistema. Apesar da redução significativa da área de floresta atlântica, este bioma abriga ainda uma rica biodiversidade.

\subsubsection{Modelagem}

No desenho destes modelos de recuperação (sistemas florestais), é necessária grande habilidade do planejador, que deve buscar conciliar o melhor uso dos recursos disponíveis (luz, água, nutrientes, espaço físico, energia, mão de obra e capital), propiciando, além da recuperação ambiental da área degradada, a melhoria da renda líquida por área, aperfeiçoamento da qualidade do site e de vida dos proprietários. Esta visão holística é necessária para a condução dos trabalhos desde a fase de diagnóstico da região até a implantação dos modelos em escala comercial, devendo existir uma constante reavaliação e reajuste dos modelos. Observa-se que, quanto maior a quantidade de espécies inseridas no componente econômico do modelo, mais complexo fica seu manejo nas fases de estabelecimento e coleta, também fica mais complexa sua avaliação, tanto econômica como social e ambiental. No desenho de modelos de uso múltiplo, devemos buscar um equilíbrio entre número de espécies "econômicas" utilizadas e facilidade de manejo.

Após a escolha das espécies a serem utilizadas, deve ser definido sua distribuição espacial e densidade de plantio nos diferentes ambientes presentes na área a ser recuperada.

É muito importante, na fase de análise econômica, a realização de análises individuais das diferentes espécies que compõem 
a parte econômica do sistema, classificando-as conforme sua importância dentro do sistema. Estas análises permitem definir um número ideal de espécies econômicas (produtos) dentro do sistema, dentro de um limite, quando é possível realizar um "bom manejo" florestal.

As espécies de importância econômica, que vão ser utilizadas nestes modelos, devem ser introduzidas de forma a facilitar a operação de coleta de produtos, o ideal, na maioria dos casos, é o plantio em linhas, construído dentro da floresta que está sendo formada. Nestas linhas, desenhadas em espaçamentos predeterminados, as mudas plantadas podem ser mais bem manejadas, facilitando também a operação de coleta.

Citamos como vantagens dos sistemas florestais de uso múltiplo:

a. benefícios sociais, já que temos necessidade constante da mão de obra, após ativação do sistema - início da fase produtiva;

b. possibilidade de coleta de produtos conforme programação do agricultor - poupança verde - podendo aguardar época de "sobra" de mão de obra na propriedade ou região;

c. maior diversidade, maior equilíbrio, maior aproximação do ecossistema original, quando comparado com sistemas agroflorestais;

d. é possível de se estabelecer um manejo padrão (pacote) de fácil compreensão por parte dos executores (rotina de trabalho);

e. possibilidade permanente de ajustes e introdução de novas plantas produtivas do ponto de vista econômico;

f. possibilidade de utilização de culturas agrícolas no início da implantação, barateando custos iniciais de implantação;

g. podem ser aplicados, em áreas de reserva legal, com pequenas adaptações na fase de desenho e modelagem, moldam-se às características legais regionais (estaduais).

Como exemplo de ilustração de sistemas florestais de uso múltiplo, mostramos, na figura 4, o perfil de um sistema florestal de 
uso múltiplo, desenhado para recuperação de áreas ciliares e florestas de encosta, no extremo sul da Bahia. Este modelo foi desenvolvido pelo autor, juntamente com mais outros quatro modelos, para recuperação ambiental de áreas de florestas ripárias e de encostas, situadas dentro dos projetos de reflorestamento com eucalipto da Veracel Celulose S.A. O modelo mostrado possui como característica a utilização exclusiva de espécies da floresta atlântica regional e, dentro do componente econômico dos sistemas, estão previstos somente com produtos não madeireiros.

A utilização de sistemas florestais tem grande importância na conservação dos demais recursos naturais, pois o ecossistema florestal consiste, principalmente, em áreas tropicais, na vegetação que melhor protege o solo contra a ação erosiva e mantém recursos hídricos em qualidade e quantidade suficientes, fornecendo também abrigo e alimento para a fauna silvestre. Este sistema, se bem manejado, pode conciliar a função protetora ambiental com o manejo sustentável e a coleta de produtos florestais (nem sempre isto significa madeira), contudo, no projeto de desenvolvimento de sistemas florestais, é necessário incorporar conceitos e conhecimentos de autoecologia das espécies, da sucessão florestal e da dinâmica dos fragmentos florestais.

FOTO 13 - Modelo de recuperação ambiental com uso múltiplo, plantio de palmeiras piaçavas, produtoras de fibras, plantio em linhas. Área experimental da Veracel Celulose. Eunápolis, Bahia

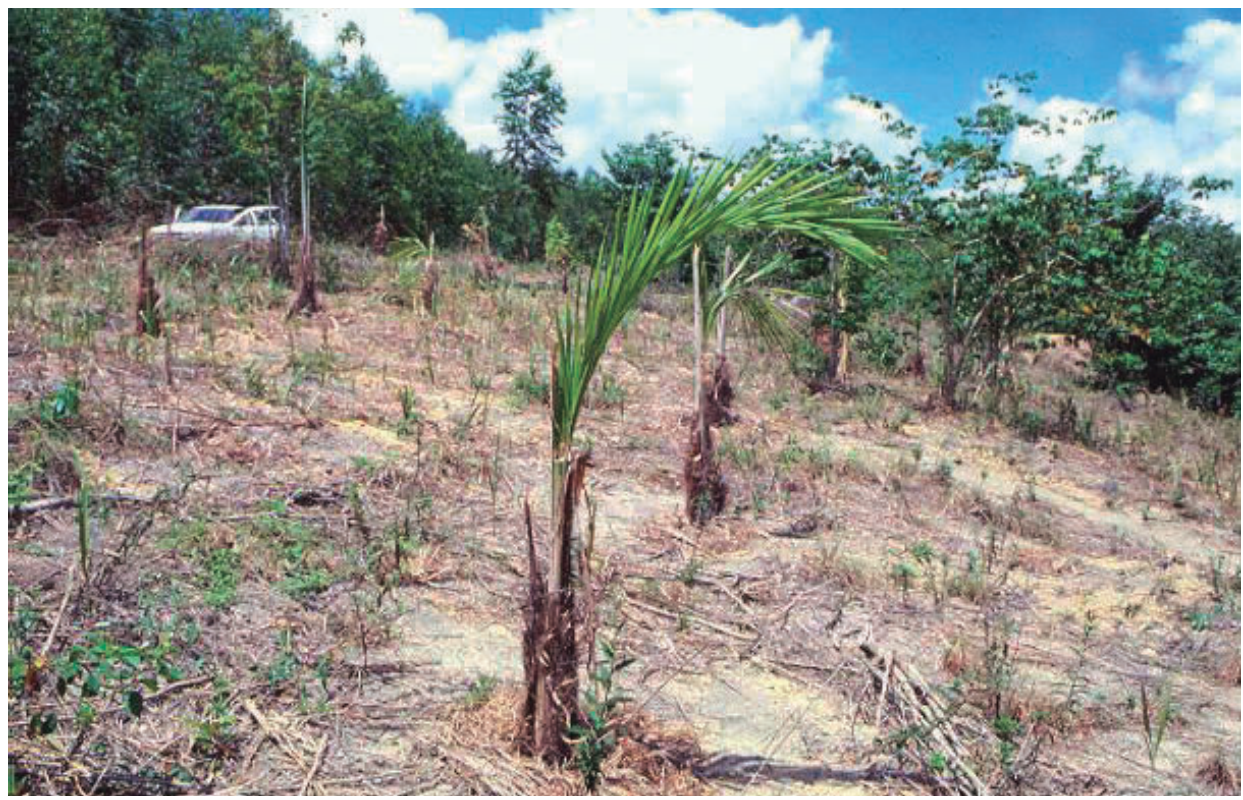


FIGURA 4 - Modelo de sistema florestal de uso múltiplo, utilizando somente plantas da floresta atlântica regional (componente econômico com piaçava e palmito), desenvolvido pelo autor para recuperação de matas ciliares e de encosta, localizadas dentro dos cultivos de eucalipto da Veracel Celulose S.A.. Extremo sul da Bahia

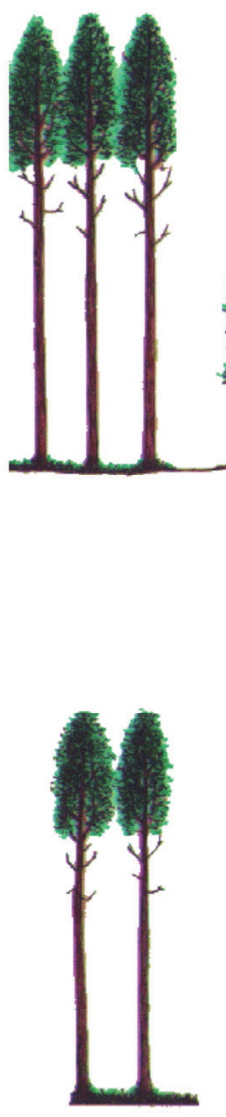

PLANTIO GOMERGIAL

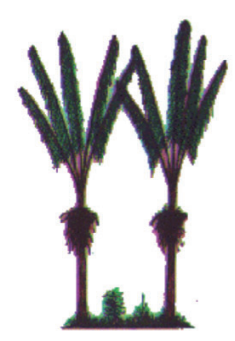

PIAQAVA

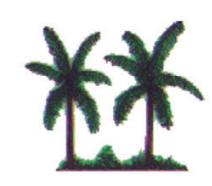

PALMITO (JUÇARA)

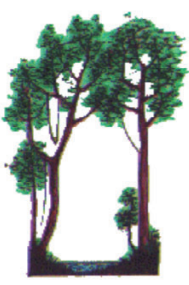

MATA CILIAR

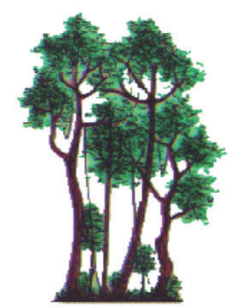

FLORESTA RECUPERADA

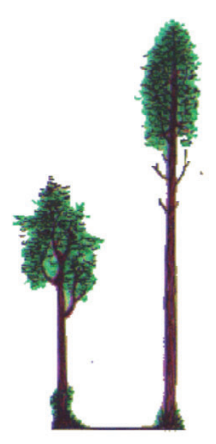

ACEIRO 


\subsection{Modelos de enriquecimento de fragmentos florestais}

Hoje, os fragmentos florestais, em sua maioria, se encontram degradados, devido ao isolamento, extrativismo (vegetal e animal) passado e ausência de dispersores de sementes. Estes fragmentos possuem muitas espécies raras e muitas outras espécies desapareceram da área pelo extrativismo (espécies madeireiras, por exemplo). Estes modelos de enriquecimento são utilizados para aumentar a diversidade de fragmentos florestais, propiciando a retomada do processo de sucessão natural da área, que, na maioria das vezes, se encontra estagnada.

Normalmente, este modelo é aplicado em fragmentos florestais de florestas secundárias, em fragmentos florestais em estágio inicial e médio de regeneração de Mata Atlântica que possuem pequena diversidade de espécies. É um método bom para matas secundárias jovens e com pouca diversidade de espécies (geralmente presente em fragmentos florestais isolados). O enriquecimento pode ser implantado de três distintas maneiras:

\section{Plantio em Faixas}

O plantio em faixas é realizado dentro das áreas dos fragmentos florestais, e a distância entre as linhas deve ser aberta em distância variável, conforme estado de conservação e necessidade de intervenção na área. Segundo Galvão e Medeiros (2002), as faixas devem possuir 1 metro de largura, atravessando a área, a intervalos de 3-10 metros de distância e, dentro da mesma faixa, deverão ser abertas covas distanciadas de 2 a 5 metros entre elas.

Considerando que vamos ter um ambiente mais sombreado, as espécies a serem plantadas devem pertencer a grupos ecofisiológicos de estágios mais avançados de sucessão, preferencialmente secundárias tardias e clímax. Devemos observar os dispersores de sementes das espécies que vão ser utilizadas.

Este método pode ser modelado como um sistema de uso múltiplo com a introdução de espécies madeireiras nobres nativas nas linhas, o que facilita o manejo futuro das espécies introduzidas.

\section{Ilhas/Clareiras}

Neste sistema, o plantio é feito de maneira aleatória, buscando as grandes clareiras existentes dentro da área florestal formando 
ilhas, isto é, pequenos maciços em clareiras naturais com alta diversidade. Dependendo do tamanho da clareira, podemos plantar espécies pioneiras, secundárias iniciais, secundárias tardias e clímax. Em pequenas clareiras, devem ser priorizadas as espécies secundárias tardias ou clímax.

\section{Controle de cipós}

Em fragmentos florestais pequenos e isolados, é comum a presença de grande infestação de cipós. Esta infestação prejudica muito a regeneração natural de espécies arbóreas e o prosseguimento do processo de sucessão florestal, necessitando da prática de manejo florestal denominada controle de cipós. Considerando que estes cipós também possuem grande importância ambiental (fornecendo floração e frutificação em períodos variáveis), não é recomendável a eliminação de $100 \%$ dos cipós, mas sim somente o controle deste grupo de espécies.

\subsection{Avaliação dos modelos de recuperação ambiental}

Com objetivo de analisar e conhecer o desempenho e a aplicabilidade dos modelos propostos, são necessárias realizações de diferentes avaliações, contemplando especialmente os aspectos ambientais, sociais, econômicos e legais. Um dos grandes erros apresentados em trabalhos, na área de recuperação ambiental de floresta atlântica, é o de não se fazer uma análise holística dos modelos desenhados, considerando custos e simulando seu desempenho futuro.

No caso de recuperação ambiental, as avaliações referentes aos aspectos ecológicos são as mais importantes, pois o objetivo principal é a recomposição do ecossistema original. Os aspectos econômicos são também muito importantes, não só na consideração do custo da recuperação, mas também, na geração de receitas, como no caso dos sistemas florestais de uso múltiplo. A análise do desempenho social dos modelos é importante para agregar mais valores aos sistemas propostos, considerando a grande importância do componente social no conceito moderno de meio ambiente. Já o conhecimento da legislação em diferentes níveis - municipal, estadual e federal - é fundamental para adequarmos os modelos a estes parâmetros, e obtermos futuros certificados e selos verdes. 


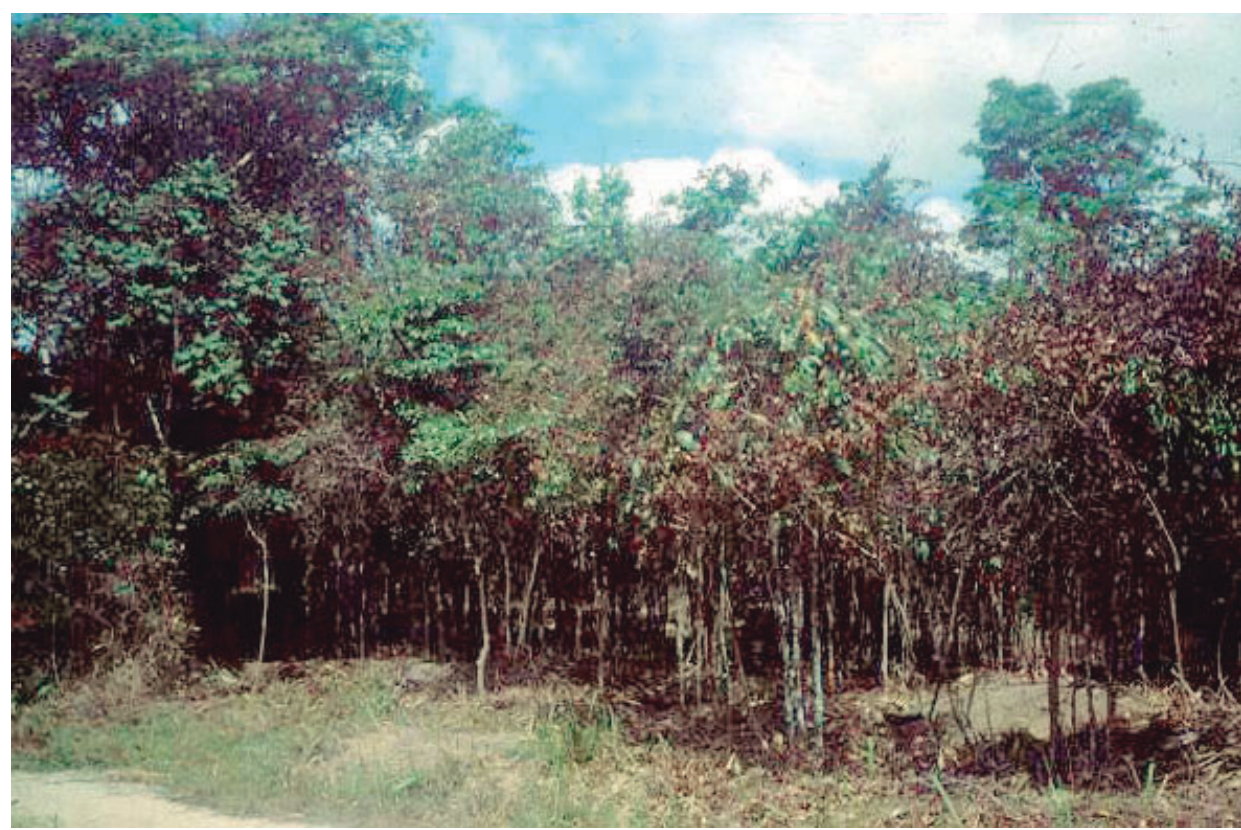

FOTO 14 - Fragmento florestal em estágio inicial de regeneração, esta área possuía grande infestação de cipós o que impedia o desenvolvimento do processo sucessional. Neste fragmento florestal foi realizado a prática de controle de cipós

\subsubsection{Avaliação ambiental}

As avaliações ambientais devem se embasar em fatores mensuráveis. Um sistema, que pode ser utilizado, é o de classificar os critérios ambientais em diferentes pesos e dar notas específicas para cada um.

Para ilustrar citamos, como exemplo, algumas características ambientais possíveis de serem mensuradas:

a. conservação de solo (em função da densidade do plantio);

b. conservação da água (monitoramento da qualidade da água antes e depois do plantio);

c. conservação de biodiversidade (baseado no número de espécies nativas utilizadas, originárias do ecossistema original que está sendo recuperado);

d. avaliação da regeneração natural (diversidade vegetal que surge após o plantio);

e. atrativo da fauna silvestre (número de espécies atrativas de fauna utilizadas). 
Estas características podem ter diferentes pesos $(1,2,3)$ e avaliadas em notas, alocando diferentes pontuações como:

1. ótimo: 10

2. bom: $8-9$

3. satisfatório: $6-7$

4. ruim/reprovado: $<6$

Finalmente, podemos construir uma tabela combinando características ambientais, pesos e notas, sendo possível comparar o desempenho ambiental dos diferentes modelos desenhados e definir os melhores do ponto de vista ambiental, dando prioridade para atingir os objetivos propostos inicialmente no projeto.

\subsubsection{Componente econômico}

Na área de domínio floresta atlântica, existe uma grande carência de informações sobre parâmetros econômicos de recuperação ambiental. O custo de recuperação pode, muitas vezes, significar um obstáculo e desestímulo para a realização de trabalhos nesta linha.

Quando falamos em modelos de uso múltiplo, em que temos também a produção econômica incorporada ao processo de recuperação, maior é a necessidade de detalhar o conhecimento do componente econômico do sistema. Sugerimos fazer uma análise econômica, enfocando vários parâmetros, para termos maior segurança na tomada de decisão, para isto, faz-se necessário incluir na equipe de planejamento um profissional da área econômica. Citamos abaixo alguns itens que devem ser considerados em uma avaliação econômica:

a. Custo total - implantação e manutenções: incluem gastos com preparo do terreno, coveamento, adubação, plantio, insumos (mudas e fertilizantes) e operações de manutenção. O profissional que trabalha nesta área deve possuir boas planilhas de custos e rendimentos de operações de recuperação. Observamos que, na faixa de floresta atlântica, existe uma variação regional muito grande, portanto estas tabelas de rendimentos e custos de mão de obra não devem ser generalizadas para todas as regiões. 
b. Tempo de carência - em sistemas florestais implantados em áreas degradadas, devemos considerar o tempo necessário até a ativação do componente econômico. Em geral, os produtos florestais não madeireiros, na região da floresta atlântica, possuem um período de tempo até iniciar sua produção, temos como exemplo o palmito juçara, que demora em torno de oito anos para início da produção.

c. Lucro bruto (R $\$ / \mathrm{ha} / \mathrm{ano})$ - é o total de receitas obtidas a partir da ativação total da produção do sistema, essa análise econômica deve ser feita em planilhas nos componentes que são incorporados ao sistema produtivo ao longo dos anos. Em função do modelo de recuperação a ser adotado, este custo de implantação pode variar entre $\mathrm{R} \$ 0,60$ a $\mathrm{R} \$ 2,00$ por muda plantada, para o sistema tradicional de plantio de mudas de espécies arbóreas, baseado em dados de Jesus (1994), Piña-Rodrigues et al (1997) e Almeida (1997).

d. Taxa interna de retorno (TIR) - para o cálculo da TIR, são utilizadas taxas de custo de capital. Os parâmetros utilizados objetivam avaliar o projeto da forma mais realista possível.

É importante ressaltar que, como qualquer projeto agrícola, a recuperação ambiental é influenciada por intempéries climáticas, de difícil previsão, portanto se aconselha que o projeto seja aceito somente se o resultado da TIR tiver sido bastante superior ao custo de capital, cobrindo os riscos do sistema. Porém devemos considerar que o objetivo principal dos sistemas é promover a recuperação ambiental e não, exclusivamente, obter lucros, fazendo muitas vezes com que a análise seja feita de forma mais abrangente, não se exigindo uma TIR tão superior ao custo de capital.

e. Valor presente líquido (VPL) - permite fazer comparações entre diferentes opções de modelos, considerando a mesma taxa de desconto, deve-se aceitar o projeto que tiver o maior VPL.

Vale lembrar que, nem sempre, o projeto com o maior VPL é o que possui a maior TIR. Deve-se, portanto 
fazer uma avaliação concomitante entre as duas formas de análise de investimento. Normalmente, os projetos devem ser aceitos se forem viáveis economicamente nas duas análises, ou se fazer uma média ponderada dos resultados obtidos comparando-se as diversas possibilidades de investimento.

Informações referentes à produtividade por área, mercado consumidor devem ser as mais confiáveis possíveis e atualizadas, sendo obtidas junto a institutos de pesquisas ou através de levantamentos realizados na região.

\subsubsection{Desempenho social}

O desempenho social pode ser mensurado através de vários parâmetros como capacidade de geração de empregos, salários e benefícios, qualidade de vida e outros.

Em modelos de recuperação ambiental de uso múltiplo, podemos observar um grande potencial de geração de empregos permanentes. $\mathrm{O}$ número de empregos gerados nas fases de implantação e manutenção, assim como aqueles gerados na fase de colheita, deve ser baseado em rendimentos operacionais médios praticados na região do projeto.

Neste item, devemos fazer projeções da capacidade de geração de empregos, ao longo de horizonte de tempo, principalmente para sistemas de uso múltiplo, nos quais temos a incorporação parcelada de novos produtos e consequente geração gradativa de novas oportunidades de trabalho.

O sistema de organização da mão de obra nas diferentes etapas, desde a implantação até a colheita, também deve ser bem conhecido: empreiteiro-prestador de serviços, microempresas responsáveis por determinadas áreas, cooperativa, associação de coletores ou funcionários da empresa empreendedora. Serviços de beneficiamento e industrialização de produtos, oriundos dos sistemas florestais de uso múltiplo, podem maximizar os benefícios sociais.

\subsubsection{Aspectos legais}

Já foram discutidos, no capítulo 3, os aspectos legais ligados à recuperação ambiental. Na fase de avaliação, é interessante 
termos uma ideia espacial - zoneamento - das diferentes áreas especiais citadas na legislação. É importante saber se estamos dentro, vizinhos ou próximos a alguma unidade de conservação (pública ou particular), e se a área é de preservação permanente, reserva legal ou se encaixa em outra categoria de conservação. Principalmente, quando os objetivos da recuperação não envolvem somente recuperação ambiental, como no caso dos modelos de uso múltiplo, esta análise deve ser rigorosa, estudando as possíveis limitações legais após a ativação do sistema florestal e início da coleta de produtos.

A legislação deve ser conhecida em diferentes níveis, desde o âmbito municipal até o federal. Por exemplo, atualmente em alguns estados brasileiros não é possível a coleta seletiva de madeira nas áreas de reserva legal, em outros é possível realizar esta retirada de maneira sustentável. 


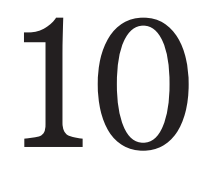

\section{PLANO DE RECUPERAÇÃO DE ÁREAS DEGRADADAS (PRAD)}




\subsection{Definições gerais}

$\mathrm{P}$ RAD significa plano ou projeto de recuperação de áreas degradadas, que tem como objetivo principal criar um roteiro sistemático, contendo as informações e especificações técnicas organizadas em etapas lógicas, para orientar a tecnologia de recuperação ambiental de áreas degradadas ou perturbadas para alcançar os resultados esperados. Segundo a Fundação para Conservação e a Proteção Florestal do Estado de São Paulo (2004), o projeto técnico é um instrumento de planejamento, execução e avaliação. O PRAD teve sua origem no artigo 225, da Constituição Federal de 1988, e no Decreto-Lei n. 97.632/89, que regulamentou a Lei n. 6.938/81, obrigando a recuperação da área degradada como parte do Relatório de Impacto Ambiental, podendo ser empregado de forma preventiva ou corretiva, em áreas degradadas por ações de mineradoras. No início, o PRAD era aplicado apenas na atividade mineradora, na década de 1990, foi estendido como forma de condicionante e ajustes de conduta ambiental para outras atividades degradadoras, sendo incorporado como um programa complementar da maioria dos Estudos de Impacto Ambiental e Relatórios de Impacto Ambiental e em Termos de Ajuste de Conduta (TAC), firmados entre empresas e o Ministério Público. Grande parte dos trabalhos de recuperação ambiental, originários de PRAD, tem origem nas imposições da legislação brasileira. Mais recentemente, outro dispositivo legal, a Instrução normativa n. 4, de 13 de abril de 2011, estabelece procedimentos para elaboração do PRAD ou Área Alterada. Esta instrução traz como anexos Termos de Referência, e distingue dois tipos de PRAD (PRAD e PRAD simplificado), que são aplicados conforme cada caso especificado na norma. Na instrução é determinado que "o PRAD deve reunir informações, diagnósticos, levantamentos e estudos que permitam a avaliação da degradação ou alteração e a consequente definição de medidas adequadas à recuperação da área".

O PRAD é conduzido conforme objetivos discutidos com o proprietário (ou proponente), alinhados com o técnico responsável pelo projeto e acompanhamento, conforme Instrução normativa n. 4, de 13 de abril de 2011, o proprietário deve assinar também o "Termo de Compromisso de Reparação de Dano Ambiental”, que será anexado ao PRAD a ser apresentado. 
Uma observação a ser considerada é que uma parte considerável dos PRAD, apresentados e aprovados por órgãos ambientais, na prática, não são implantados. Existe uma necessidade dos órgãos ambientais estaduais e municipais acompanharem a implantação destes PRAD.

Hoje, normalmente, existem, em vários estados, roteiros ou termos de referência para elaboração de PRAD, neste capítulo, mostramos um roteiro mais geral e mais utilizado de forma normal no Brasil. É recomendado que um projeto técnico contivesse os seguintes itens básicos: introdução, objetivos, metas, metodologia, sistema de monitoramento e avaliação, cronograma de execução, recursos materiais, humanos e financeiros, e anexos (FUNDAÇÃO PARA CONSERVAÇÃO E A PROTEÇÃO FLORESTAL DO ESTADO DE SÃO PAULO, 2004).

\subsection{Procedimentos e métodos para elaboração de PRAD}

\subsubsection{Considerações e planejamento inicial}

O processo de recuperação ambiental é complexo, requerendo tempo, recursos (dinheiro, mão de obra e tecnologia) e conhecimento dos diversos fatores relacionados à área a ser recuperada, como as características do solo, da água, da fauna, da flora e as modificações inerentes ao processo que ocasionam (ou ocasionarão) o distúrbio. O PRAD deve ter inicialmente seus objetivos bem definidos, ajustando variáveis como: as necessidades legais, desejo do proprietário do terreno, aspectos sociais e econômicos. Nunca esquecendo de que o objetivo principal é promover a recuperação ambiental de uma área degradada.

O planejamento inicial prevê a necessidade da confecção de um roteiro que busque a solução mais rápida, mais eficiente e mais econômica para se recuperar as áreas degradadas faz-se necessário conhecer o passado, analisar o presente e planejar o futuro das áreas a reabilitar. O planejamento deve ser com uma visão de longo prazo. O processo de planejamento deve ser realizado, projetando-se em longo prazo e contemplando sempre uma visão global do problema. Os "pacotes" e "receitas" generalistas não funcionam no caso de recuperação, cada situação específica deve receber um 
tratamento adequado. As etapas, aqui mostradas, compõem apenas um roteiro bem simples e básico, que pode ser adaptado para cada caso específico.

Hoje, um PRAD deve considerar em seu escopo, além dos aspectos ambientais, as variáveis sociais e ambientais, envolvidas no processo de recuperação. Os atores sociais (população que, originalmente, ocupava a área degradada e entorno, incluindo seus valores e interesses) assim como a atividade econômica, que era desenvolvida na área antes da intervenção (impacto) ambiental, devem ser considerados.

Uma das etapas mais importantes a ser considerada é o diagnóstico que permite o conhecimento da amplitude dos problemas ambientais, sociais e econômicos envolvidos no processo de recuperação ambiental da área e respectivo PRAD. O diagnóstico prévio de aspectos ambientais (biológicos) e socioeconômicos permite que se estabeleçam metas para a recuperação ambiental, dando mais consistência ao PRAD e a seu processo de implementação.

O sucesso e a garantia de implantação do projeto de recuperação são oriundos do gerenciamento responsável dos recursos e das atividades envolvidas, que vão garantir a implantação do projeto, a responsabilidade técnica dos autores dos projetos que devem, obrigatoriamente, acompanhar tecnicamente a implantação e manutenção do PRAD. Em empresas que possuem as respectivas áreas ambientais, este projeto e acompanhamento poderão ser feitos por técnico do próprio quadro da empresa, porém a maioria dos PRAD é elaborada e supervisionada por profissionais terceirizados (consultores).

Todo planejamento para implantação do PRAD não deve ser voltado somente para os interesses e necessidades do empreendedor, mas também para o sucesso do plano, considerando os aspectos biológicos, físicos, socioculturais, econômicos, políticos, na qual a área objeto do PRAD está inserida.

Nesta primeira etapa, devemos considerar as pretensões e objetivos do proprietário com referência ao destino da futura área, aspectos e obrigações legais, envolvidos com o problema, e realizar um levantamento do histórico de ocupações da área a ser recuperada (revisão bibliográfica e fotográfica sobre a região, histórico de utilização da área e informações sobre a área antes da degradação - vegetação, fauna, hidrografia, clima, atividades antrópicas). 
10.2.2 Identificação dos agentes de degradação

Fazer o levantamento dos agentes de degradação que atuaram e ainda agem sobre a área a ser recuperada, proporcionando a continuidade da degradação dos recursos naturais.

\subsubsection{Delimitação das áreas de influência}

Delimitar a área de influência direta (que está degradada), na qual devemos concentrar os trabalhos de diagnóstico e estudos referentes ao meio físico e biológico (estudo do substrato atual e área de influência indireta, o entorno), que deve ser considerada com referência aos aspectos socioeconômicos, além dos biológicos e físicos de referência (áreas similares à original que ainda permanecem intactas).

\subsubsection{Avaliação do grau de degradação}

Devem ser avaliados o estado atual do substrato (solo) da área e a capacidade de regeneração biótica da vegetação.

\subsection{Elaboração do projeto de recuperação - roteiro básico}

10.3.1 Parte introdutória

a. Introdução - resumo geral do PRAD, onde são citados o estado ambiental da área degradada, os objetivos e as metas do projeto.

b. Objetivos - descrição dos objetivos gerais e específicos esperados com a implantação do PRAD.

c. Metas - descrição das metas pretendidas.

d. Caracterização da região - esta parte deve conter uma breve caracterização biológica, física e climática da região, com enfoque na propriedade onde está inserida a área degradada. Informações sobre o clima regional, variação anual de temperatura e precipitação, tipos de solos, classificação e caracterização da vegetação, malha viária e uso atual predominante. Estas características devem ser 
descritas superficialmente neste item inicial e detalhadamente na fase de diagnóstico da área a ser recuperada.

e. Equipe técnica do PRAD - descrição da equipe técnica responsável pela elaboração do PRAD. Conforme estado e grau de degradação, podemos ter um PRAD elaborado por um só profissional ou por uma equipe técnica. Por exemplo, citamos uma atividade de mineração, quando temos necessidade de Geólogo/Engenheiro Florestal/ Agrônomo/Biólogo complementarmente.

\subsubsection{Caracterização do Empreendimento}

a. Informações Gerais - nome, endereço, CEP, telefone, área degradada, atividade e substância retirada, responsável técnico pela atividade degradadora inicial.

b. Licenciamento ambiental da atividade inicial - relação de todas as licenças ambientais existentes no empreendimento e respectivos condicionantes. Deve conter licenciamentos ambientais de funcionamento e supressão de vegetação.

c. Localização e acesso - deve conter roteiro de acesso ao empreendimento, além de croqui ou mapa com localização das estradas de acesso, e demarcação das áreas a serem exploradas.

d. Área degradada - área requerida, área prevista inicialmente, área com outras atividades, área de serviço de apoio, área total efetivamente utilizada.

e. Mão de obra - pessoas envolvidas em cada atividade na exploração da área.

f. Período de funcionamento - horário de funcionamento da atividade exploratória.

\section{g. Informações sobre a atividade exploratória}

i) Reservas

ii) Estimativa de produção (estoque de terra, argila, minério etc.).

iii) Produção - previsão de produção periódica e total da área.

iv) Tempo de utilização da área a ser explorada - tempo que irá durar a atividade. 
v) Métodos utilizados - descrição de qual metodologia a ser empregada em cada processo.

vi) Equipamentos a serem utilizados - relação de equipamentos e quantidades a serem utilizados na atividade exploratória.

vii) Descrição do processo de beneficiamento - descrição do processo final de beneficiamento, principalmente em pedreiras e minerações.

viii) Controle de poeira e ruído - outros tipos de poluição que devem ter controle previsto no PRAD. Geralmente, o trânsito intenso de caminhões e a geração de poeiras requerem um sistema de irrigação de estradas.

ix) Bota-fora - área destinada a depósito de estéreis e restos de construção do empreendimento. Esta área receberá no PRAD um tratamento especial para recuperação. Deve ser observada a composição do bota-fora, fatores, como a presença de metais pesados, requerem técnicas complementares de recuperação e segurança.

x) Ações contra erosão - medidas como a construção de sistema de drenagem, construção de canaletas, escadas de água, caixas e outros.

xi) Segurança do trabalho e placas de sinalização previsão da colocação de placas, e técnicas de segurança a serem adotadas.

xii) Armazenamento da camada superficial do solo - deve ser previsto o local de armazenamento da camada superficial do solo, esta operação é muito importante para o processo de recuperação ambiental da área degradada.

\subsection{Diagnósticos Ambientais}

Esta etapa compreende todas as observações e levantamentos de campo, como:

a. identificação e avaliação dos impactos;

b. mapeamento das diferentes unidades de paisagem; 
c. caracterização física e química (limitações dos solos, nível de fertilidade) dos solos, análises biológicas e químicas da água;

d. estudos faunísticos - grupos de espécies bioindicadoras e dispersores; relação flora/fauna, dispersores, polinizadores;

e. estudos da flora - observações de campo (curto prazo) e levantamentos florísticos e fitossociológicos (longo prazo).

Destacamos a importância do conhecimento dos estratos herbáceo, arbustivo e arbóreo, pois, em função do estágio de degradação da área a ser recuperada, faz-se necessária a recomposição a partir de estratos inferiores (herbáceos). Caso a área já se encontre degradada, temos de tomar como referências áreas vizinhas similares para estudos de vegetação, solos, fauna e outros necessários.

10.4.1 Caracterização do meio físico

a. Geologia e Geomorfologia - classificação e caracterização geológica da área a ser explorada e vizinhança.

b. Clima - informações gerais sobre o clima como precipitação média mensal, relação e média das temperaturas, velocidade dos ventos etc. Grande parte destas informações pode ser obtida nos órgãos estaduais, ligados à Secretaria de Agricultura e Meio Ambiente, e federais (de pesquisa como EMBRAPA, CEPLAC) que, muitas vezes, possuem estações meteorológicas e têm séries históricas de dados climáticos.

c. Solos - tipos de solos existentes na área explorada.

d. Hidrologia e qualidade das águas superficiais e subterrâneas - descrição dos recursos hídricos, incluindo bacia hidrográfica na qual a área a ser explorada está incluída.

\subsubsection{Caracterização do meio biótico}

i) Flora - o ideal é a descrição da composição florística, os estudos fitossociológicos são importantes para subsídios aos projetos de recuperação ambiental. 
ii) Fauna - descrição da fauna presente na área e vizinhança. Vai subsidiar a possível formação de corredores que pode ser obtida com a recuperação ambiental da área degradada.

10.4.3 Caracterização do meio socioeconômico

Estudos relativos às características sociais e econômicas da atividade, e da vizinhança (entorno).

\subsection{Plano de recuperação das áreas degradadas (Reconstituição do meio ambiente)}

a. Impactos ambientais negativos do empreendimento - descrição dos impactos, caso exista um EIA/RIMA, este poderá servir de referência. Pode ser feito na forma de listagem de impactos ou matriz de impactos. As medidas mitigadoras de cada impacto devem fazer parte deste PRAD.

b. Processo de degradação - desmatamento, decapeamento, utilização de explosivos, ruídos e poeira, emissão de poeira, ruídos, bota-fora.

c. Recomposição topográfica e paisagística - tratos na superfície do terreno evitando declives abruptos e taludes inclinados.

d. Tratos da superfície final - preparo do solo para etapas finais da recuperação, isto é, revegetação.

e. Obra de Engenharia - em áreas inclinadas, é indispensável, para contenção do processo erosivo, a instalação de uma rede de drenagem. Deve ser observada a compatibilidade do clima e do solo com as obras civis e revegetação previstas. Construção de barragens de rejeitos é necessária em alguns casos, como, por exemplo, áreas inclinadas com solo arenoso, certas áreas mineradas etc.

f. Relocação da camada fértil do solo - a camada superficial do solo, que é retirada e armazenada no início do empreendimento, deve ser novamente distribuída na superfície da área a ser recuperada.

g. Redução do grau de compactação do solo - etapa que deve ser prevista no caso da existência de grande compactação 
dos solos, devido, principalmente, ao trânsito de máquinas e caminhões.

h. Correção da fertilidade do solo - deve conter as análises química e física, quando as condições do solo estiverem muito alteradas quanto à compactação e ao adensamento do substrato (solo). Compreende as recomendações sobre aplicação de corretivos e de adubação.

i. Estratégias (metodologia) para recomposição da vegetação - envolve todo trabalho de restabelecimento da vegetação original, compreendendo etapas como: definição dos métodos biológicos de recuperação de áreas degradadas, seleção das espécies a serem utilizadas, definição dos modelos de recuperação a serem empregados, técnicas de preparo da área, manutenção, etc.

Este item deve conter a descrição detalhada de:

- Especificações técnicas - espaçamento (tomado também com base nos estudos fitossociológicos), medidas das covas (berço), necessidade de adubação, seleção de espécies, definição das estratégias de recuperação a serem utilizadas.

- Operações a serem realizadas com respectivos rendimentos operacionais - limpeza da área (manual ou mecanizada), coroamento, coveamento, plantio, adubação.

- Necessidade e quantificação de equipamentos de proteção individual (EPI), ferramentas, máquinas.

- Insumos necessários - é a relação das espécies a ser utilizada (espécies nativas selecionadas com base nos estudos florísticos e resultados fitossociológicos, separando -os em grupo ecofisiológicos, contendo nomes vulgares, nomes científicos, família), adubos necessários (fórmulas e quantidades), iscas formicidas e calcário.

j. Custos e produtividade - nesta parte, devem constar os custos referentes a cada operação programada, assim como rendimentos operacionais de cada operação prevista no projeto. Estas informações técnicas, operacionais e financeiras são importantes referências para orientação de futuros projetos de recuperação de áreas degradadas. Portanto é necessário programar temporariamente os custos do projeto, ajustando, com o cronograma operacio- 
nal, o desembolso necessário para implantação do PRAD.

k. Cronograma de execução - o cronograma serve como referência temporal para o acompanhamento técnico e orçamentário de liberação de recursos de todas as etapas previstas no projeto de recuperação. Todo suporte técnico, administrativo e financeiro é baseado no cronograma. No caso de um projeto de recuperação ambiental, não podemos deixar de considerar, entre outros, os fatores climáticos e sazonalidade regional da mão de obra.

1. Sistema de monitoramento e avaliação - a etapa de monitoramento compreende o acompanhamento contínuo, quando é avaliado o desempenho da estratégia de recuperação ambiental utilizada, permitindo eleger as práticas de recuperação ambiental mais adequadas para alcançar os objetivos predeterminados para a reabilitação do ambiente. Devem ser tomadas como referência as condições iniciais (referências iniciais antes da recuperação e logo após a recuperação) e o objetivo final que pretendemos alcançar, por exemplo, em uma área de floresta tropical, onde a área degradada era ocupada antes por floresta tropical, nosso objetivo é recuperar este ecossistema. O conjunto de variáveis biológicas, químicas e físicas deve ser utilizado de maneira sistemática, ao longo do tempo. Observamos a importância do monitoramento ambiental nos processos de tomada de decisões gerenciais e técnicas, envolvidas no processo de implantação de PRAD e recuperação ambiental da área, os resultados com certeza vão indicar novas práticas a serem adotadas na área em recuperação.

Para o monitoramento, é utilizada uma série de indicadores como:

i) Meio físico - geralmente são monitoradas as propriedades químicas dos solos, como $\mathrm{pH}$ em água, carbono orgânico total, $\mathrm{P}, \mathrm{K}$, disponível, $\mathrm{Ca}, \mathrm{Mg}$ e Al trocáveis, soma de bases e capacidade de troca de cátions efetiva e a $\mathrm{pH}$ 7. Outras análises específicas para a área recuperada podem ser utilizadas. Estas análises podem ser realizadas semestral ou anualmente. 
- Variáveis químicas dos solos - quantificação da matéria orgânica e a condutividade elétrica da solução do solo.

- Variáveis físicas - estrutura, densidade do solo, resistência ao penetrômetro, capacidade de retenção de água e profundidade média do sistema radicular das espécies de maior presença.

ii) Da mesma maneira, pode ser monitorada a qualidade da água, principalmente se a área estiver próxima a algum curso de água. Esta variável poderá ser utilizada pelo acompanhamento de variáveis químicas da água - O.D. - oxigênio dissolvido, turbidez, nitrito, fosfato, $\mathrm{pH}$. Estas análises podem ser realizadas semestral ou anualmente.

m. Meio biótico - deve ser acompanhada, através da implantação de parcelas permanentes, a evolução da sucessão ecológica da vegetação, isto é, espécies presentes e novas espécies desenvolvidas na área (aumento da diversidade), permitindo comparações com a vegetação primitiva. Indicadores como densidade de plantas por área, regeneração natural, riqueza de espécies botânicas, índices de diversidade e de similaridade entre áreas, além da produtividade em termos de crescimento da biomassa acima do solo, crescimento em altura e diâmetro das espécies presentes são bons indicadores da evolução do processo de regeneração natural.

Também podem ser feitos monitoramentos da fauna silvestre que pode ser monitorada através de grupos bioindicadores como avifauna ou formigas. Normalmente as análises do meio biótico (flora e fauna) podem ser realizadas anual ou bianualmente.

n. Manutenção de plantios - talvez, uma das etapas mais importantes, em todo processo de recuperação de uma área degradada, seja a manutenção da vegetação implantada. Em função, principalmente da presença de plantas invasoras na área (que vão competir ou até mesmo matar as mudas das espécies introduzidas), deve 
ser planejada a frequência das manutenções. Em áreas antes ocupadas por determinados tipos de gramíneas, como braquiárias ou colonião, por exemplo, se faz necessário, na maioria das vezes, a aplicação de herbicidas, até o estabelecimento do componente arbóreo e sombreamento, quando estas gramíneas sairão naturalmente do sistema.

Em áreas, em que a aplicação de herbicidas pode comprometer o sistema, o custo de recuperação (devido ao custo de manutenção) é elevado, assim, podemos utilizar a matéria orgânica morta ao redor das mudas. A camada orgânica, colocada ao redor das mudas (coroa), garante a umidade do solo e evita o surgimento de plantas competidoras com as que foram implantadas. Muitos materiais se prestam para formar esta cobertura morta, e, em especial, quando buscamos recuperação ambiental em áreas que estão cobertas por gramíneas (principalmente gramíneas agressivas do tipo braquiária), esta proteção tem papel fundamental. Existe uma grande deficiência na pesquisa de materiais para a formação de camada orgânica morta ao redor das mudas (mulching), esta proteção tem efeitos fantásticos, eliminado custos de manutenção e garantindo o sucesso do plantio. Uma boa opção, na roçada e no coroamento, é colocar toda matéria orgânica, oriunda destas operações, ao redor das mudas, visando manter a umidade do solo e evitar o aparecimento de plantas competidoras ao redor das plântulas introduzidas. A roçada, quando necessária, deve ser realizada em linhas, sempre acompanhando o sentido das curvas de nível do terreno que está sendo recuperado.

No serviço de limpeza inicial do terreno, onde já existe algum tipo de cobertura, esta nunca deverá ser completamente eliminada, pois estas plantas exercem um papel importante na proteção e na conservação dos solos. Deve ser eliminada somente a vegetação que compete diretamente com as mudas plantadas, sendo este controle feito através de coroamento (ao redor das mudas) ou em linhas (nas linhas de plantio). 
o. Bibliografia

p. Anexos - fotos, plantas ou croqui de localização e Anotação de Responsabilidade Técnica (ART), obtida junto ao CREA.

\subsection{Avaliação de PRAD}

No Brasil, esta é uma das atividades que tem muito a evoluir, hoje é necessário treinamento dos técnicos de órgãos ambientais ligados à análise de PRAD, estes devem ser analisados sempre com uma visão mais ampla, observando a interligação entre as partes. $\mathrm{Na}$ análise inicial do PRAD, no escritório, devem ser observadas as informações coletadas na fase de diagnóstico, que devem ser coerentes e utilizadas nas etapas previstas para a recuperação ambiental. Todos os estudos, realizados na fase de diagnóstico, devem ser anexados ao PRAD, permitindo melhor análise. A base para a avaliação inicial do PRAD são as vistorias de campo, onde devem ser conferidas se as estratégias de recuperação, prescritas no PRAD, foram realmente implantadas. Em longo prazo, devem ser exigidos também os relatórios de monitoramento com respectivos pareceres e relatórios de laboratórios, Universidades e Instituições de pesquisa em anexo.

\subsection{Estudos de caso sobre algumas situações específicas}

\subsection{1 Áreas degradadas por mineração}

Principalmente no estado de Minas Gerais, na área de floresta atlântica e transição floresta/cerrado/campos de altitude, a recuperação de áreas mineradas vem sendo praticada há algum tempo. Vários métodos de recuperação e novas tecnologias foram desenvolvidos. Desde a Constituição de 1988, desde que a recuperação destas áreas é obrigatória, muito se tem evoluído neste sentido. As técnicas de telas (metálicas, sintéticas e naturais), hidrossemeadura e outras evoluíram e foram adaptadas para estas situações.

Hoje, todo solo retirado, na fase inicial da mineração, é armazenado durante a fase de lavra, e recolocado depois de terminada 
a retirada do minério. Esta operação facilita o trabalho de revegetação, pois temos o horizonte " $\mathrm{A}$ " presente, facilitando o estabelecimento da vegetação.

O maior problema das áreas após a mineração é a presença de taludes com grandes declives, o que inviabiliza o estabelecimento de muitas espécies; e, na maioria dos casos, esta inclinação não permite a introdução de um componente arbóreo. As empresas estão utilizando, em sua maioria, apenas o plantio de gramíneas e outras espécies herbáceas e espécies exóticas (Pinus e Eucaliptus), poucas estão se preocupando em recompor a vegetação original da área, antes da mineração.

Uma técnica empregada com muito sucesso, neste caso, é o plantio misto de mudas leguminosas herbáceas e arbóreas, fixadoras de nitrogênio atmosférico, de preferência mudas micorrizadas e inoculadas. Na etapa de seleção de espécies, devemos nos preocupar em escolher espécies que nodulem e possam crescer em condições de solos presentes nestas áreas.

\subsubsection{Florestas ciliares}

Ecossistemas de florestas ciliares, também chamados de matas ciliares, florestas de galeria, mata aluvial e florestas ripárias são florestas ocorrentes nas proximidades das margens dos cursos de água. A vegetação característica surge em função de características específicas, presentes nestes ambientes, como: solos típicos aluviais - com elevados teores de umidade, maior umidade atmosférica, temperaturas mais baixas e topografia, variando em função de características hidrológicas e geomorfológicas. Portanto, sob estas condições combinadas, surge uma vegetação típica, com composição florística e estrutura própria.

Por se tratar de um ecossistema com características específicas, quando trabalhamos com estes ambientes, devemos conhecer seu processo sucessional - composição florística e estrutura típica de cada estágio - pois é necessário um projeto específico para florestas ciliares.

$\mathrm{Na}$ área de domínio da floresta atlântica, existem vários trabalhos específicos sobre recuperação ambiental de florestas ciliares. Alguns estados, como Minas Gerais, São Paulo e Paraná já desenvolvem, há muitos anos, programas de recomposição de florestas 
ciliares e de áreas em margens de represas. Estes trabalhos são importantes referências para quem deseja se especializar ou desenvolver um projeto de recuperação destes ambientes. Existem algumas controvérsias quanto à importância das matas ciliares, para alguns especialistas, em hidrologia florestal, a recuperação de topos de morros (área de captação) seria mais importante do que a recuperação de áreas nas margens dos cursos de água. Apesar destas discussões, sabemos que as áreas de florestas ciliares exercem uma importante função tampão, protegendo os rios e influenciando muito a qualidade da água.

A FOTO 15 mostra uma área de mata ciliar bem conservada, presente nas margens do Rio Acaraí, município de Camamu, Bahia, cuja água é utilizada para abastecimento do mesmo município. Nestas áreas de matas ciliares, em bom estado de conservação, as florestas se interagem e protegem os recursos hídricos. A introdução da prática de Pagamento de Serviços Ambientais (PSA) tem como fundamento remunerar proprietários rurais destas margens, que conservam suas matas e rios. Estes proprietários futuramente podem vir a ser remunerados pela conservação destas áreas e já

FOTO 15 - Florestas ciliares em bom estado de conservação, Rio Acaraí, município de Camamu, Bahia

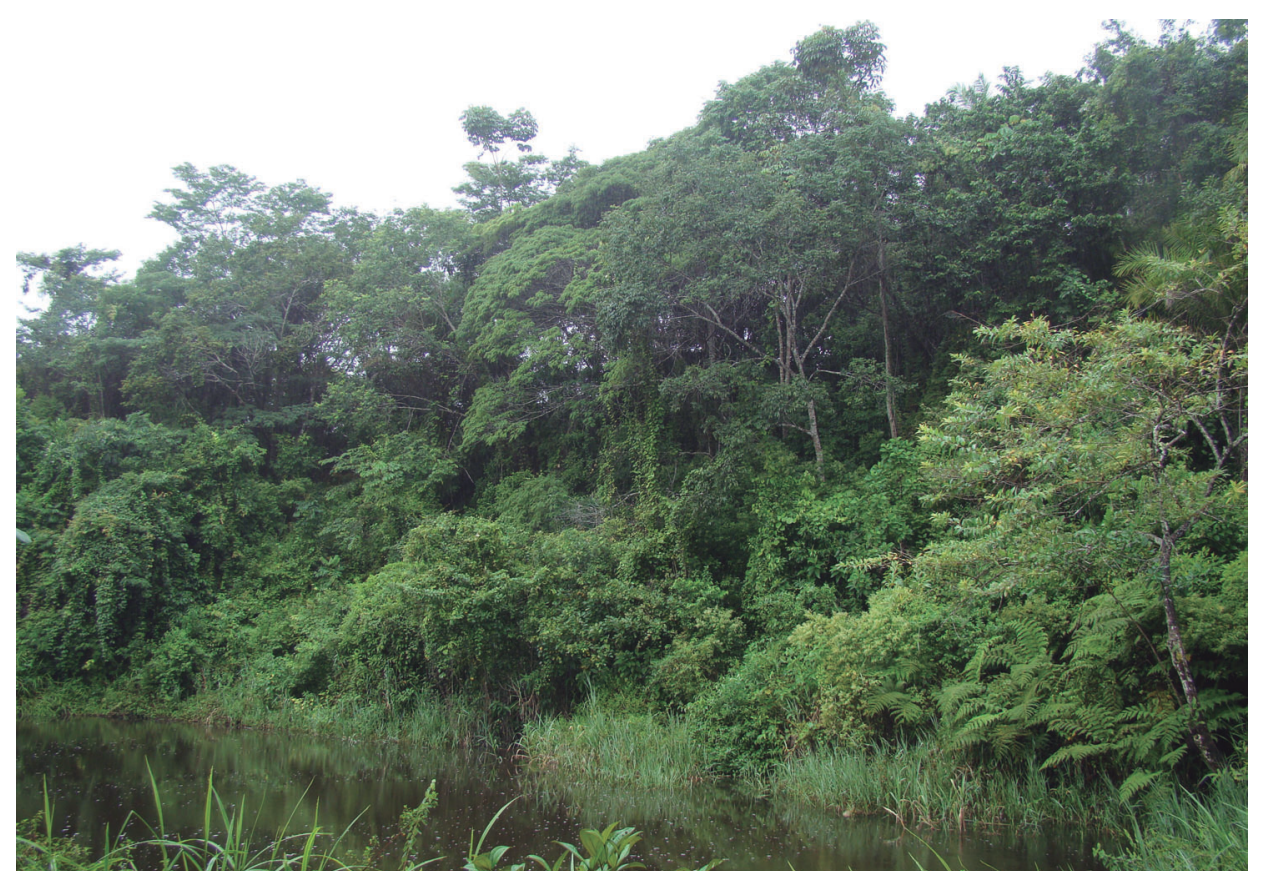


existem vários projetos desta natureza em curso em vários países e, mais recentemente, no Brasil.

10.7.3 Taludes de grandes declives em margens de rodovias

Nas áreas originárias da construção de estradas, em regiões de relevo acidentado, a recuperação destas áreas torna-se indispensável para a segurança dos transeuntes. As estradas, nas quais não são recuperadas áreas inclinadas, estão sujeitas constantemente a interrupção do tráfico, devido ao desmoronamento de encostas sobre a pista de rodagem, causando prejuízos ambientais e econômicos gerais. Além da queda de barrancos sobre a pista, o carreamento de barro para a estrada provoca grande risco de acidentes.

FOTO 16 - Sequência de recuperação ambiental de área de encosta margeando uma estrada. Estrada municipal para praia de Itaquena, Trancoso, Porto Seguro, Bahia
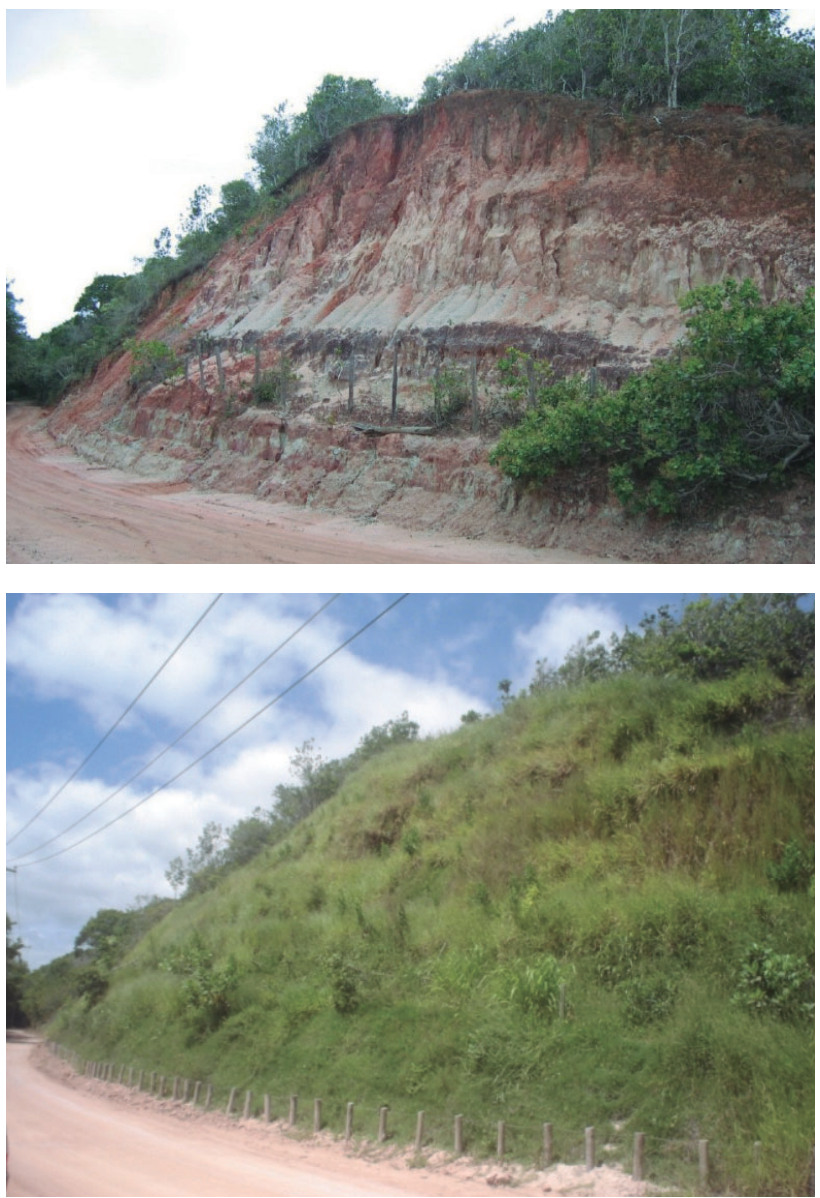
Nestes casos, em função da inclinação dos taludes, geralmente não é recomendável a utilização do plantio de espécies arbóreas na recuperação. Devemos utilizar espécies herbáceas e gramíneas que podem ser plantadas via hidrossemeadura, hidrossemeadura combinada com telas ou mudas e, em função do tamanho da encosta, o plantio direto de mudas. A FOTO 16 mostra a sequência de recuperação ambiental em área de talude na margem de rodovia municipal, estrada da praia de Itaquena, distrito de Trancoso, município de Porto Seguro.

\subsubsection{Erosão em sulco ou voçorocas}

Em função do tipo de solo, com a remoção da vegetação protetora, ele está exposto a uma constante perda de solo. Em áreas montanhosas onde o fluxo de água proveniente de chuvas se concentra em determinados canais, formam-se os sulcos ou voçorocas, que exigem um bom planejamento para sua recuperação. A eficiência do projeto de recuperação destas áreas depende da inclusão de obras de engenharia (construção de canaletas e caixas de drenagem, visando desviar a concentração do fluxo de água e esta-

FOTO 17 - Área degradada de voçoroca em processo de recuperação, através do uso de paliçadas e revegetação com espécies de gramíneas, leguminosas e bambus

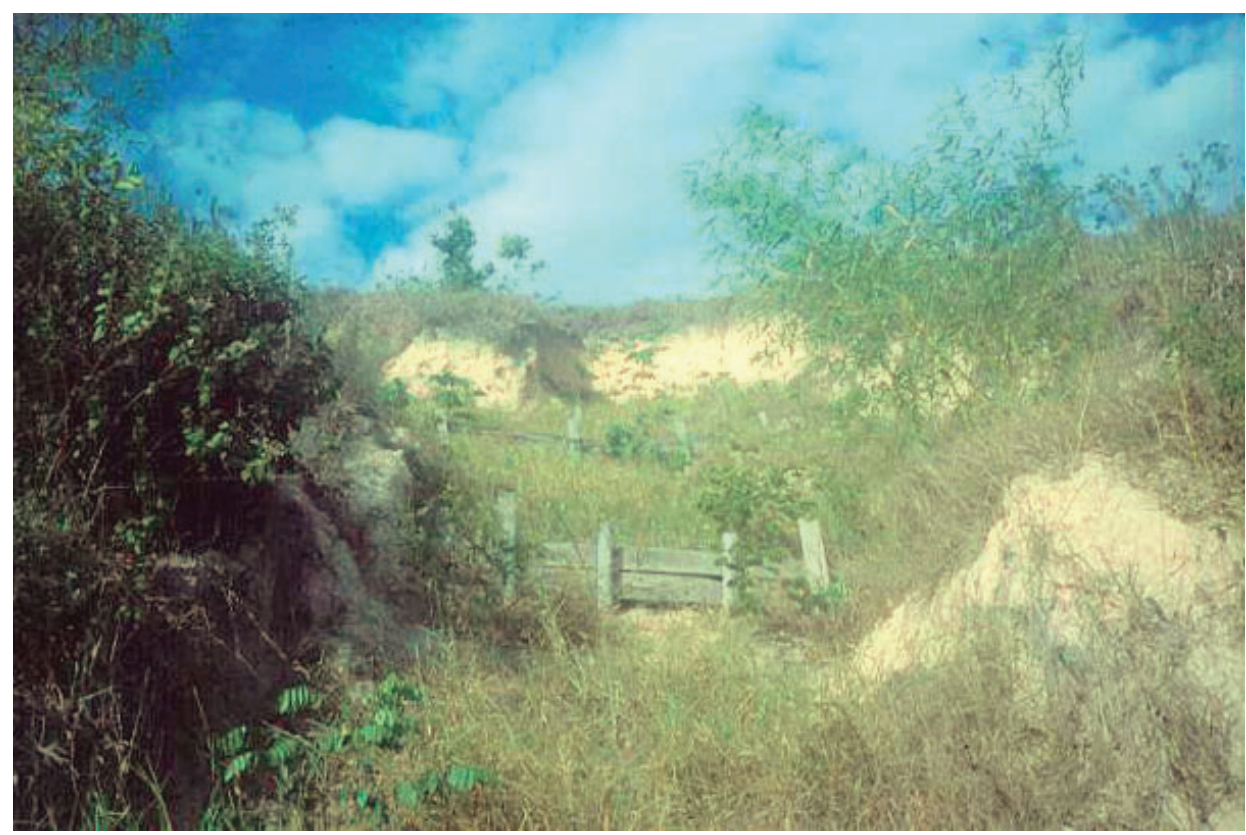


bilizar o canal principal da voçoroca). O uso de sacos de aniagem, paliçadas e outros obstáculos para o aumento do canal principal da voçoroca também são necessários na fase inicial. Somente após a estabilidade física da área, é que partimos para a utilização de métodos biológicos para revegetação e estabilização dos taludes e fundos de voçorocas e sulcos.

10.7.5 Ecossistema degradado pela presença de espécies exóticas invasoras

A presença de espécies exóticas invasoras pode causar degradação em ecossistemas naturais, estas espécies ocupam espaços/nichos, antes ocupados pelas espécies nativas, interferindo igualmente nas relações ecológicas flora/flora, flora/fauna, causando desequilíbrio nas áreas naturais, inclusive a extinção de espécies nativas. Da mesma forma, espécies exóticas da fauna tendem a aparecer nestas áreas.

Para a recuperação ambiental destas áreas, sugerimos a substituição gradual das espécies exóticas por espécies nativas, evitando formar grandes clareiras que poderiam causar impacto no solo destes ambientes. As mudas nativas devem ser reintroduzidas após o levantamento florístico e fitossociológico de áreas naturais similares. O planejamento da recuperação e um bom cronograma de ações são fundamentais para o sucesso da eliminação total das espécies exóticas e restauração com as espécies nativas.

Ressaltamos a importância desta ação especialmente em algumas áreas de restinga e florestais, próximas aos centros urbanos, quando a presença de infestação de espécies exóticas atinge um maior nível. 


$$
11
$$

\section{MANUTENÇÃO DE PROJETOS DE RECUPERAÇÃO AMBIENTAL}




\subsection{Manutenção dos plantios}

$\mathrm{U}$

ma das etapas mais importantes em todo processo de recuperação de uma área degradada é a manutenção do plantio. Em função, principalmente da presença de plantas invasoras na área (que vão competir ou até mesmo matar as mudas das espécies introduzidas), deve ser planejada a frequência das manutenções, envolvendo as operações de replantio de mudas mortas, coroamento (limpeza ao redor das mudas), adubação de cobertura, combate a formigas cortadeiras, reparos de cercas etc. Em áreas antes ocupadas por determinados tipos de gramíneas, como braquiárias ou colonião, por exemplo, faz-se necessário manter a área ao redor das mudas sem vegetação competidora. Esta limpeza ao redor das mudas pode ser realizada com aplicação de herbicidas ou capina manual (coroamento) até o estabelecimento do componente arbóreo e sombreamento, quando estas gramíneas serão naturalmente eliminadas do sistema florestal. Os problemas comumente encontrados em áreas recuperadas, gerando a necessidade de manutenção, são mostrados no QUADRO 1, abaixo:

QUADRO 1 - Problemas comuns que geram necessidade de manutenção de áreas

\begin{tabular}{|l|l|}
\hline \multicolumn{1}{|c|}{ PROBLEMA APRESENTADO } & \multicolumn{1}{c|}{ SOLUÇÕES VIÁVEIS } \\
\hline Mortalidade de mudas plantadas. & Replantio de mudas. \\
\hline Presença de vegetação competidora. & Capina mecânica ou química, roçada da área. \\
\hline Seca pronunciada. & Irrigação das mudas (manhã e final da tarde). \\
\hline $\begin{array}{l}\text { Presença de plantas competidoras } \\
\text { nas covas. }\end{array}$ & Coroamento ao redor das mudas. \\
\hline $\begin{array}{l}\text { Entrada e presença de animais } \\
\text { domésticos. }\end{array}$ & Revisão do cercamento da área. \\
\hline Risco de incêndios. & Revisar o sistema de aceiros. \\
\hline $\begin{array}{l}\text { Mudas plantadas apresentando pro- } \\
\text { blemas nutricionais. }\end{array}$ & $\begin{array}{l}\text { Aplicação de adubação de cobertura nas } \\
\text { covas das mudas plantadas. }\end{array}$ \\
\hline Ataque de formigas cortadeiras. & Combate às formigas cortadeiras. \\
\hline
\end{tabular}

Em áreas, onde a aplicação de herbicidas pode comprometer o sistema, o custo de recuperação (devido ao custo de manutenção - capinas manuais mais frequentes) é elevado, podemos utilizar algumas alternativas ao redor das mudas, visando o impedimento da formação/aparecimento da vegetação competidora. A aplicação 
de matéria orgânica (mulching) morta ao redor das mudas, papel jornal ou papelão, pode solucionar este problema, principalmente, em áreas onde não podemos fazer aplicação do herbicida. A colocação da camada orgânica (mulching), jornal ou papelão ao redor das mudas (coroa), garante a umidade do solo e evita o surgimento de plantas competidoras com as que foram implantadas. A colocação da "saia orgânica" deve ser realizada após o coroamento manual da área (limpeza com enxada ao redor das mudas). A FOTO 18 mostra área na qual foi colocado o papel de jornal ao redor das mudas, evitando a presença de vegetação gramínea competidora.

FOTO 18 - Colocação de matéria orgânica ao redor das mudas (mulch) visando inibir o aparecimento da vegetação competidora (pastagem de braquiária).

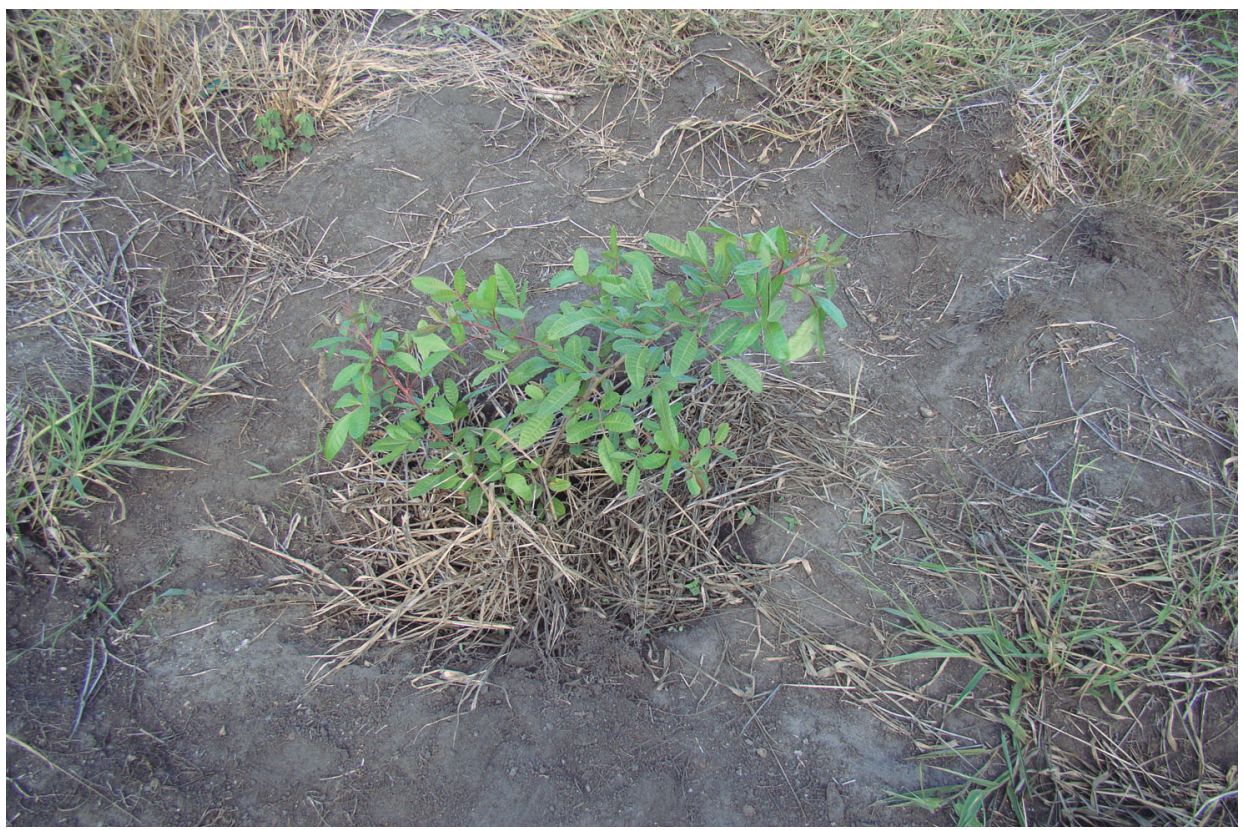

Existe uma grande deficiência na pesquisa de materiais para formação de camada orgânica morta ao redor das mudas (mulching), esta proteção tem efeitos fantásticos, eliminado custos de manutenção e garantindo o sucesso do plantio. Uma boa opção é se, na roçada e coroamento, colocarmos toda matéria orgânica oriunda destas operações, ao redor das mudas, visando manter a umidade do solo e evitar o aparecimento de plantas competidoras ao redor das plântulas introduzidas. A roçada, quando necessária, deve ser 
realizada em linhas, sempre acompanhando o sentido das curvas de nível do terreno que está sendo recuperado.

A operação de coroamento ao redor das mudas tem de ser observada e deve ser capinada, eliminando a vegetação em um raio de $60 \mathrm{~cm}$ ao redor das mudas. É importante frisar que, nesta operação, a capina e a eliminação da vegetação devem se concentrar somente ao redor das mudas, visto que, onde já existe algum tipo de cobertura, a vegetação preferencialmente não deve ser completamente eliminada, pois estas plantas exercem um papel importante na proteção e conservação dos solos. Caso esta vegetação esteja de porte mais alto, será necessária uma roçada na área de plantio, evitando a competição por luz entre a vegetação herbácea arbustiva estabelecida e as mudas plantadas.

A FOTO 19 mostra a área onde foi colocado, de forma experimental, o papelão, visando manter a umidade ao redor das mudas e reduzir o aparecimento da vegetação competidora, em especial de gramíneas.

FOTO 19 - Colocação de papelão ao redor das mudas visando inibir o aparecimento da vegetação competidora (pastagem de braquiária) e evitando o uso de herbicidas

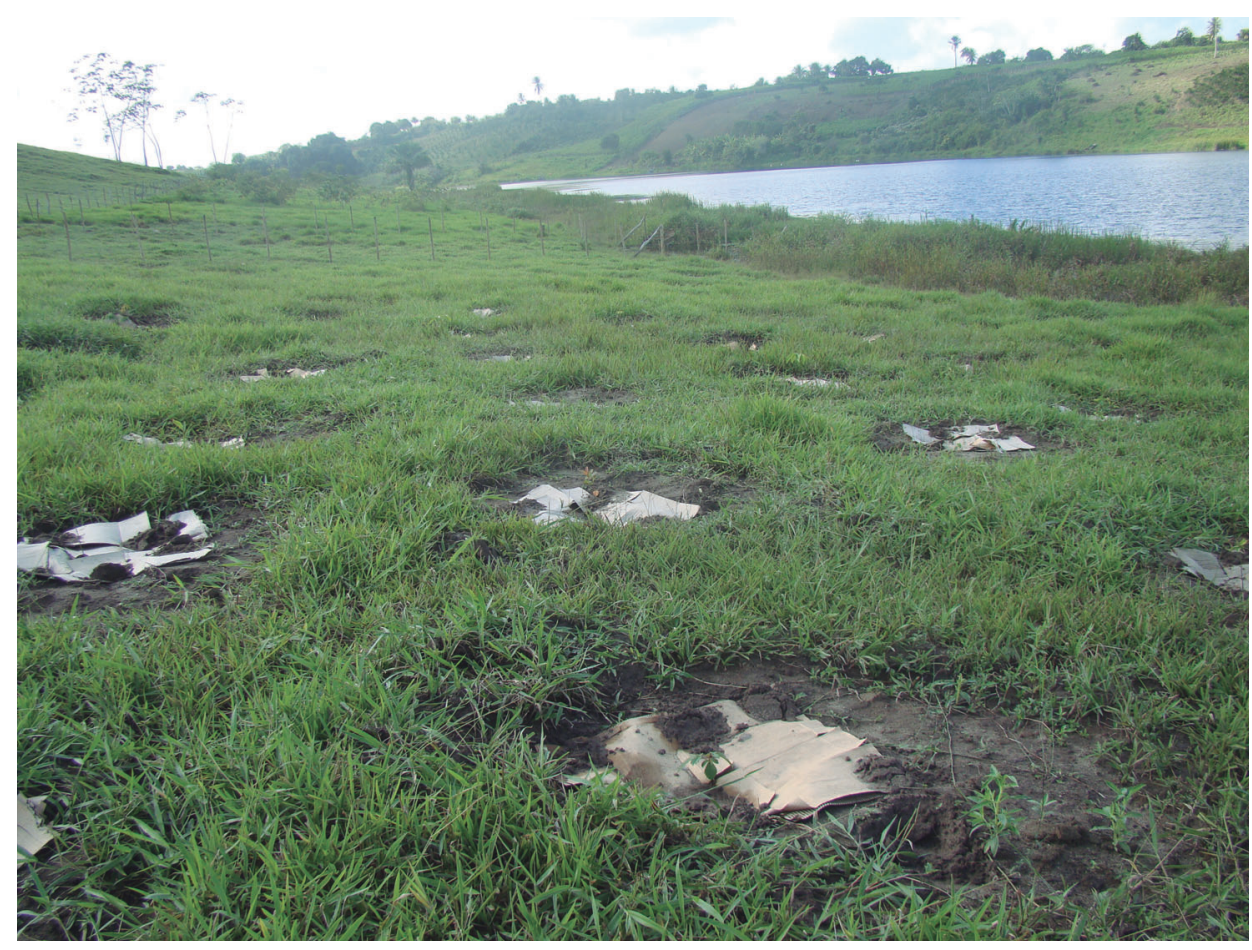


Dentre as operações realizadas na etapa de manutenção dos plantios, podemos destacar as limpezas ao redor da muda (com finalidade de eliminar plantas competidoras), esta limpeza pode ser manual com o uso de enxadas e química com aplicação de herbicidas. Destacamos também as operações de roçada, para rebaixar a vegetação vizinha das mudas plantadas, evitando competição por luz. Igualmente temos operações importantes de manutenção como o replantio, adubação de cobertura e colocação de cobertura morta. A seguir, descrevemos as operações mais comuns realizadas na fase de manutenção dos plantios de restauração ecológica.

\subsubsection{Capina manual}

Consiste na eliminação da vegetação competidora ao redor das mudas com uso de enxadas. A capina manual com enxadas pode ser realizada na área total, nas linhas de plantio, conjugadas ou não com uma roçada geral.

\subsubsection{Capina química}

Consiste na aplicação de herbicidas para eliminação da vegetação competidora presente ao redor das mudas. A capina pode ser realizada na área total (dependendo do tamanho das mudas e equipamento utilizado), nas linhas de plantio, nas entrelinhas do plantio, conjugadas ou não com uma roçada geral. Em muitos casos, a aplicação de herbicidas é proibida (como no caso de restauração de matas ciliares em reservatórios destinados a abastecimento doméstico de cidades), então é necessária a manutenção, através de capinas manuais com enxadas.

\subsubsection{Roçada}

A roçada consiste no rebaixamento da vegetação não arbórea competidora (principalmente por luz) existente na área de plantio. Esta roçada pode ser feita na área total, em linhas, de forma mecânica (através de foices), mecanizada (roçadeiras) ou química (aplicação de herbicidas). Normalmente, a vegetação existente é rebaixada para uma altura de aproximadamente 10 centímetros. 


\subsubsection{Coroamento}

É uma capina manual com retirada da vegetação competidora ao redor das mudas, normalmente, compreende uma área circular (coroa) com cerca de 50-60 cm de raio (100-120 cm de diâmetro) ao redor das mudas. Nesta área, a capina deve ser geral, eliminando toda vegetação existente. Esta operação pode ser manual (através do uso de enxadas) ou química (através da aplicação de herbicidas), sendo que a química exige que as mudas já possuam altura maior que $50 \mathrm{~cm}$, e o herbicida não atinja as folhas.

\subsubsection{Replantio}

Consiste na realização de um novo plantio das mudas (repasse) que deverá ser realizado em 30-60 dias, após o plantio inicial. O replantio deverá ser feito após avaliação do índice de mortalidade das mudas.

A experiência prática mostra que a média de mortalidade em plantios de nativas gira em torno de $5 \%$ de falhas, acima de $10 \%$ de falhas, é necessário identificar o fator gerador da mortalidade e resolver o problema (percentuais válidos para áreas de floresta ombrófila densa - Mata Atlântica).

Para o replantio, devem ser observados os mesmos parâmetros verificados para o plantio, principalmente em relação ao período chuvoso.

\subsubsection{Adubação de cobertura}

Consiste na aplicação complementar de adubo nas covas, após a operação e a adubação de plantio. Normalmente, esta adubação é feita durante as operações de manutenção (cerca de 120 dias após o plantio), quando as raízes das mudas já estão estabelecidas. Esta operação deve ser realizada após o coroamento ao redor das mudas e pode ser feita através da incorporação do adubo misturado ao solo, fazendo dois canais lado a lado da muda. Normalmente aplicamos de 150-250 gramas de adubo NPK ao redor das mudas, nesta adubação é recomendável uma adubação mais equilibrada em nutrientes ou com maior concentração de Nitrogênio e Potássio (Formulações NPK 10.0.30 ou 10.10.10, por exemplo). A adubação 
de cobertura deve também ser programada antecedendo ao período de chuvas, para melhor aproveitamento dos nutrientes do adubo pelas mudas.

\subsubsection{Colocação de cobertura morta}

Éuma operação que pode ser realizada após o plantio e revisada na manutenção. Consiste na colocação de resíduos de atividades de roçadas e coroamento ao redor das mudas, capim seco, por exemplo, nas coroas já limpas manualmente ou com herbicida.

Além de proteger a muda do aparecimento de vegetação competidora, ao redor das mudas, também mantém a umidade ao redor das mudas e reduz a necessidade de irrigação complementar e manutenção/coroamento ao redor das mudas.

\subsection{Monitoramento dos plantios}

A escolha de parâmetros, para monitoramento dos plantios de recuperação ambiental da Mata Atlântica, vai ser variável em função dos objetivos deste monitoramento. Em plantios experimentais, deve ser incorporado um maior número de variáveis para a mensuração e, em áreas de recuperação não experimentais, devem ser acompanhados os critérios ou indicadores mais simples de serem controlados periodicamente, escolhendo-se parâmetros que permitam comparar o desempenho de diferentes áreas em recuperação.

Como premissas básicas para o estabelecimento dos parâmetros de acompanhamento do desenvolvimento de plantios, temos de tomar como proposições básicas os objetivos definidos, no início dos trabalhos de plantio, isto é, a recuperação ambiental da floresta atlântica de determinada área e a recomposição da biodiversidade original, assim tomamos como base de referência o ecossistema original.

Um indicador é a medida de distância entre um objetivo ou a meta e aspectos de desempenho que devem ser avaliados, ou seja, indicadores são parâmetros que permitem avaliar atributos de um área ou processo, com objetivo de comparar tais resultados com resultados anteriores, metas ou objetivos preestabelecidos, ou ainda comparar áreas ou processos similares (FUNDAÇÃO PARA CONSERVAÇÃO E A PROTEÇÃO FLORESTAL DO ESTADO DE 
SÃO PAULO, 2004). Portanto os indicadores são parâmetros que indicam os resultados gerados pelas atividades realizadas.

Indicadores que podem ser utilizados:

- Mudas plantadas - para mudas plantadas, utilizamos critérios baseados no crescimento e desenvolvimento das plantas como: porte das mudas e plantio (altura total, altura do fuste, diâmetro do colo ou basal, DAP diâmetro a altura do peito e diâmetro da copa), riqueza do plantio (número de espécies plantadas), densidade (número de indivíduos por hectare).

- Regeneração natural (recrutamento) - número de indivíduos (não plantados) que surgem nas entrelinhas da área plantada, em recuperação. Pode ser amostrado em parcelas de área conhecida, distribuída na área, onde pode ser medida a regeneração de indivíduos novos (não plantados) que surgiram na área em recuperação.

- Diversidade da regeneração natural - diversidade de espécies da regeneração natural.

- Cobertura das copas - é medida pelo percentual de cobertura do solo pela vegetação (cobertura de copas) ou sombreamento.

- Diversidade de espécies florestais - mensurando tanto a diversidade de espécies plantadas, quanto a diversidade da regeneração natural (novos ingressos).

- Mortalidade - o índice de mortalidade, expresso em percentagem, é um bom indicador do sucesso do plantio realizado.

- Replantio - deverá ser computado e registrado o replantio realizado.

- Serrapilheira - podem ser medidos a profundidade e o peso da serrapilheira de determinada área (amostra). Também podem ser computados o peso e os nutrientes desta amostra, normalmente expressos em quilos por hectare (Kg/ha).

- Mato-competição - existência de gramíneas e de espécies invasoras.

- Ataque de pragas e doenças - presença de ataque de fungos, doenças e insetos na área recuperada. 
- Banco de sementes - indica o potencial de regeneração natural da área principalmente após distúrbio. Pode ser mensurado através de amostras coletadas em áreas conhecidas ou recolhidas no chão da floresta em recuperação.

- Chuva de sementes - compreende a queda de sementes na área em recuperação. Pode ser mensurada através da colocação de coletores dispostos na área.

- Monitoramento do componente fauna - o estudo da avifauna é hoje o parâmetro de fauna mais comumente utilizado. Em geral, fazemos o mesmo esforço de campo para comparar diferentes áreas (tempo de horas rede). Outros grupos de fauna também vêm sendo utilizados, principalmente mamíferos e formigas.

- Monitoramento do solo - esperamos que, com a implantação da vegetação, os solos também sofram mudanças com o passar do tempo. É um parâmetro interessante para monitoramento, principalmente para áreas de mineração onde, partindo de um solo geralmente exaurido, são grandes as mudanças do substrato ao longo do tempo. O solo pode ser monitorado através de sua composição química (teores de nitrogênio, fósforo, potássio etc.), de teores de matéria orgânica (um dos parâmetros que sofre maior transformação) e da composição física (densidade, porosidade e outros). Estes são bons parâmetros para monitoramento.

- Periodicidade - o monitoramento deverá ser feito periodicamente onde, em períodos regulares, são amostrados os mesmos indicadores selecionados na primeira amostragem de acompanhamento. Os parâmetros técnicos dos plantios são tomados como referência (espaçamento, diversidade de espécies utilizadas inicialmente, proporção de espécies entre os diferentes grupos ecofisiológicos). Quando da manutenção, obrigatoriamente, devem ser monitorados parâmetros como infestação de espécies invasoras, estado fitossanitário das mudas. 


\section{2}

\section{PRODUÇÃO DE SEMENTES E MUDAS FLORESTAIS}




\subsection{Suprimento de sementes}

opção por modelos de recuperação, que necessitam de se-
mentes para uso direto ou produção de mudas, pode ser um
grande problema para a região da floresta atlântica. Assim, em função da escala do projeto a ser executado, da área a ser recuperada, do tempo de execução do serviço e da existência de matrizes das espécies selecionadas, deve ser analisada a melhor alternativa para o suprimento de sementes: compra ou coleta própria na região de implantação do projeto.

Quando pensamos em compra de sementes, existem vários bancos de sementes, fornecedores de propágulos de floresta atlântica no Brasil, a maioria deles ligada a institutos de pesquisas e Universidades, e a algumas ONG's. As sementes, fornecidas por estes bancos, são geralmente acompanhadas de informações como percentagem de germinação, sistema de quebra de dormência e número de sementes por quilo, facilitando o planejamento da compra e da produção de mudas. As sementes provenientes destes bancos possuem como vantagem a garantia de qualidade. Entretanto, em função da própria demanda atual e da variabilidade da composição florística da floresta atlântica, nas diferentes regiões, a maioria das instituições não apresenta uma variedade de espécies suficientes para atender às necessidades de programas regionais de recuperação, que tenham como objetivo a recomposição da biodiversidade, específica para determinadas regiões. Observa-se também que muitos estados da costa atlântica não possuem sequer um banco de sementes.

Uma segunda alternativa é implantar um sistema próprio de coleta de sementes, tendo de formar uma equipe própria, ou terceirizada, de coletores. Neste caso, é importante primeiramente definirmos com quais espécies vamos trabalhar. Esta seleção é feita, como vimos, com base nos levantamentos florísticos e fitossociológicos e observações de campo, nos diversos estágios sucessionais da floresta, que queremos recuperar. Definidas as espécies, é necessário obtermos uma série de informações, como: existência de matrizes na região, época de frutificação, número de sementes por quilo, existência de dormência, melhor embalagem e condições para armazenamento. O conhecimento da fenologia das espécies (época de floração, frutificação e outras modificações) pode ser realizado em 
fichas apropriadas pela própria equipe de coleta de sementes. Geralmente, as informações citadas em literatura não vão ser exatas para sua região de trabalho, mas poderão nortear os primeiros passos, que se ajustam ao andamento dos trabalhos de fenologia. Devemos selecionar no mínimo dez matrizes de cada espécie selecionada (se possível mais), para a coleta de sementes, buscando uma variabilidade genética da espécie selecionada. Este número mínimo pode ser ampliado, em função da disponibilidade de matrizes. As matrizes são escolhidas, baseadas em características fenotípicas, ótimas para acelerar o processo de recuperação, devemos dar preferência à coleta de sementes na região onde estaremos fazendo a recuperação ambiental. De posse de todas estas informações, é possível planejar a coleta periódica (mensal, por exemplo), especificando qual espécie e qual quantidade de sementes a ser coletada pela equipe, de maneira a atender à necessidade de produção de mudas de seu programa. Este planejamento vai racionalizar os custos operacionais de coleta de sementes.

É importante, do mesmo modo, um bom treinamento da equipe de coleta de sementes, existe uma péssima tendência das pessoas coletarem sementes de árvores com características não desejáveis, pois são, geralmente, as de mais fácil acesso (porte baixo, galhos caídos). Desta maneira, estaríamos realizando um "pioramento" genético. Portanto é necessário especificar as características desejáveis para as árvores matrizes e ter uma participação de um técnico capacitado em sua seleção e marcação.

\subsection{Produção de mudas}

Considerando a diversidade florística e de ambientes presentes na floresta atlântica, um viveiro de mudas deve ser planejado, desde seu início, para produzir plântulas adaptadas às diferentes condições de campo encontradas. Em uma área de produção de mudas de floresta atlântica, devemos planejar o uso dos espaços conforme a demanda de mudas para o programa de recuperação. Normalmente, um viveiro deve possuir uma área de sombra (para produção de mudas para utilização em plantios de enriquecimento e para determinadas espécies que exigem esta condição na fase inicial), e uma grande área aberta exposta à luz solar direta, para produção de mudas aclimatadas para sobreviver nestas condições. 


\subsubsection{Escolha da área}

Para escolha de uma área de produção de mudas, temos de atender a algumas exigências básicas:

a) Água - em quantidade e qualidade suficiente para atender sua produção. Se utilizarmos água de cursos de água próximos, devemos saber se são perenes, se a vazão atende à demanda do futuro viveiro, além de conhecer a qualidade da água.

b) Acesso - deve ser de fácil acesso para facilitar o transporte das mudas para o campo, também deve ficar o mais próximo possível do local de plantio.

c) Topografia - não devemos escolher área que necessite de grandes obras de terraplanagem, a declividade deve variar entre $3-5 \%$. Devem ser evitados locais sujeitos à inundação, como margens de rios que transbordam anualmente.

d) Mão de obra - deve ser encontrada disponível nas proximidades da área do viveiro, reduzindo custos de transporte.

Um grande erro cometido por viveiristas é a produção de mudas em áreas extremamente sombreadas. As mudas produzidas, nestas condições, apresentam-se tenras e bonitas, porém, quando levadas para a área de plantio, têm grande mortalidade, pois não estavam ambientadas com a insolação direta e as altas temperaturas.

\subsubsection{Zoneamento}

Em um viveiro de nativas, devemos planejar os espaços, conforme demanda de mudas para o(s) programa(s) de recuperação que se pretende atender. Em áreas de floresta atlântica, na qual possuímos uma grande diversidade de condições ecológicas e de espécies, é interessante que, no viveiro, principalmente se for um viveiro permanente, tenha diferentes "ambientes" destinados à produção de mudas de diferentes condições ecológicas.

Existem basicamente dois tipos de viveiros - os permanentes e os temporários. Os permanentes são aqueles projetados para 
atender a programas de recuperação em grande escala, visto que é necessária a produção contínua de mudas por um longo período. Nestes casos, vale a pena aplicar maiores investimentos, incluindo uma área de sombra (recomenda-se o sombrite 50\%), área de produção de mudas com tubetes, além de galpão e depósitos para terra e compostos orgânicos. Já, em viveiros temporários, com duração prevista entre 1-2 anos, utilizamos em geral embalagens plásticas, e suas áreas de sombra são construídas com material da região (folhas de palmeiras, por exemplo).

Com referência à quantidade de mudas a serem produzidas, nesta fase, como em todo o processo de recuperação ambiental de áreas degradadas, devemos racionalizar e reduzir custos. Em função da área a ser recuperada, é preciso considerar o número de mudas necessário a ser produzido, computando percentuais de perda no viveiro e no campo (necessidade de replantio).

Normalmente, devemos possuir, em um viveiro de produção de mudas, as seguintes áreas:

a) Sementeiras - áreas onde são semeadas, principalmente propágulos de espécies que demoram em germinar. Atualmente existe uma grande tendência à realização do semeio direto, porque os custos de repicagem são eliminados, reduzindo o valor final da muda. As sementeiras devem ser utilizadas para sementes que demoram a germinar, como as de algumas palmeiras.

b) Área de repicagem - área de permanência temporária de mudas, com sombra de $50 \%$ ou mais, onde a plântula passa pela fase de pós-repicagem (passagem da sementeira para a embalagem plástica ou tubete). Nesta área de sombreamento mais forte, as mudas passam normalmente 1-2 semanas, conforme a espécie. Em viveiros temporários, pode ser utilizada a sombra de árvores bem densas para servir como área de pós-repicagem das mudas recém-repicadas.

c) Galpão - estrutura utilizada para depósito de terra e demais componentes dos substratos utilizados que não podem ser molhados para não atrapalhar as atividades de rotina do viveiro de produção de mudas. Em dias de chuva, os trabalhos - enchimento de embalagens - podem se concentrar nesta área. É interessante que seja anexado, a esta área, o almoxarifado. 
d) Depósitos - normalmente, temos depósitos separados para ferramentas (áreas de uso menos restrito, local em que os funcionários do viveiro têm acesso aos EPIs e ferramentas necessárias para o trabalho do dia a dia), adubos (utilizados quando necessário, é uma área que somente o encarregado do viveiro tem acesso e autoriza retirada) e, quando for o caso, as áreas de depósitos especiais para os agrotóxicos, que por ventura sejam utilizados no viveiro, devem ser armazenadas em lugares individuais e atendendo às condições estabelecidas nas legislações - federal, estadual e municipal -, específicas sobre o assunto.

e) Área de sombra - as áreas de sombra do viveiro estão presentes em qualquer tipo de viveiro de produção de mudas florestais (nativas e exóticas). São as áreas nas quais as mudas passam os primeiros meses de sua vida. Algumas mudas permanecem menos tempo nestas áreas (mudas de espécies pioneiras e secundárias iniciais), e outras podem ficar, nestas áreas, até o momento de plantio no campo, como no caso de mudas de espécies secundárias tardias e clímax, destinadas a plantios de enriquecimento - em ambientes já sombreados. Em viveiros permanentes, recomendamos que esta área seja coberta por sombrite $50 \%$, que atende bem à necessidade lumínica das mudas. Estes sombrites de vários níveis de sombreamento são, facilmente, encontrados no mercado e fornecem um nível de sombreamento uniforme em toda a área da casa de sombra. Eles são de fácil colocação e devem ser bem esticados para homogeneizar dentro da casa de sombra o nível de sombreamento, fornecido para as mudas produzidas. A FOTO 20 mostra uma casa de sombra coberta com sombrite $50 \%$, em que as mudas passam os primeiros meses da fase de produção, neste caso, foi utilizado o sistema de bandejas de chão. No caso de viveiros temporários, a área sombreada pode ser implantada, aproveitando a sombra de árvores já existentes ou coberta por folhas de palmeiras da região, reduzindo o investimento com a construção de uma área de sombra. 
FОTО 20 - Área de sombra, coberta com sombrite $50 \%$, onde as mudas passam os primeiros meses da fase de produção

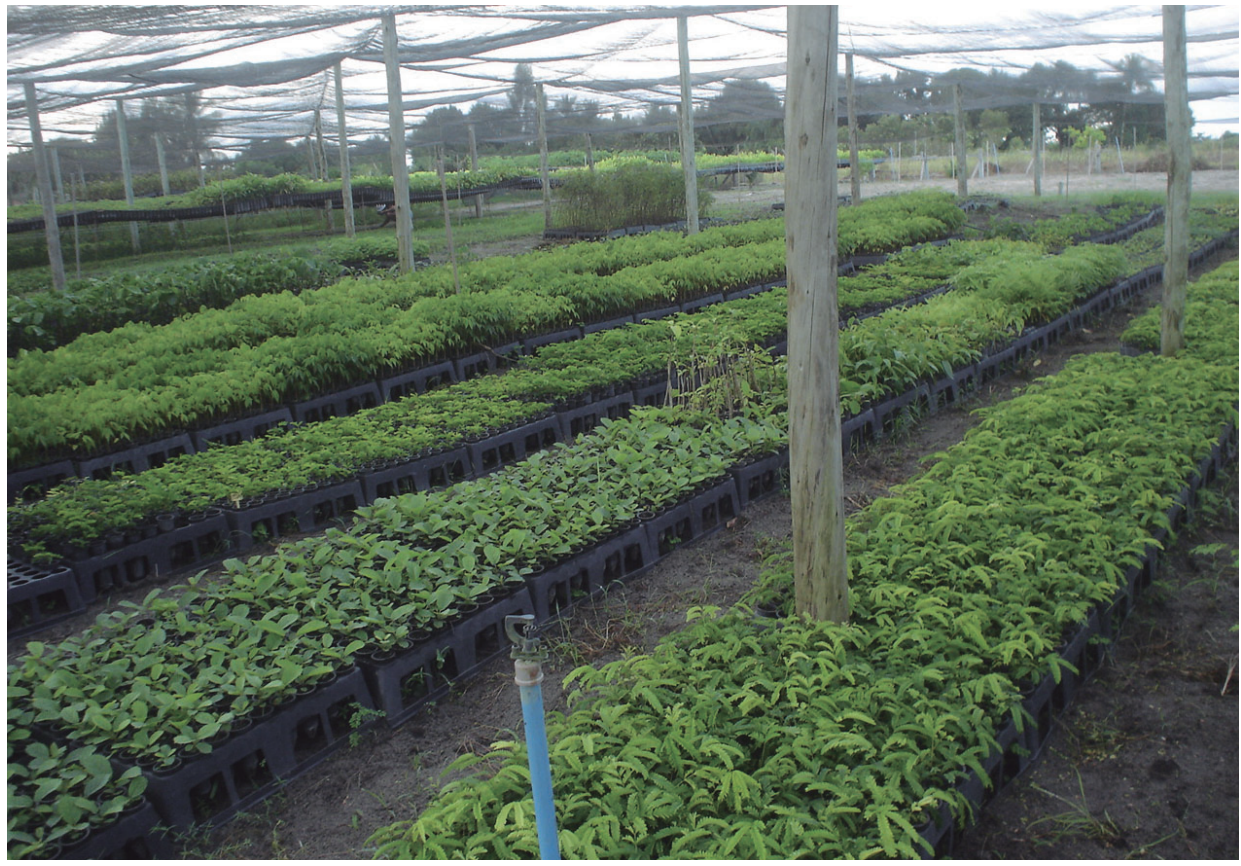

f) Área de rustificação - constitui-se em uma área onde as mudas estão expostas diretamente à luz solar direta, para produção de mudas que vão ser plantadas, nestas mesmas condições no campo. A área de rustificação é a última etapa do processo de produção de mudas florestais nativas. Principalmente, quando falamos de mudas de espécies pioneiras e secundárias iniciais, elas são mudas que, naturalmente, ocorrem em áreas abertas, portanto a área de rustificação se torna muito importante para aclimatação destas mudas.

Na FOTO 21, é mostrada uma área de rustificação, completamente sem sombreamento, onde as mudas recebem diretamente a luz do Sol, condição semelhante a que encontrarão após o plantio no campo. Nestas áreas de rustificação, as mudas sofrem uma redução gradual da irrigação fornecida, também visando maior adaptação às condições que serão encontradas no campo. Estas mudas rustificadas estão prontas para plantio e a resistir às condições que serão encontradas após o plantio.

g) Viveiro de espera - área onde as mudas são plantadas diretamente no solo, sistema muito utilizado para produção de mudas para arborização urbana. Neste local, as mudas podem atingir maior 
FOTO 21 - Aspecto de área de rustificação/aclimatação etapa final da produção de mudas que antecede expedição para plantio

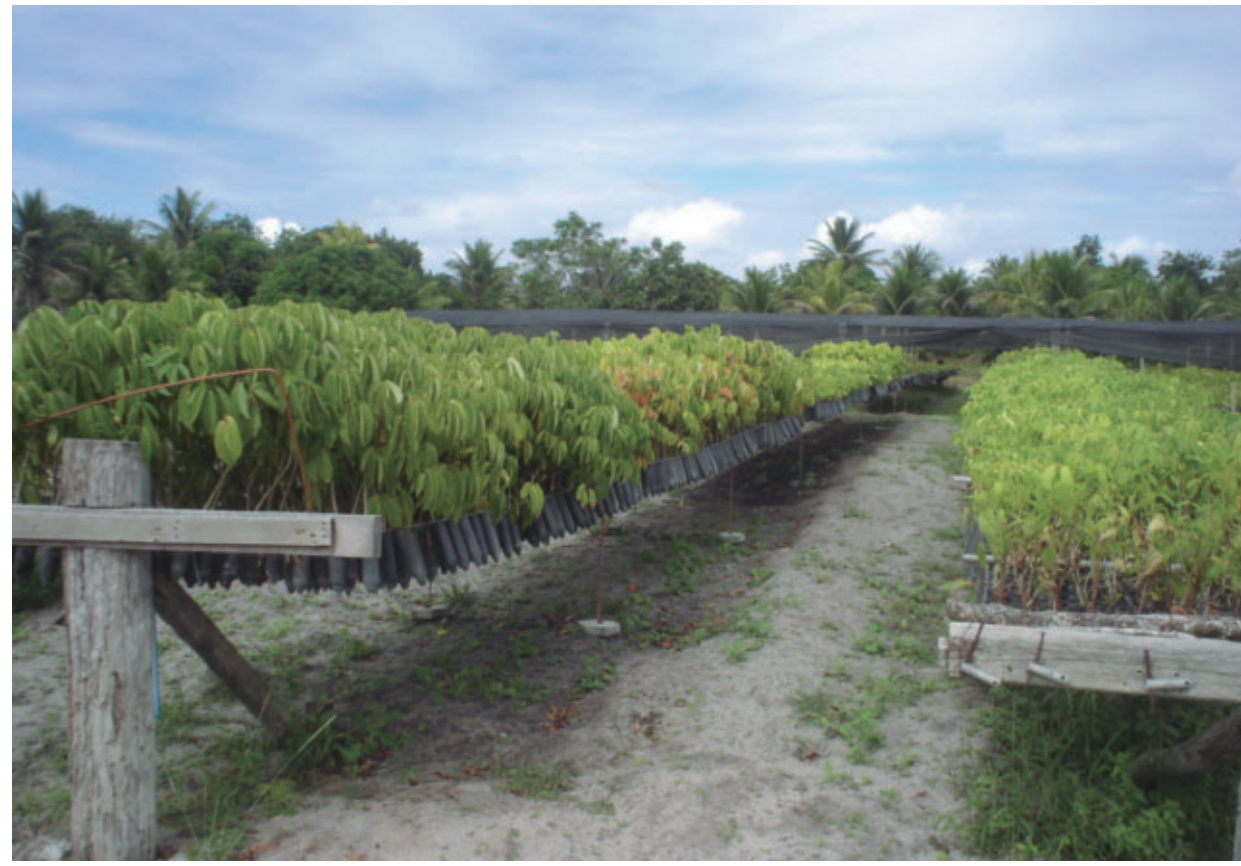

porte. Em alguns casos especiais, estas mudas poderiam atender à demanda para recuperação de áreas degradadas. Considerando o tempo de formação de mudas, cuidados especiais e custo da retirada, o valor final desta muda se torna alto.

\subsubsection{Recipientes para produção de mudas}

Temos hoje uma grande variedade de tipos de recipientes. Os mais utilizados são a tradicional sacola plástica e os tubetes de polietileno. As sacolas plásticas de tamanhos variados são bons recipientes, principalmente para mudas que necessitam de maior tempo para ficarem prontas para expedição. Elas apresentam como principais vantagens o fácil manuseio, a facilidade de encontrar no mercado e custo reduzido (em comparação com outros recipientes). Como desvantagens, citamos o grande risco de enovelamento de raízes, exigindo constante removimento das mudas de local.

Os tubetes - tubos duros de polietileno - são recipientes muito utilizados para produção de mudas florestais em grande escala. Existem, no mercado, tubetes de vários tamanhos, inclusive 
para produção de mudas de grande porte. Eles apresentam como vantagens o menor gasto de substrato (volume) em comparação com as embalagens plásticas, a facilidade de manuseio no viveiro. Os tubetes são recicláveis, não deixam resíduos na área de plantio, devido a seu tamanho reduzem o custo de transporte para a área de implantação e facilitam as operações de plantio. Outra grande vantagem sobre outros sistemas, é que, geralmente, comportam mais mudas por unidade de área de viveiro, necessitando menor área total de viveiro, reduzindo diversos custos como irrigação, substratos, mão de obra. Também é menor o risco de enovelamento de raízes, pois os tubetes possuem estrias que conduzem as raízes para baixo. A principal desvantagem é o investimento inicial, necessário para a adoção destes recipientes - construção de estaleiros (suportes), compra de bandejas e tubetes - o que é compensador apenas para viveiros permanentes (que vão produzir mudas por vários anos consecutivos). No mercado, encontramos tubetes de tamanhos variados (100 cc, $176 \mathrm{cc}, 290 \mathrm{cc}$, etc.) que devem ser adequados para as produções de mudas de variadas espécies nativas. Como regra geral, os tubetes maiores são utilizados para espécies que permanecem mais tempo no viveiro, e os tubetes pequenos, para espécies que ficam menor período na área do viveiro, normalmente espécies pioneiras. Na FOTO 22, podemos observar um tubetão para a produção de mudas nativas.

\subsubsection{Substratos}

Em função do recipiente escolhido, da quantidade e do tipo de muda a ser produzida, do sistema de propagação (sementes ou estacas), devemos definir o substrato que vamos utilizar. Geralmente, mudas florestais necessitam de substratos com um bom teor de matéria orgânica. Um bom composto orgânico (a base de esterco bovino e capim picado, por exemplo) é uma boa opção para compor até $100 \%$ do substrato. Outro componente importante é a terra, necessária para criar uma agregação do substrato, deve ser de textura argilosa e compor de $25 \%$ a $40 \%$ do substrato, este componente é indispensável no caso de embalagens plásticas. É recomendável que a terra utilizada seja proveniente de subsolo, evitando, assim, a presença de sementes de ervas daninhas. $\mathrm{O}$ restante do substrato pode ser preenchido com material orgânico decomposto como pó de 


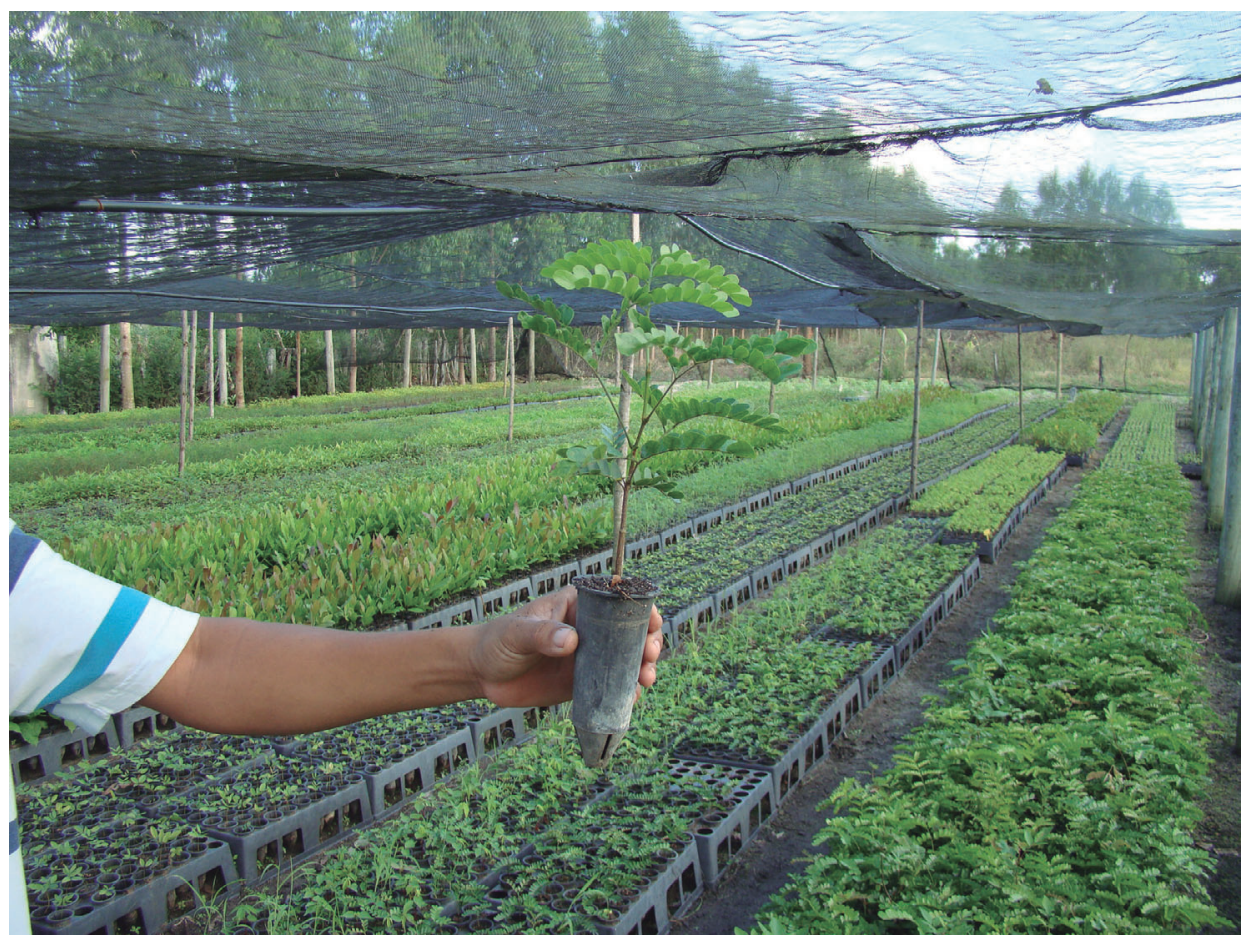

serra, casca de arroz (carbonizada), moinha (pó) de carvão, ou outro produto orgânico ou mineral que seja comum e barato na região do viveiro. Um importante substrato utilizado hoje, no Brasil, principalmente para a produção de mudas de eucalipto, é a vermiculita. Apesar do inconveniente do alto custo, é um substrato leve, livre de pragas e doenças, e retém bem a adubação mineral. Este substrato igualmente pode ser misturado com outros em proporções variadas. Em pequenos viveiros, recomendamos a utilização de compostos orgânicos, que podem ser produzidos na própria área do viveiro, e, considerando custo e benefício, fornecem bons resultados.

\subsubsection{Irrigação}

O sistema de irrigação deve ser planejado conforme tamanho e objetivo do viveiro. Para viveiros temporários, que têm como objetivos atender somente a recomposição de determinada área, em função do tamanho, a irrigação poderá ser realizada com regadores ou mangueiras. Já em viveiros permanentes, recomenda-se a 
implantação de um sistema fixo de irrigação, via aspersão, que vai facilitar e baratear, em longo prazo, esta operação.

As diferentes áreas existentes dentro de uma área de produção de mudas demandam diferentes tipos de aspersores e turno de rega. Normalmente sementeiras, ou áreas com embalagens recémsemeadas, necessitam de aspersão pulverizada (pequenas gotículas) com objetivo de não revolver o substrato que cobre as sementes. Já em áreas onde as mudas são adultas, aspersores grandes, que cobrem maior raio de irrigação podem ser utilizados com maior rendimento. Entretanto, visando facilitar a parte operacional e o planejamento, o ideal é se adotar um sistema único de aspersores. Quanto ao horário da irrigação, em dias ensolarados, o ideal é se aplicar uma irrigação pela manhã (o mais cedo possível) e outra, no final da tarde (quando o sol já está se pondo), evitando ao máximo a irrigação nas horas mais quentes e ensolaradas do dia. Em dias quentes e de grande insolação, recomenda-se 2 a 3 irrigações por dia; já, em dias chuvosos, em função da quantidade de precipitação, esta operação pode ser cancelada.

\subsection{Equipe de implantação e manutenção}

Considerando a especificidade dos serviços referentes à recuperação de áreas degradadas, em função da escala do projeto, é importante a formação de equipe multidisciplinar para elaboração e implantação desta tarefa. Desde a fase de reabilitação da estrutura - tratamentos no meio físico - do sistema, até a reintrodução das espécies vegetais e animais, uma série de profissionais de diversas áreas de conhecimentos são envolvidos. Também na fase de implantação, devido à especificidade das operações, desde o preparo do terreno até o plantio das mudas, para obtermos melhores rendimentos operacionais, é conveniente investirmos na formação de uma equipe especialista nestes serviços. Existem variações regionais nos rendimentos de operações de recuperação - limpeza de área, coveamento, adubação, combate à formiga e plantio - e uma equipe treinada pode reduzir em muito o custo final do projeto. Os serviços de manutenção, básicos para o sucesso do projeto, também devem ser realizados por equipes com experiência. Serviços de limpeza de área (roçadas e capinas) requerem conhecimento dos trabalhadores, que deverão saber identificar as espécies vegetais 
plantadas, além de conhecer a regeneração natural que não deve ser eliminada. Portanto, todos os trabalhadores, desde técnicos até operários, devem ser capacitados para desenvolver a contento seu papel.

Por se tratar de um projeto com muitas especificações desde coveamento, espaçamento até distribuição das espécies na área, é necessário o acompanhamento de um técnico capacitado durante todas as etapas de serviços de implantação e manutenção. No caso da existência de equipe de campo treinada, neste tipo de serviço, são necessárias apenas supervisões técnicas periódicas, variando conforme escala do projeto.

\subsection{Aspectos legais relacionados às mudas e sementes Florestais}

Para desenvolvimento de atividades, na área de coleta de sementes e produção de mudas florestais, existem procedimentos legais que devem ser seguidos. A lei básica que trata sobre este assunto é a Lei n. 10.711, de 05 de agosto de 2003, que dispõe sobre o Sistema Nacional de Sementes e Mudas e dá outras providências. Através desta lei, fica instituído, no Mapa, o Registro Nacional de Sementes e Mudas - RENASEM. Esta lei criou o Sistema Nacional de Sementes e Mudas, que tem como objetivo garantir a identidade e a qualidade do material de multiplicação e de reprodução vegetal produzido, comercializado e utilizado em todo o território nacional. Assim, todo produtor de sementes e mudas tem de possuir seu RENASEM.

Através da Instrução Normativa n. 24/2005, o Ministério da Agricultura e Pecuária (MAPA) fixa as diretrizes básicas a serem obedecidas na produção, comercialização e utilização de mudas, em todo o território nacional, visando à garantia de sua identidade $\mathrm{e}$ qualidade.

Especificamente para Produção, Comercialização e Utilização de Sementes e Mudas de Espécies Florestais, Nativas e Exóticas, temos a Instrução Normativa n. 56, de dezembro de 2011, que determina as normas para o produtor de sementes e mudas de espécies florestais. Hoje, além do registro obrigatório, existe a necessidade de termos um responsável técnico pela atividade (também inscrito no RENASEM), Engenheiro Florestal ou Engenheiro Agrônomo, com 
seu respectivo registro no CREA e Anotação de Responsabilidade Técnica (ART). Existem várias normas a serem seguidas e também a necessidade de apresentação de uma declaração anual da fonte de sementes de cada espécie, que pretenda produzir, assim como a produção estimada de mudas para cada espécie de acordo com o planejamento, esta informação será repassada ao órgão de fiscalização da Unidade da Federação (MAPA), onde a fonte de sementes esteja instalada, até 30 (trinta) de março do ano corrente.

Segundo determinado pelo RENASEM, as mudas, durante o processo de produção, devem estar identificadas, individualmente ou em lotes, com no mínimo o nome científico e nome comum da espécie e, quando for o caso, de cultivar, obedecida a denominação constante no RNC.

Quando se tratar de produção de sementes ou de mudas das espécies florestais para uso próprio (ser utilizadas apenas em propriedade de sua posse, sendo proibida a comercialização do material produzido), não é necessário o registro no RENASEM, porém deve ser declarada, anualmente, ao MAPA a produção de sementes ou de mudas destinadas para uso próprio. 


\section{3}

AÇÕES POSITIVAS PARA CONSERVAÇÃO E RESTAURAÇÃO DA MATA ATLÂNTICA NOS ESTADOS E MUNICÍPIOS 
$r_{t}^{t}$ onsiderando a extrema necessidade de conservação e restauração da Mata Atlântica, uma série de ações poderia ser tomada pelo poder público para garantir a conservação dos últimos remanescentes e a restauração das áreas importantes para conexão dos fragmentos florestais remanescentes. A união, os estados e os municípios podem atuar bem além do aspecto legal neste sentido.

As ações de conservação estão voltadas, principalmente, para a criação de Unidades de Conservação, hoje todos os grandes fragmentos florestais de floresta atlântica, em bom estado de conservação (em estágio avançado de regeneração e florestas primárias), deveriam constituir unidades de conservação. Vemos muitas áreas com mais de 1.000 hectares, que deveriam ser preservadas, ainda sofrendo ameaças. Podemos observar que, no domínio da Mata Atlântica, são poucos estes fragmentos (o que poderia gerar uma ação rápida de conservação, transformação em UC), e esta área ainda pode abrigar muitas espécies da flora e da fauna, incluindo espécies raras, endêmicas e ameaçadas de extinção.

Dentro das ações de conservação, observamos que a caça predatória ainda é uma ameaça constante para a conservação da Mata Atlântica, em especial, quando consideramos a grande interação/inter-relação entre flora e fauna neste Bioma. Mesmo nos dias de hoje, com toda tecnologia, comunicação, facilidade de acesso às informações, a caça ainda é tradição no meio rural das áreas do Bioma Mata Atlântica, praticamente, em toda sua extensão. Ações de fiscalização mais intensiva e de conscientização ambiental deviam ser intensificadas e planejadas para coibir e paralisar, completamente, estas ações de destruição da fauna da Mata Atlântica. Observamos que, mesmo dentro de Unidades de Conservação, esta prática é constante e ocorre no dia a dia. Em florestas particulares, de igual forma, tal prática é contínua, assim deveriam existir ações de fiscalização e conscientização ambientais em todos os níveis, fiscalizadas pelos órgãos responsáveis de nível federal (IBAMA), estaduais de meio ambiente e, principalmente, pelas secretarias de meio ambiente municipais. Um mapeamento dos pontos onde ocorrem as caçadas e um planejamento de ação para proibir definitavamente estas ações deveriam ter caráter de urgência.

Destacamos, neste item, a criação de Reservas Particulares de Proteção Natural (RPPN), que são unidades de conservação 
particulares, quando o proprietário, por iniciativa própria e espontânea, manifesta o interesse de destinar parte de sua propriedade para conservação ambiental. Estas iniciativas deveriam ter mais apoios que os previstos na legislação (praticamente somente isenção de ITR), visando incentivar os proprietários a criarem estas UC's particulares, a alternativa de pagamento de serviços ambientais (PSA) pode ser uma solução para dar maior incentivo à criação destas reservas particulares.

Outra forte ação que é necessária em todos os níveis de governo (federal, estadual e municipal) é a de restauração ecológica. Esta deve ser planejada, tomando como base, principalmente, o estudo da paisagem regional, de tal forma que permita a conexão dos principais fragmentos florestais do município, estado e união. O planejamento de paisagens e a disponibilidade de imagens de satélite de alta resolução são ferramentas que podem tornar esta ação mais eficiente. Uma importante iniciativa, neste sentido, é a implantação dos "Bancos de Áreas destinadas para Restauração Florestal", estas áreas cadastradas, através dos estudos de paisagem, realizados no município, assim como o interesse dos proprietários de terra, podem facilitar ações de restauração, principalmente, na acepção de conectar fragmentos florestais e formar corredores ecológicos, assim como restaurar matas ciliares importantes para conservação dos recursos hídricos.

Podemos observar, nos dias de hoje, várias iniciativas de financiamento e colocação de disponibilidade de recursos e financiamentos para ações de restauração ecológica e recuperação de áreas degradadas e perturbadas, assim torna-se cada vez mais necessário e urgente que todo município do domínio da floresta atlântica possa seu "Banco de Áreas Destinadas à Recuperação Ambiental". Este cadastro deve também conter potenciais produtores de mudas nativas e empresas com habilidade para executar plantios de restauração ecológica. A cadeia produtiva da restauração ecológica necessita ser formada em toda área de mata atlântica para que estas ações de restauração se tornem realidade e deixem de ser apenas marketing para se tornar algo e cientificamente real.

Neste planejamento ambiental de ações municipais, é muito importante conciliarmos as ações de intervenções necessárias nos ecossistemas (ações inevitáveis e necessárias para crescimento das cidades, implantação de grandes empreendimentos, obras sociais do governo etc.) com ações de conservação e recuperação ambiental, 
ou seja, instituir um grupo de ações práticas para compensação ambiental, todo dano ambiental causado resultaria em uma ação compensatória (já está legalmente previsto). Uma das estratégias que podem ser utilizadas nos municípios é a adoção de conjunto de práticas que podem vir a tornar condicionantes de todos os empreendimentos que serão implantados no território. Para empreendimentos onde se faz necessária a supressão de vegetação e é permitida legalmente esta prática (como exemplo, empreendimentos urbanísticos, em área urbana do município), podemos ter como condicionantes ambientais a obrigatoriedade da prática de resgate e salvamente de espécies da flora e fauna em todas as áreas, onde está previsto supressão de vegetação e outras intervenções sobre flora e fauna, assim como plantios de compensação em área igual ou maior a que está sendo suprimida. A associação de práticas de salvamento/resgate aos trabalhos de restauração ecológica é muito bem vinda, estes propágulos que normalmente iriam ser destruídos com a supressão de vegetação podem enriquecer áreas de restauração ecológica próxima à área de supressão. Vários propágulos também podem ser levados para viveiro de produção de mudas até ganhar condições de retornarem e serem reintroduzidos em plantios de restauração ou em áreas naturais similares.

A "Lei da Mata Atlântica" - Lei n 11.428, de 22 de dezembro de 2006 -, no seu artigo 7, apresenta condições que devem nortear as ações de proteção e de utilização do Bioma Mata Atlântica. Estas condições visam assegurar a manutenção e a recuperação da biodiversidade (vegetação e fauna) e o regime hídrico para as gerações presentes e futuras, bem como estimular a pesquisa e a difusão de tecnologias de manejo sustentável. Esta lei da Mata Atlântica institui a implantação dos planos municipais para Conservação e Recuperação da Mata Atlântica, dado que são abertas as possibilidades dos municípios atuarem diretamente na defesa, conservação e recuperação da vegetação nativa da Mata Atlântica. Os Planos Municipais para Conservação e Recuperação da Mata Atlântica (PMMA) tornam-se uma ferramenta fundamental para ações dentro do território do município. Várias ações, colocadas aqui, podem ser implementadas através das diretrizes dadas por este plano.

Iniciativas de incentivo de plantio de áreas florestais de Mata Atlântica devem se multiplicar, visando promover o retorno planejado da floresta atlântica. Citamos atitudes louváveis, neste 
sentido, como o programa Click Árvore da SOS Mata Atlântica, que já completa 13 anos de atividades de plantios de mudas de Mata Atlântica. No dia 01 de agosto de 2000, quando a Fundação SOS Mata Atlântica e o Instituto Vidágua lançaram o Clickarvore, o número de brasileiros que utilizavam a Internet era de aproximadamente 5 milhões de pessoas, e, no início do programa, tinha uma média de 2.000 acessos diários (FUNDAÇÃO SOS MATA ATLÂNTICA, 2000). Estes programas de recuperação em REDES têm crescido e são iniciativas importantes para envolver pessoas, cidadãos e multiplicar empreendimentos de restauração florestal. 


\section{REFERÊNCIAS}

ALMEIDA, D. S. Florística e estrutura de um fragmento de floresta atlântica, no município de Juiz de Fora, Minas Gerais. 1996. Dissertação ( Mestrado)- Universidade Federal de Viçosa, Viçosa, 1996.

\section{Caracterização da vegetação da área da Veracel}

Celulose. Eunápolis: Veracel Celulose S. A., 2005.

. Modelos de manejo e recuperação. Descrição e

avaliação. Eunápolis: Veracel Celulose S. A., 1997.

Observações de campo sobre espécies pioneiras

e secundárias. Eunápolis: [s.n.], 2007.

BARBOSA, L. M; MANTOVANI, W. Degradação ambiental: conceituação e base para o repovoamento vegetal. In: WORKSHOP SOBRE RECUPERAÇÃO DE ÁREAS DEGRADADAS DA SERRA DO MAR E FORMAÇÕES LITORÂNEAS. Anais ... São Paulo: SMA, 2000.

BAZZAZ, F. A.; PICKETT, S. T. A. Phyological Ecology of Tropical Succession: a comparative review. Annual review of ecology and systematics, vol. 11, p. 287-310, Nov. 1980.

BAWA, K. S.; PERRY, D. R.; BEACH, J. H. Reproductive biology of tropical lowland rain forest trees. I. Sexual systems and incompatibility mechanisms. American Journal of Botany, vol. 72, [n. 3?] , p.331-345, [Mar.?] 1985. Mensal.

BRASIL. Ministério do Meio Ambiente (MMA). Lei n. 11.428, de 22 de dezembro de 2006. Dispõe sobre a utilização e proteção da vegetação nativa do Bioma Mata Atlântica, e dá outras providências. Presidência da República, Casa Civil, Subchefia para Assuntos Jurídicos, Brasília, DF, 2006. Disponível em: <http://www.planalto.gov.br/ccivil_03/_ato2004-2006/2006/ lei/l11428.htm>. Acesso em: Mar. 2014. 
- Decreto n. 6.660, de 21 de novembro de 2008. Regulamenta dispositivos da Lei $\mathrm{n}^{\mathbf{0}}$ 11.428, de 22 de dezembro de 2006, que dispõe sobre a utilização e proteção da vegetação nativa do Bioma Mata Atlântica. Presidência da República, Casa Civil, Subchefia para Assuntos Jurídicos, Brasília, DF, 2008. Disponível em: <http://www.planalto.gov.br/ccivil_03/_ato20072010/2008/decreto/d666o.htm>. Acesso em: Ago. 2013.

. Lei n.12.651, de 25 de maio de 2012. Dispõe sobre a proteção da vegetação nativa; altera as Leis $n^{\underline{0 s}} 6.938$, de 31 de agosto de 1981, 9.393, de 19 de dezembro de 1996, e 11.428, de 22 de dezembro de 2006; revoga as Leis n ${ }^{\mathrm{os}} 4.771$, de 15 de setembro de 1965, e 7.754, de 14 de abril de 1989, e a Medida Provisória no ${ }^{0} .166$ 67, de 24 de agosto de 2001; e dá outras providências. Presidência da República, Casa Civil, Subchefia para Assuntos Jurídicos, Brasília, DF, 2012. Disponível em: <http://www.planalto.gov.br/ ccivil_03/_ato2011-2014/2012/lei/l12651.htm>. Acesso em: Ago. 2013 .

. Biodiversidade Brasileira. Brasília, DF: [MMA], 2002.

. Mata Atlântica. Patrimônio Nacional dos Brasileiros.

Brasília, DF: 2010.

BRAUN-BLANQUET, J. Sociologia vegetal. Estudio de las comunidades vegetales. Tradução A. P. L. Digilis y Grassi, M. Buenos Aires: Acme Agency, 1950.

BUDOWSKI, G. Distribuition of Tropical Americam Rain Forest Species in the Light of Successional Processes. Turialba, vol. 15, n. 1, p. 40-42, 1965 .

BURTON, P. J.; BALISKY, A. C.; COWARD, L. P.; CUMMING, S. G.; KNEESHAW, D. D. The Value of Managing for Biodiversity. The Forest Chronicle, vol. 68, n. 2, p. 225-237, Apr. 1992. 
CAMPELLO, E. F. C. O papel de leguminosas arbóreas noduladas e micorrizadas na recuperação de áreas degradadas (Parte I). In: CURSO DE ATUALIZAÇÃO EM RECUPERAÇÃO DE ÁREAS DEGRADADAS, 3., 1996, Curitiba. [Anais...?] Curitiba: [s.n., 1996?]. p. 9-16.

CARPANEZZI, A. A.; COSTA, L. G. S.; KAGEYAMA, P. Y.; CASTRO, C. F. A. Espécies Pioneiras para Recuperação de Áreas Degradadas: A observação em laboratórios naturais. In: CONGRESSO

FLORESTAL BRASILEIRO, 6., 1990, Campos do Jordão. [Anais...?] Campos do Jordão: [s.n.], 1990. p. 216-221.

CARPANEZZI, A. A.; LAURENT, J.-M. E. (coord.). Manual técnico da bracatinga (Mimosa scabrella Benth). Colombo: EMBRAPACNPF, 1988. 70 p. (EMBRAPA-CNPF. Documentos, 20).

CAPOBIANCO, J. P. Restam apenas 7,3\% da Mata Atlântica. Parabólicas, n. 40, p. 1, jun. 1998.

CHILD, G.; MACKINNON, J.; MACKINNON, K.; THORSELL, J. W. Managing protected. Areas in the Tropics. Gland: IUCN, 1986.

COMISSÃO INTERMINISTERIAL DO MEIO AMBIENTE (CIMA). Ministério das Relações Exteriores. Subsídios Técnicos para a elaboração do Relatório Nacional do Brasil para o CNUMAD. Brasília, DF: [s.n.] 1991. 172p.

CONSELHO NACIONAL DO MEIO AMBIENTE (CONAMA). Ministério do Meio Ambiente. Resolução n. oo1/86, de 23 de janeiro de 1986. Dispõe sobre critérios básicos e diretrizes gerais para a avaliação de impacto ambiental. Brasília, DF, [20-]. Disponível em: <http://www.mma.gov.br/port/conama/res/ res86/res0186.html>. Acesso em: Jul. 2014.

Resolução n. o10/93, de 1 de outubro de 1993.

Estabelece os parâmetros básicos para análise dos estágios de sucessão de Mata Atlântica. Brasília, DF, [20--]. Disponível em: <http://www.mma.gov.br/port/conama/res/res86/reso186. html>. Acesso em: Jul. 2014. 
. Resolução n. 388/2007, de 23 de fevereiro de 2007. Dispõe sobre a convalidação das resoluções que definem a vegetação primária e secundária nos estágios inicial, médio e avançado de regeneração da Mata Atlântica para fins do disposto no art. 40 § 10 da Lei no 11.428, de 22 de dezembro de 2006. Brasília, DF, [20--]. Disponível em: <http://www.mma.gov.br/ port/conama/res/res86/reso186.html>. Acesso em: Jul. 2014. CONSÓRCIO MATA ATLÂNTICA ; UNIVERSIDADE ESTADUAL DE CAMPINAS. Reserva da Biosfera da Mata Atlântica. Plano de Ação. Referências Básicas. 1992. 101p.

COSTA, L. G. S.; PINA RODRIGUES, F. C. M.; JESUS, R.M. Grupos ecológicos e a dispersão de sementes de espécies arbóreas em trecho da floresta tropical na Reserva Florestal de Linhares (ES). Revista Instituto Florestal, v. 4, n. 1, p. 303-305, Mar. 1992. (Parte 1).

DIAS, B. F .S. Estratégia mundial para a biodiversidade. Revista Instituto Florestal, v. 4, n. 1, p. 62-76, Mar. 1992. (Parte 1).

DIAS, L. E. O papel das leguminosas arbóreas noduladas e micorrizadas na recuperação de áreas degradadas (Parte 2). In: III CURSO DE ATUALIZAÇÃO EM RECUPERAÇÃO DE ÁREAS DEGRADADAS, 3., 1996, Curitiba. [Anais...?] Curitiba: [s.n., 1996?]. p.17-28.

EINLOFT, R; SOUZA, M. G.; COSTA, M. M.; GRIFFITH, J. J. Seleção de gramíneas e leguminosas utilizados para revegetação de taludes em sacos de aniagem e plantio de covas. In:

SIMPÓSIO NACIONAL DE RECUPERAÇÃO DE ÁREAS DEGRADADAS, 3., 1997, Ouro Preto. Anais... Ouro Preto: SOBRADE:UFV, 1997. p. 329-338.

ENGEL, V. L.; PARROTTA, J. A. Definindo a restauração ecológica: tendências e perspectivas mundiais. In: KAGEYAMA, P. Y.; OLIVEIRA, R. E. DE, MORAES, L.F.D. DE, ENGEL, V. L.; MENDES, F. B. G. (ed.) Restauração ecológica de ecossistemas naturais. Botucatu: Editora FEPAF, 2002. 
FOOD AND AGRICULTURE ORGANIZATION OF THE UNITED NATIONS (FAO). Global Forest Resourses Assesment. Rome: FAO, 2002. 140p.

FERRETTI, A. R. Modelos de plantio para a restauração. In: Galvão, A. P. M.; Medeiros, A. C. S. (org.). Restauração da Mata Atlântica em áreas de sua primitiva ocorrência natural. Colombo: Embrapa Florestas, 2002.

FINOL, U.V.H. Nuevos Parâmetros a Considerarse en el Análises estructural de las Selvas Virgines Tropicales. Revista Florestal Venezoelana, v. 14, n. 21, p. 29-42, 1971.

FORMAN, R. T. T.; GODRON, M. Landscape ecology. New York: John Wiley \& Sons, 1986.

FRANKEL, O. H.; SOULÉ, M. E. Conservation and evolution. Cambridge: University Press, 1981.

FUNDAÇÃO PARA CONSERVAÇÃO E A PROTEÇÃO FLORESTAL DO ESTADO DE SÃO PAULO. Secretaria do estado de Meio Ambiente. Recuperação florestal da muda à floresta. São Paulo: SMA, 2004.

FUNDAÇÃO SOS MATA ATLÂNTICA. Click árvore 10 anos plantando árvores e cidadania. São Paulo: [s.n.], 2010. (Textos de Maura Campanil).

GALINDO-LEAL, C.; CÂMARA, I. G. Mata Atlântica: biodiversidade, ameaças e perspectivas. São Paulo: Fundação SOS Mata Atlântica; Belo Horizonte: Conservação Internacional, 2005

GAlVÃO, A. P.; MEdEIROS, A. C. (ed.). Restauração da Mata Atlântica em áreas de sua primitiva ocorrência natural. Colombo: Embrapa Florestas, 2002. 
GANDOLFI, S. Estudo florístico e fitossociológico de uma floresa residual na área do aeroporto internacional de São Paulo, Município de Guarulhos, SP. 1991. Dissertação (Mestrado)- Universidade Estadual de Campinas, Campinas, 1991.

GRIFITH, J. J.; DIAS, L. E.; JUCKSCH, I. Novas estratégias ecológicas para a revegetação de áreas mineradas. In: SIMPÓSIO INTERNACIONAL, 1994, Curitiba. [Anais...??] Curitiba: FUPEF, 1994. p. 135-140.

GOMEZ-POMPA, A.; WIECHERS, L. Regeneración de los ecosistemas tropicales y subtropicales. In: GOMEZ-POMPA, A. et al. (ed.). Investigaciones sobre la regeneracion de selvas altas en Veracruz, México. México: Ed. Continental, 1979.

GONÇALVES, J. L. M.; FREIXÊDAS, V. M.; KAGEYAMA, P. V.; GONÇALVES, J. C.; DIAS, J. H. P. Produção de biomassa e sistema radicular de espécies de diferentes estágios sucessionais. Revista Instituto Florestal, v. 4, n. 1, p. 363-368, Mar. 1992.

GORCHOV, D. L.; CORNEJO, F.; ASCORRA, C.; JARAMILLO, M. The role of seed dispersal in the natural regeneration of rain forest after strip-cutting in the Peruvian Amazon. Vegetatio, vol. 107/108, p. 339-349, Jun. 1993

HOWE, H. F.; SMALLWOOD, J. Ecology of Seed Dispersal. Annual Review of Ecology and Systematics, [S.l.], v. 13, p. 201-228, 1982.

KAGEYAMA, P. Y. et al. Recomposição da vegetação com espécies arbóreas nativas em reservatórios de usinas hidrohelétricas da CESP. Piracicaba: IPEF, 1992. (Série Técnica).

KAGEYAMA, P. Y. Conservação "In situ" de recursos Genéticos de Plantas. Revista IPEF (Scientia Florestalis), n. 35, p. 7-35, abr. 1987. 
KAGEYAMA, P. Y.; CASTRO, C. F. A.; CARPANEZZI, A. A.

Implantação de matas ciliares: estratégias para auxiliar a sucessão secundária. In: SIMPÓSIO SOBRE MATA CILIAR, 1989, São Paulo. Anais ... Campinas: Fundação Cargill, 1989. p. 130-143.

KAGEYAMA, P. Y.; GANDARA, F. Biodiversidade e restauração de florestas tropicais. In: SIMPÓSIO SOBRE RESTAURAÇÃO ECOLÓGICA DE ECOSSISTEMAS NATURAIS, 1., 1999, Piracicaba. Anais... Piracicaba: IPEF, 1999.

. Recuperação de áreas degradadas. In: Rodrigues, R. R.; Leitão Filho, H. F. (coord.). Matas ciliares: conservação e recuperação. São Paulo: Edusp: FAPESP, 2000.

KRICHER, J. C. A tropical companion. Princeton: Princeton University Press, 1990.

INSTITUTO BRASILEIRO DO MEIO AMBIENTE E DOS RECURSOS NATURAIS RENOVÁVEIS (IBAMA). A Lei da Natureza. Lei de Crimes Ambientais. Brasília, DF: IBAMA, 1998.

. Manual de Recuperação de áreas Degradadas pela

Mineração: Técnicas de Revegetação. Brasília,DF: Ibama, 1990.

. Instrução normativa n. 4, de 13 de abril de 2011. Trata da necessidade de fazer cumprir a legislação ambiental, especialmente no que concerne aos procedimentos relativos a reparação de danos ambientais; estabelece exigências mínimas e nortea a elaboração de Projetos de Recuperação de Áreas Degradadas - PRAD ou Áreas Alteradas Elaboração de PRADs. 2011. Brasília, DF, 2011.

INSTITUTO BRASILEIRO DE GEOGRAFIA E ESTATÍSTICA (IBGE). Manual técnico da vegetação brasileira. Rio de Janeiro: IBGE ,1992. (Série Manuais Técnicos em Geociências).

INSTITUTO SOCIOAMBIENTAL (ISA). Plante as árvores do Xingu e Araguaia: Manual do Plantador. São Paulo: [s.n.], 2009. 
JANZEN, D. H. Ecologia vegetal nos trópicos. São Paulo: EDUSP, 1980.

JANZEN, D. H.; VASQUES-YANES, C. Aspects of tropical seed ecology of relevance to management of tropical forest widlands. In: GOMES-POMPA, A. et al. (ed.). Rain forest regeneration and management. Paris: UNESCO, 1991. (Man and the Biosphere Series, 6).

JESUS, R. M. Revegetação: da teoria à prática. Técnicas de implantação. In: SIMPÓSIO INTERNACIONAL RECUPERAÇÃO DE ÁREAS DEGRADADAS, 2., 1994, Curitiba. [Anais...?] Curitiba: FUPEF, 1994. p.123-134.

JOLY, C. A.; LEITÃO FILHO,H. F.; SILVA,S. M. O patrimônio florístico. In: CÂMARA, I. G. (coord.) Mata Atlântica. São Paulo: Editora Index: Fund. SOS Mata Atlântica, 1991.

JORDANO, P. Fruits and frugivory. In: FENNER, M. (ed.). Seeds, the ecology of regeneration in plant communities. Wallingford: CAB International, 1992.

LEAL FILHO, N. Caracterização do Banco de Sementes de três Estádios de uma sucessão Vegetal na Zona da Mata de Minas Gerais. 1992. Dissertação (Mestrado)- Universidade Federal de Viçosa, 1992.

LEITÃO FILHO, H. F. Ecologia da Mata Atlântica em Cubatão (SP). São Paulo: [s.n.] , 1993

MARTINS, S. V. Recuperação de matas ciliares. Viçosa: Ed. Aprenda Fácil, 2001.

. (ed.) Ecologia de florestas tropicais do Brasil. 2. ed. Viçosa: Ed. UFV, 2012. . (ed.) Restauração ecológica de ecossistemas degradados. Viçosa: Ed. UFV, 2012. 
MATTHES, L. A. Composição florística, estrutural e fenelogia de uma floresta residual do planalto paulista: Bosque dos Jequitibás. 1980. Dissertação (Mestrado)Universidade Estadual de Campinas, Campinas, 1980.

MELO, V. A. Poleiros artificiais e dispersão de sementes por aves em uma área de reflorestamento, no Estado de Minas Gerais. Dissertação (Mestrado)- Universidade Federal de Viçosa, Viçosa, 1997.

McARTHUR, R. H.; WILSON, E. D. The Theory of Island Biogeography. Princenton: Princenton University Press, 1967.

MITTERMEIER, R. A.; WERNER, T.; AYRES, J. M.; FONSECA, G. A. B. O país da diversidade. Ciência Hoje, v. 14, n. 81, p.20-27, 1992.

MOLCHANOV, A. A. Hidrologia florestal. [Lisboa?]: Fundação Calouste Gulbenkian, 1971.

MORELLATO, L. P.; LEITÃO-FILHO, H. F. Padrões de frutificação e dispersão na Serra do Japi. In: MORELLATO, L. P. (coord.). História Natural da Serra do Japi: ecologia e preservação de uma floresta no sudeste do Brasil. São Paulo: Editora da UNICAMP: FAPESP, 1992.

MORI, S. A.; BOOM, B. M.; FRANCE, E. T. Distribuition patterns and conservation of East Brazilian Coastal Forest Species.

Buttonia, vol. 33, n. 2, p. 233-245, Oct.-Dec. 1991.

NOGUEIRA, J. C. B. Reflorestamento heterogêneo com essências indígenas. Boletim Técnico, n. 24. São Paulo: Instituto Florestal, 1977.

PROGRAMA TEMÁTICO DE GESTÃO AMBIENTAL (PCNAT). II Oficina para Desenvolvimento de Técnicas e Métodos para o Planejamento de Paisagem. Eunápolis :PCNAT/IPEF/USP/ VERACEL 1998 
PIÑA-RODRIGUES, F. C. M.; REIS, L. L.; MARQUES, S. S. Sistema de plantio adensado para revegetação de áreas degradadas de Mata Atlântica: bases ecológicas e comparações de custo benefício com o sistema tradicional. Floresta e Ambiente, n. 4, p. 30-41, 1997.

POMPÉIA, S. L. Recuperação do ecossistema Mata Atlântica de Encosta. In: CONGRESSO FLORESTAL BRASILEIRO,6., 1990, Campos do Jordão. Anais ... Campos do Jordão: [s.n.], 1990. p. 262-282.

RANKIN-DE-MERONA, J. M.; ACKERLY, D. D. Estudos populacionais de árvores em florestas fragmentadas e as implicações para conservação in situ das mesmas na floresta tropical da Amazônia Central. Revista IPEF (Scientia Florestalis), n.35, p. 47-59, abr. 1987.

REDENTE, E. F.; McLENDON, T.; DePUIT, J. E. Manipulation of vegetation community dynamics for degraded land rehabilitation. In: SIMPÓSIO BRASILEIRO DE PESQUISA FLORESTAL, 1993. [Resumos...?] Belo Horizonte: [s.n.], 1993. p. 22.

REIS, A.; FANTINI, A. C.; REIS, M. S.; GUERRA, M. P.; DOEBELI, G. Aspectos sobre a conservação de biodiversidade e o manejo da floresta tropical Atlântica. Revista Instituto Florestal, n. 4, p. 169-173, mar. 1992. (Parte I).

REIS, A.; ZAMBORNI, R. M.; NAKAZONO, E. M. Recuperação de áreas degradadas utilizando a sucessão e as interações planta-animal. São Paulo: Conselho Nacional da Reserva da Biosfera da Mata Atlântica, 1999. (Série Cadernos da Reserva da Biosfera da Mata Atlântica, n. 14).

RODRIGUES, R. R.; MATHES, C. A. F.; TORRES, R. B. Metodologia usada na recomposição de mata de planalto após ocorrência de fogo, Santa Elisa, Campinas/SP. In: CONGRESSO DA SOCIEDADE DE BOTÂNICA DE SÃO PAULO,1990 Campinas. Resumos... [Campinas: s.n.], 1990. 115. 
SALIS, S. M. Composição florística e estrutura de um remanescente de mata ciliar do Rio Jacaré-Pepira, Brotas (SP). 1990. Disertação (Mestrado)- Universidade Estadual de Campinas, 1990.

SANTARELLI, E.G. Produção de mudas de espécies nativas para florestas ciliares. In: RODRIGUES, R.R.; LEITÃO-FILHO, H. F. (ed.). Matas ciliares: conservação e recuperação . São Paulo: EDUSP: FAPESP, 1989.

SÃO PAUlO (Estado). Secretaria do Meio Ambiente. A Serra do Mar: degradação e recuperação. São Paulo: [s.n.] 1990. (Série Documentos).

SILVA, W. R. Interação planta-animal na restauração. In: SIMPÓSIO SOBRE RESTAURAÇÃO ECOLÓGICA DE ECOSSISTEMAS NATURAIS, 1., 1999, Piracicaba. Anais... Piracicaba: IPEF, 1999.

SILVA, A. F.; LEITÃO FILHO, H. F. Composição florística e estrutura de um trecho da Mata Atlântica de Encosta no Município de Ubatuba (São Paulo, Brasil). Revista Brasileira de Botânica, n. 5, p. 43-52, 1982. (Trimestral).

SILVA FILHO, N. L. Recomposição da cobertura vegetal de um trecho degradado da Serra do Mar, Cubatão - SP. Campinas: Fundação Carril, 1988.

SIMÕES, L. L.; LINO, C. F. Sustentável Mata Atlântica: a exploração de seus recursos florestais. São Paulo: Editora SENAC, 2002.

SOUZA, A. L.; LEITE, H. G. Manejo Florestal. Apostila do curso de Manejo Florestal UFV - Viçosa, 1993. 147p.

SOUZA, A. L.; SILVA, E. Manejo para conservação da biodiversidade em fragmentos florestais. Informativo SIF, n.o2, p. 2, 1994 . 
SWAINE, M. D. (ed.) The ecology of tropical forest tree Seedlings Paris: UNESCO: The Parthenon Publishing Group, 1995. (Man and Biosfere Series, 18.),

SWAINE, M. D.; WHITHMORE, T. C. On the definition of ecological species groups in tropical rain forest. Vegetation, vol. 75, p.81-86, 1988.

VALCARCEL, R.; D’ALTÉRIO, C. F. V. Medidas físico-biológicas de recuperação de áreas degradadas: avaliação das modificações edáficas e fitossociológicas. Floresta e Ambiente, v. 5, n. 1, p. 68-88, jan-dez. 1998.

VERACEL. Programa Mata Atlântica. Eunápolis: Veracel Celulose Ltda., 2005. 52p.

VIANA, V. M. Biologia e Manejo de Fragmentos de Florestas Naturais. In: CONGRESSO FLORESTAL BRASILEIRO, 6., 1991, São Paulo. Anais... São Paulo: SBS, 1990. p. 113-118. v.1.

VIANA, V. M. Conceitos sobre Sistemas Agroflorestais. In: DOSSIÊ sobre Sistemas Agroflorestais no Domínio da Mata Atlântica. Linhares: [s.n.], 1991.

WHITMORE, T.C. Forest dynamics and questions of scala. In: HADLEY, M. (ed.). Rain Forest Regeneration and Manegement. Paris: Int. Union of Biol. Sci., 1988. 


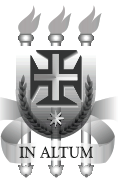

IMPRENSA UNIVERSITÁRIA

Impresso na gráfica da Universidade Estadual de SANTA CruZ - Ilhéus-BA 